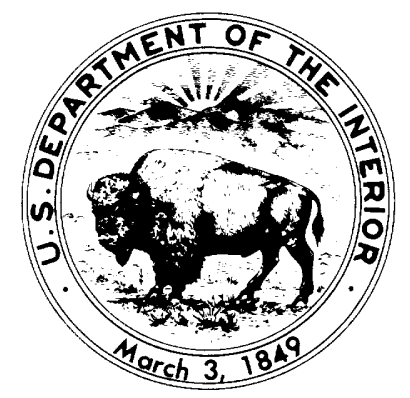

\title{
FIELD SURVEYING AND TOPOGRAPHIC MAPPING IN ALASKA: 1947-83
}





\section{FIELD SURVEYING AND TOPOGRAPHIC MAPPING IN ALASKA: 1947-83}

By Robert C. Foley

\section{U.S. GEOLOGICAL SURVEY CIRCULAR 991}

A chronological review of surveying activities in Alaska from 1947 to 1983, including a brief description of camp life and some of the hardships and unusual experiences encountered 


\section{DEPARTMENT OF THE INTERIOR DONALD PAUL HODEL, Secretary \\ U.S. GEOLOGICAL SURVEY \\ Dallas L. Peck, Director}

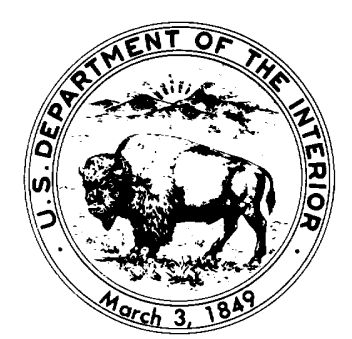

Free on application to the Books and Open-File Reports Section, U.S. Geological Survey, Federal Center, Box 25425, Denver, CO 80225 


\section{Foreword}

Field surveying and mapping in Alaska over the years have provided a unique opportunity for many not-so-ordinary experiences worthy of being recorded before they are lost forever. The author, Robert C. Foley, has provided a historical recounting of the Geological Survey's Alaska field mapping activities and related experiences during the period 1947-83. Robert retired from the Rocky Mountain Mapping Center in 1980 after 36 years of Federal service, including 16 field seasons spent in Alaska. He was hired as a reemployed annuitant until 1983. Robert is unquestionably this mapping center's foremost Alaska mapping authority and was awarded the Department of the Interior's Superior Service Award in 1983 in recognition of his contributions.

Although some editorial changes have been made to improve the organization and flow of this publication, we have purposely avoided major changes in wording to preserve the author's style in recounting these events.

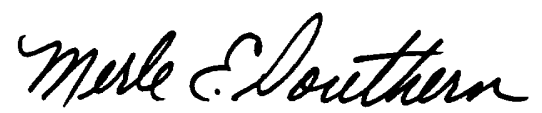

Merle E. Southern

Chief, Rocky Mountain Mapping Center U.S. Geological Survey

Denver, Colorado 



\section{Contents}

\begin{tabular}{|c|c|c|c|}
\hline & Page & & Page \\
\hline Foreword & iii & Mapping activities, 1947-83-Continued & \\
\hline Abstract & 1 & $1969 \ldots \ldots$ & 25 \\
\hline Introduction & 1 & 1970 & 25 \\
\hline Mapping activities before 1947 & 1 & 1971 & 26 \\
\hline Mapping activities, 1947-83 & 2 & 1972 & 26 \\
\hline 1947 & 2 & 1973 & 27 \\
\hline 1948 & 3 & 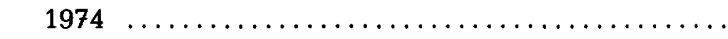 & 28 \\
\hline (n. & 5 & $1975 \ldots \ldots \ldots$ & 28 \\
\hline$\ldots \ldots, \ldots, \ldots, \ldots, \ldots, \ldots$ & 7 & $\ldots \ldots \ldots \ldots \ldots$ & 28 \\
\hline 1951 & 8 & 1977 & 28 \\
\hline ......... & 9 & ............... & 29 \\
\hline 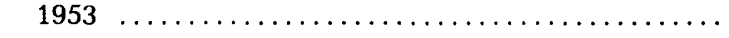 & 10 & 1979 & 30 \\
\hline 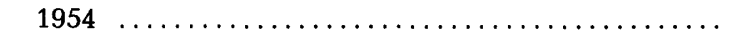 & 11 & 1980 & 31 \\
\hline 1955 & 13 & 1981 & 31 \\
\hline 1956 & 15 & 1982 & 32 \\
\hline 1957 & 18 & 1983 & 32 \\
\hline$\ldots \ldots \ldots$ & 19 & Summary & 34 \\
\hline 1959 & 20 & Selected references & 36 \\
\hline 1960 & 21 & Appendix A-Alaska project campsites ....... & 38 \\
\hline 1961 & 22 & Appendix B-Alaska field crews & 39 \\
\hline 1962 & 22 & Appendix C-Alaska geographic features named for & \\
\hline 1963 & 22 & U.S. Geological Survey employees & 43 \\
\hline .............. & 23 & Appendix D-History of explorations and surveys, by & \\
\hline 1965 & 24 & Alfred H. Brooks (1906) & 45 \\
\hline 1966 & 24 & Appendix E-Surveying and mapping in Alaska, by & \\
\hline 1967 & 24 & Gerald FitzGerald (1951) & 75 \\
\hline 1968 & 25 & & \\
\hline
\end{tabular}

\section{Plate}

Map showing the location of project campsites

\section{Figures}

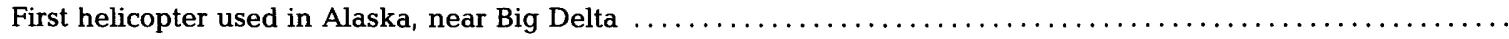

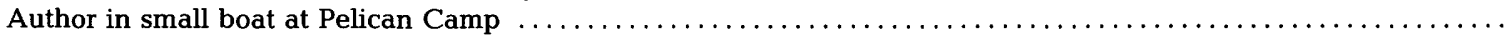

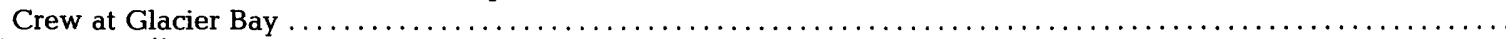

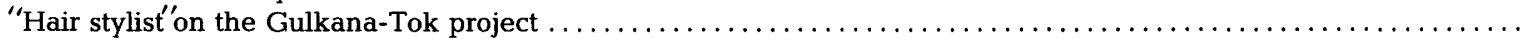

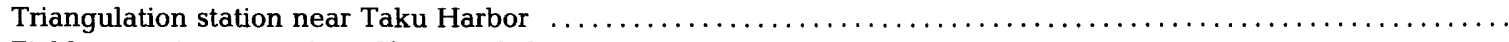

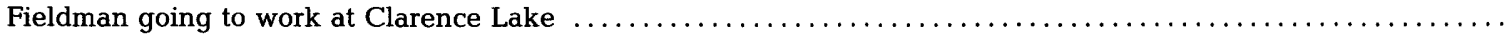

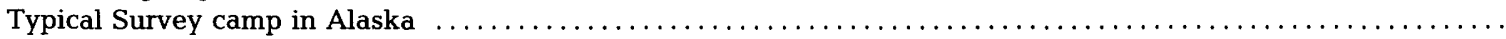

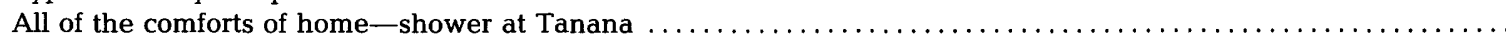

Inserting glass plate in phototheodolite

Bell Model 476 helicopter after a bad landing near Northway

Changing damaged helicopter blades onsite, Gardiner Creek 


\section{Figures-Continued}

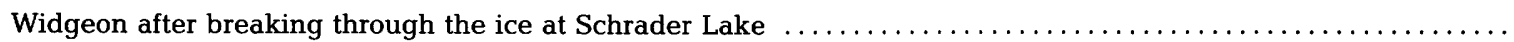

Preparing to haul fuel off Schrader Lake to designated areas for helicopter caches $\ldots \ldots \ldots \ldots \ldots \ldots \ldots \ldots \ldots$

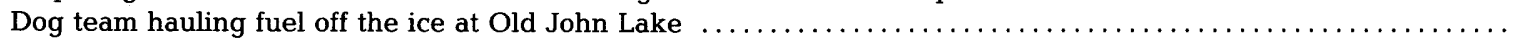

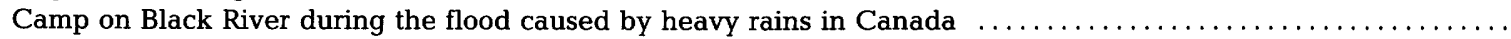

Driving the Alcan Highway to Alaska

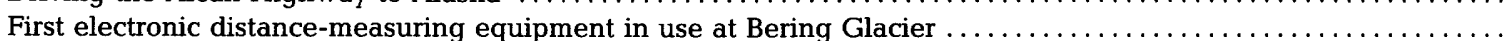

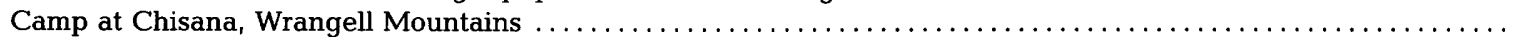

R. E. Isto, the Survey's first Alaska Resident Engineer, on the Juneau Ice Cap $\ldots \ldots \ldots \ldots \ldots \ldots \ldots \ldots \ldots$

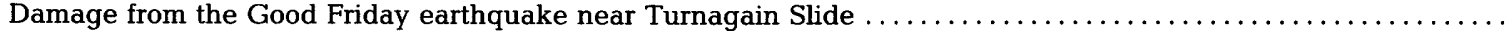

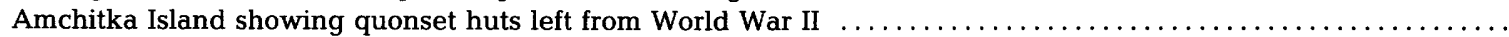

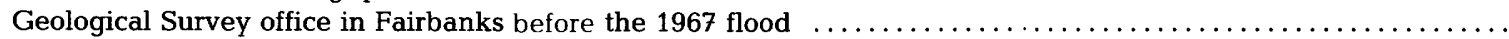

Hiller 12-E helicopter, electrotape, and signal light on a map control point south of Bettles $\ldots \ldots \ldots \ldots \ldots \ldots \ldots$

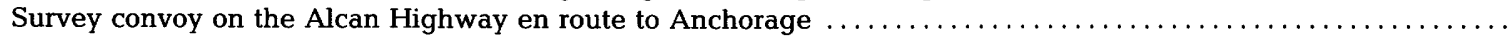

Satellite tracking instrument used for establishing geodetic positions from satellites $\ldots \ldots \ldots \ldots \ldots \ldots \ldots \ldots$

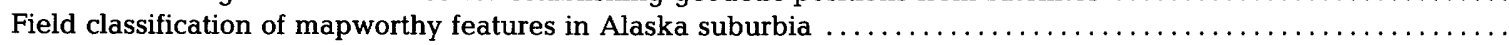

Mount McKinley as seen through the clouds from north of Talkeetna . .

Walter Cronkite inspecting equipment during filming of Survey operations for "Universe"

TV series

Satellite tracking receiver set up near pumping station as part of 1983 control tie work along

Readying the Tiloma for a day's work near Juneau 


\title{
Field Surveying and Topographic Mapping in Alaska: 1947-83
}

\author{
By Robert C. Foley
}

\begin{abstract}
The U.S. Geological Survey's earliest presence in Alaska dates back to 1889. A decade later, topographic mapping became an integral part of the Geological Survey's Alaska program, mostly as reconnaissance-type mapping and special-purpose mapping of specific sites. It was not until after World War II that the Survey's Alaska topographic mapping efforts began to bear fruit.

This circular retraces surveying and topographic mapping by the Geological Survey in Alaska from 1947 to 1983 and describes camp life and some of the unusual happenings involved in working in virtually uninhabited country, adverse weather, and difficult terrain. A year-by-year recap of activities documents the transition from early small-scale mapping efforts to more accurate and detailed 1:63,360scale mapping for Alaska except the Aleutian Islands and isolated islands in the Bering Sea. Recent 1:25,000-scale metric mapping and the preparation of orthophotographs and special mapping efforts for other Government agencies also are recounted.
\end{abstract}

\section{Introduction}

As early as 1889, U.S. Geological Survey personnel were sent to Alaska as members of various scientific expeditions. It was not until 1898 that an organized and systematic topographic mapping effort became an integral part of the Geological Survey's Alaska program. This circular describes the field efforts expended by the Geological Survey from 1947 to 1983 in surveying and topographic mapping in Alaska, with emphasis on Alaska camp life and some of the hardships and unusual happenings not normally encountered in field mapping activities in the lower 48 States.

Although attention is focused on the Geologi-

\footnotetext{
Any use of trade names and trademarks in this publication is for descriptive purposes only and does not constitute endorsement by the U.S. Geological Survey.
}

cal Survey's presence in Alaska, other Federal and State agencies were engaged in surveying, mapping, and charting activities in Alaska. The cooperative spirit and support that existed among these agencies made a difficult mapping task somewhat easier.

Much of the early exploration work and mapping effort in Alaska has been ably documented by Alfred H. Brooks in The Geography and Geology of Alaska (p. 104-132 are reproduced as Appendix D in this circular) and by Gerald FitzGerald in Surveying and Mapping in Alaska (reproduced as Appendix E).

The intent of this circular is not only to document Alaska field activities during the period from 1947 to 1983 , but to preserve something of the past before all personal contact with the fieldmen involved is lost. The Geological Survey workforce has gone through a transition of sorts, where most of the older contingent of Alaska field personnel have assumed other duties or retired. This circular presents a chronological recap of the work of this seasoned group of fieldmen and something of their Alaska experiences-the favorite stories and anecdotes that could conceivably be lost forever.

Photographs are from the Survey's collection and from private sources. Listings of project campsites, crew members, and Alaska geographic features named for Survey employees are included as appendixes to provide additional background information.

\section{Mapping Activities Before 1947}

Mapping in Alaska from 1890 to 1941 consisted of reconnaissance and special maps. Re- 
connaissance maps were made along the transportation corridors and main rivers. Special maps were made for mining areas, townsites and powersites, and for geologic studies. Many of these mapping expeditions were carried out using packhorses, dog teams, and river boats. It was not until the 1920's that airplanes were used to any extent.

Panoramic photography was first available in the early 1900 's to aid in mapping. In 1926, the U.S. Navy began acquiring aerial photography with a three-lens camera. Eventually all of southeastern Alaska was covered with this type of photography.

During the 1930's, considerable photographic coverage was obtained over the territory. Most of this photography was taken with hand-held cameras, and the resulting photographs were oblique. During the 1940's, the U.S. Air Force covered most of the territory with trimetrogon photography. The military also obtained vertical photography over the Aleutian Islands and compiled 1:25,000-scale maps of the strategic areas in the Aleutians by photogrammetric methods. During World War II, the Air Force established astronomic positions around the territory. Most of these positions were at villages that had landing strips. By using the astronomic positions and existing National Geodetic Survey horizontal control, the templet laydowns were controlled to make the planimetric bases for the 1:250,000-scale reconnaissance map series.

The Survey had only a few field parties in Alaska during World War II. However, in 1945 and 1946, several field parties were sent to Alaska to work on special maps and to establish horizontal control around Umiat for the Naval Petroleum Reserve No. 4.

The field season of 1946 was the last year that Geological Survey crews were sent to Alaska from the national headquarters offices in Washington, D.C. The Rocky Mountain Region office was established in Denver, Colorado, at the Federal Center in July 1946, and the Alaska Branch was transferred from Washington, D.C., to Denver. The four field parties in Alaska during the 1946 season reported to the new Rocky Mountain Region office in fall 1946. During fall and winter 1946 and spring 1947, Alaska materials were shipped to Denver from Washington, D.C.
Mapping Activities, 1947-83

\section{7}

In 1947, the first field crews from the Denver office were sent to Alaska. Seven men were selected to work on small one-man projects. Three projects were in southeastern Alaska at Heceta Island, Chichagof Island, and Stikine River near Wrangell (see map in pocket), and three were at Homer, Healy, and Cantwell. One man was detailed to Fairbanks to act as liaison to the Air Force, which was obtaining vertical photography in priority areas.

Planimetric bases were made for the three projects in southeastern Alaska using old 1926 and 1929 Navy three-lens rectified photographs. Sufficient National Geodetic Survey horizontal shore control existed to make the planimetric bases with metal templet laydown. The existing control was identified on the photographs in the office from the field descriptions. The Navy photographs were annotated in the office delineating the ridges, roads, drainage, and any other information that might be useful to the fieldman. This information was transferred to the base made from the templet laydown using vertical and oblique sketchmasters. After the planimetric information was transferred from the photographs to the bases, the bases were reduced to scale and mounted on metal sheets to fit an 18- by 24 -inch planetable board. The fieldman used these metalmounted planimetric sheets for planetable intersection work to establish elevations by vertical angles using a high-standard alidade. After the fieldwork was completed and elevations were established on ridges, drains, peaks, saddles, and anything else that could be identified, the contours were hand sketched. However, because of the availability of new photographs and stereoplotting equipment that changed mapping methods over the next 2 years, very little of this planetable work was published.

The fieldwork at Cantwell, Healy, and Homer was accomplished by establishing elevations on photoimages on existing vertical photographs. Utilizing this field control, the maps were compiled in the office by using the Mahan plotter and photoalidade. The fieldwork 
was completed on all the projects in September, and the crews returned to Denver.

Incidental to this work, but of great significance to future Alaska mapping, was an experimental project conducted late in 1947 at Canon City, Colorado, to test whether a helicopter would be practical for transporting men and survey equipment. The test was conducted for a week and had favorable results. In spring 1948, a helicopter was contracted to transport men and instruments for triangulation surveys on a project in western Colorado.

\section{8}

The field season of 1948 began a new era in Alaska field operations. The Air Force and the Navy were acquiring new vertical photography. This was the first season that 1:63,360-scale standard quadrangle mapping projects were initiated. Projects in the interior of Alaska had new vertical photographs available, but the southeastern Alaska projects still had the old 1926 and 1929 Navy rectified photographs.

Photocontrol was planned on the new vertical photography to comply with the requirements for compiling the maps on the multiplex plotting instruments. Metal templet laydowns were used to make planimetric bases from the 1926 and 1929 Navy photographs for the southeastern Alaska projects. Before the field season was over, however, the Navy had flown new vertical photography covering all southeastern Alaska, which was made available to the field parties. Most of the planetable-intersected points were transferred to the new aerial photographs, and the existing National Geodetic Survey shore control was photoidentified. This enabled the southeastern Alaska projects to be compiled by multiplex instrumentation along with the other projects.

During the last week of April, 24 men from Region headquarters left Denver on a private pullman car for Seattle, Washington. After a week in Seattle purchasing camp supplies, groceries, tents, and other miscellaneous items, the crews boarded the Alaska Steamship Liner Aleutian for the trip up the inside passage to Alaska. The crews debarked at various ports from Ketchikan to Seldovia to start their assigned projects. From the time the crews left Denver until the field camps were built, it was approximately a month before fieldwork was started.

Based on the results of the successful helicopter test at Canon City and the actual field operations in western Colorado, two helicopters were contracted for use in Alaska. The helicopters arrived in Alaska about June 20 from Yakima, Washington. One helicopter was assigned to the project on Chichagof Island, and the other helicopter was assigned to the crew at Big Delta. Both helicopters were stripped down to the bare essentials to carry more payload and to be able to land at higher elevations. Neither helicopter had a bubble or cabin, but the one at Chichagof did have a small windshield that helped some, especially when it was raining. Raindrops felt like small buckshot when flying at 60 to 70 miles an hour.

These were the first helicopters brought to Alaska by anyone, and they created a lot of excitement everywhere they went. For some reason, the dogs in the villages wanted to jump at the tail rotor, and the eagles on the Chichagof project were a constant threat. Many anxious moments were endured, but it was so much

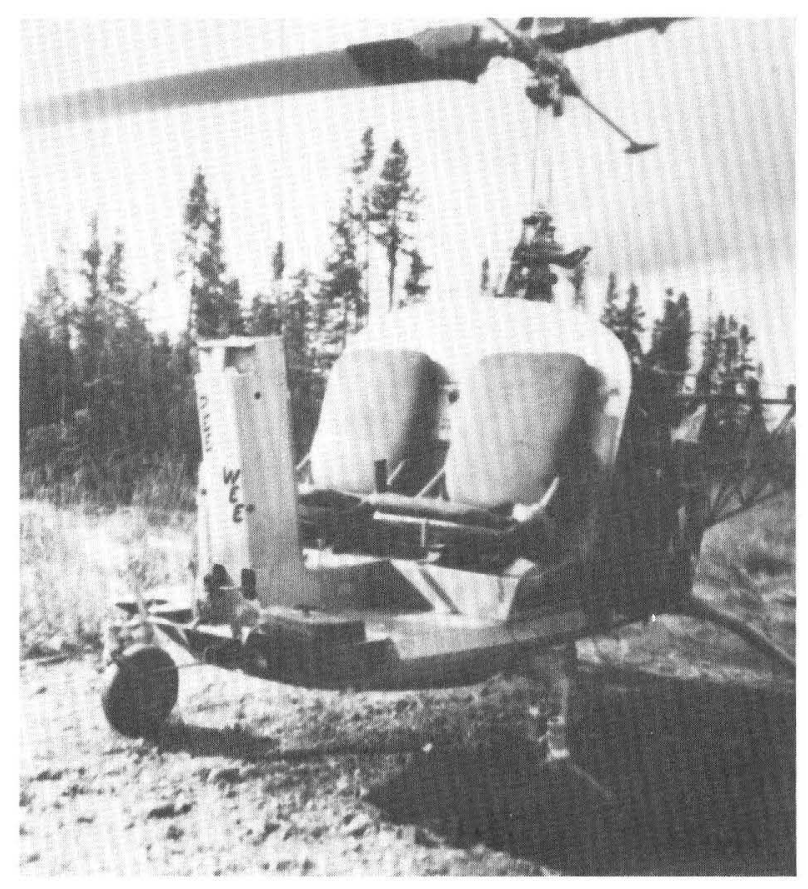

First helicopter used in Alaska, near Big Delta. This Bell helicopter was rated at 78 horsepower and carried Civil Aeronautics Administration license $11-\mathrm{H}$, the eleventh helicopter certified in the United States (1948). 
better than backpacking in the thick underbrush and timber that the fieldmen tended to disregard the risks. From the beginning, it seemed as if the machines were being used to their maximum ceiling and load. Most of the higher landings were "controlled crashes," and the takeoffs were equally thrilling.

After about a month of operation, the helicopter at Big Delta had a fuel pump failure and had to make an autorotation landing in a swamp. These early helicopters had four wheels for landing instead of skids or floats. One of the wheels sank into the swamp, and the helicopter turned over and burned. The pilot was alone, but was uninjured, and walked out to base camp 20 miles away. Because the accident happened near the end of the season, the helicopter was not replaced.

The crews in southeastern Alaska used boats for most of their transportation needs. The Survey's navy consisted of small 16- and 18-foot boats with outboard motors. The motors were 16 and 22 horsepower with auxiliary 5-horsepower motors for emergencies. Some of the boats were open, and some had small cabins. Many of the predicaments encountered with the small boats were probably much more dangerous than with the helicopters.

The old outboard motors did not have a reverse gear. When making a landing on rocky shores or on lone rocks offshore where large ground swells were present, it was necessary to shut the motor off and to control the boat with oars. One man would work the oars, and the field engineer would stand in the bow in preparation for landing. When the boat hit the

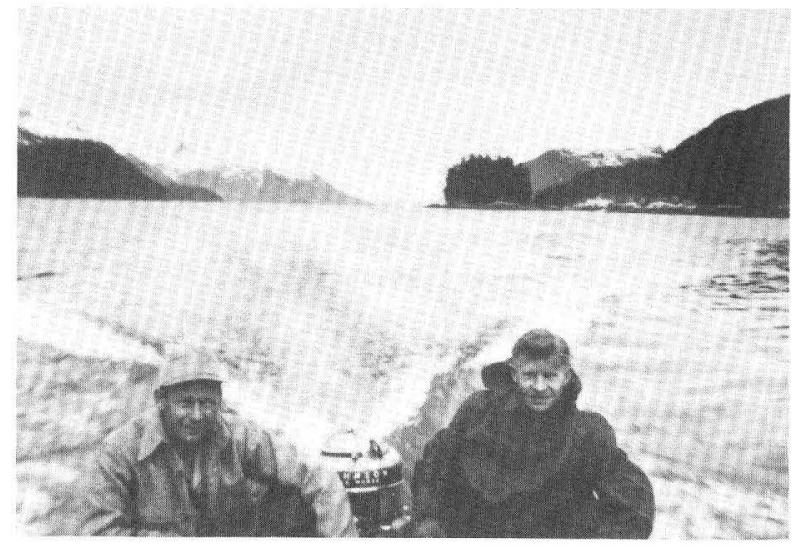

Author (right) in small boat at Pelican Camp (1948). rocks, the field engineer would jump off, carrying his instruments and photographs. The man in the boat would then row back offshore and wait until the fieldman signaled that he was ready to reboard. The oarsman would row back in, and, as the boat hit the rocks, the field engineer would jump back in. This was extremely dangerous when working in offshore waters because the swells were usually 10 to 15 feet high. If the fieldman had ever slipped on the wet rocks, then he probably would have drowned because the large swells would have tossed him against the rocks, knocking him unconscious. The man working the oars also had to be very careful not to let the boat get sideways in the swell because the boat would have been crushed or capsized against the rocks. He had to be able to pick out a good swell and to ride it into the shore, keeping the boat straight at all times.

Many landings were made under these conditions without any major mishaps. Occasionally, where a sandy beach was available to land on, the boat was shoved up on the beach by the swell and then filled with water over the stern. This was not dangerous; the men had to bail out the boat and shove it back off the beach. Occasionally, the men did not pay attention to the tide and would leave the boat unattended. When they came back after finishing their work, the boat would be high and dry. The boats were too heavy to carry back to the water, so the men would be stranded until the next tide came in.

The Big Delta project in the interior of Alaska was located in low and swampy terrain that was covered partially with a dense growth of 60 - to 70-foot birch and spruce. The crews working at Chickaloon and Sheep Mountain were establishing a triangulation arc in very rugged country to extend horizontal and vertical control. They built signals on peaks and on points that were identifiable on the aerial photographs. These points then were intersected from stations of known position and elevation to provide the required new photocontrol. Backpacking 30 to 35 miles (one way) through thick underbrush and timber often was required to reach the worksite. The equipment for backpacking included a Trapper Nelson packboard and very few of the convenient lightweight niceties of today's backpackers. 
Usually two men, carrying food, tent, sleeping bags, axe, saw, rifle, station marks, signal material, theodolite, and tripod, established and occupied the station. Swift glacial streams had to be forded by wading, by felling trees to form temporary bridges, or by using rubber rafts for the larger rivers.

Weather was a controlling factor in the progress of the work. Sometimes at the more remote stations, 2 to 3 days would be spent packing in; then a week of inclement weather would arrive, and no surveying could be completed. The food supply would become depleted, compelling a return to base camp and the rescheduling of the pack for a later date. Fortunately, the use of helicopters solved most of the inefficiency of establishing triangulation using backpack methods. A 30-mile-distant station, requiring 2 to 3 days of backpacking, could be reached in about 30 minutes by helicopter.

The party chief on the larger crews not only supervised mapping and surveying operations, but also acted as agency cashier for paying bills. Money for operating the party came directly to the party chief from the U.S. Treasury in $\$ 5,000$ amounts, issued in $\$ 50$ and $\$ 100$ checks. The party chief made direct payment for services rendered, such as boat and plane charter, equipment repair, groceries, temporary help, and so forth. This system necessitated that a large amount of cash be kept around camp; however, a safe place to keep it often was not available. Much time was expended by the party chief in obtaining properly documented receipts and in keeping detailed bookkeeping records.

The crew at Homer used a boat for shore work and packhorses for inland work. The crews at Yakataga, Tanacross, and Ferry went on foot. The 1948 season was probably more of a training period than a production period. The area controlled for mapping by all the crews was small compared to that of later years. Most of the projects were completed or terminated about the middle of September, and the crews returned to Denver.

\section{9}

Because of the experience gained in 1948 in the use of helicopters and of additional aerial photography coverage by the Air Force and
Navy, four major project areas were planned for the 1949 field season. In addition, one person was assigned a field completion project to check the military compilation on Kodiak Island. He had one field assistant and an 18-foot cabin boat. Three projects were worked from Ketchikan using small boats. A floatplane was chartered to establish water-level elevations with altimeters on the islands in some of the larger lakes.

This was the first season that altimeters were used to establish supplemental vertical control. The first altimeter surveys done in Alaska were with Wallace \& Tiernan altimeters using the high and low base methods. The altimeters were acquired from the military and were in wooden cases inside padded canvas carrying cases. The wooden cases were not airtight; so, to make a comparison test between instruments, the altimeters were carried up and down a mountain and read at every 100 -foot change in elevation.

A second project in southeastern Alaska was worked from Juneau. This project was controlled using one helicopter and two boats. The main base camp for this project was established at Bear Track Cove in Glacier Bay National Monument. One boat crew worked along the Lynn Canal from Point Howard to Skagway, and a second boat crew worked in Muir and Rendu Inlets, which are at the northern end of Glacier Bay National Monument. The helicopter operation was satisfactory except during adverse weather. The existing National Geodetic Survey control was photoidentified by the boat crews. Sea-level elevations were established on the existing control. The required vertical control for interior photopoints was established by altimetry. Sufficient horizontal control was established by triangulation, and reciprocal vertical angles were observed to establish good elevations for altimeter high bases.

Because of adverse weather, field operations were very slow in the Glacier Bay area. About the first part of August, the Geological Survey received a request from the Bureau of Reclamation to do four mile-to-the-inch quadrangles at Skagway for a powerplant study. The crew moved from Glacier Bay to Skagway and set up a camp in an old Army barracks. The weather was better at Skagway, and the work was com- 


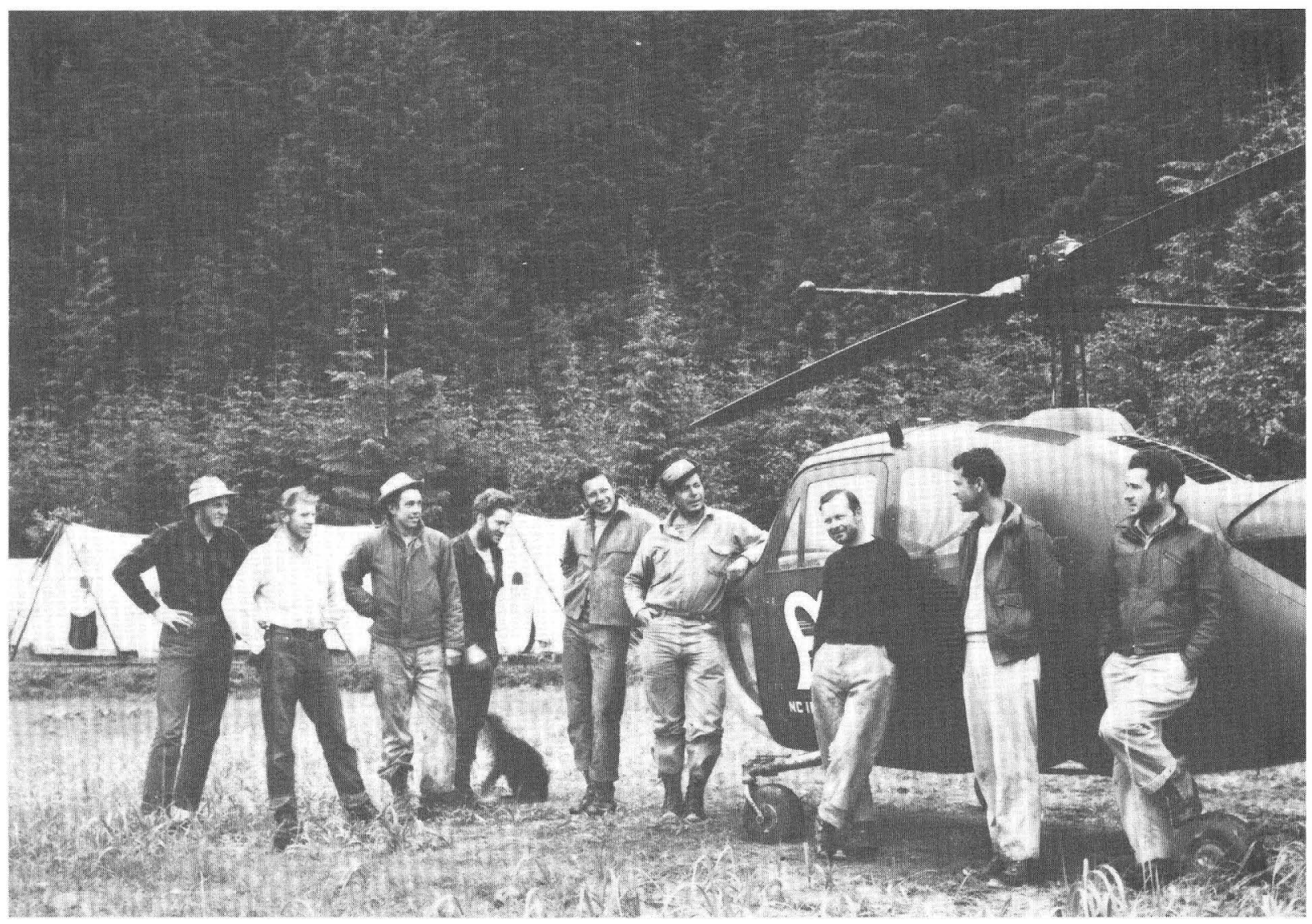

Crew at Glacier Bay (1949). (Photograph by Ansel Adams. Courtesy of the Trustees of the Ansel Adams Publishing Rights Trust. All rights reserved.)

pleted in 3 weeks. The weather improved in the Glacier Bay area, and that fieldwork also was completed. The boat crews from Lynn Canal and Glacier Bay were moved to Tenakee Springs to establish a triangulation arc at Tenakee Inlet.

The other two projects were in the interior of Alaska and were supplied from Fairbanks. Both project areas were along main highways. One area was near Gulkana, which is at the junction of the Richardson Highway and the SlanaTok Cutoff. The other area was at Tok Junction, which is located on the Alcan Highway. Both these projects were planned the same as the Glacier Bay project. The horizontal control was established by triangulation methods with reciprocal vertical angles, and the supplemental vertical control was established by high and low base altimetry methods. Both of the projects had helicopters. The Gulkana project had a successful season with their helicopter, but the Tok Junction project had two accidents that destroyed two helicopters; one helicopter had an engine failure and crashed near a sand bar in the Tok River, and the second accident was caused by pilot error on a mountain peak. Although both helicopters were completely demolished, no one was injured.

Even with the adverse weather in southeastern Alaska and helicopter accidents in the interior project, 1949 was a successful season. The crews were composed of 23 fieldmen, approximately 12 field assistants, and 6 helicopter crew personnel involved in the four areas. The square miles surveyed were considerably more than that accomplished in 1948. All work was completed about the middle of September.

With the use of helicopters and with personnel camping alone on mountain peaks, radio communication was essential. The Survey pur- 
chased several large radio transmitters and receiver units. The transmitters were 25 -watt Globetrotters, and the receivers were Hallicrafters with shortwave bands. Each camp had a unit, and other units were set up in Ketchikan, Juneau, and Fairbanks. Radio schedules were maintained each evening between camps and with town. The crews were able to order groceries and supplies each week.

Several small 5-watt radios were purchased for the field crews. These sets were not compatible with the large sets, but, under normal conditions, the men were able to talk to camp and between themselves. Many times when one man could not talk to camp, another could relay for him.

\section{0}

The four projects scheduled for the 1950 field season were in central Alaska. Two projects were along the Alaska Railroad, and two were along the Richardson Highway. Each project had one helicopter. The projects along the highway had trucks to haul fuel and supplies; the projects along the railroad had to depend on train service. The work on the four projects consisted of establishing primary control by triangulation methods to extend horizontal and vertical photocontrol. All classification and

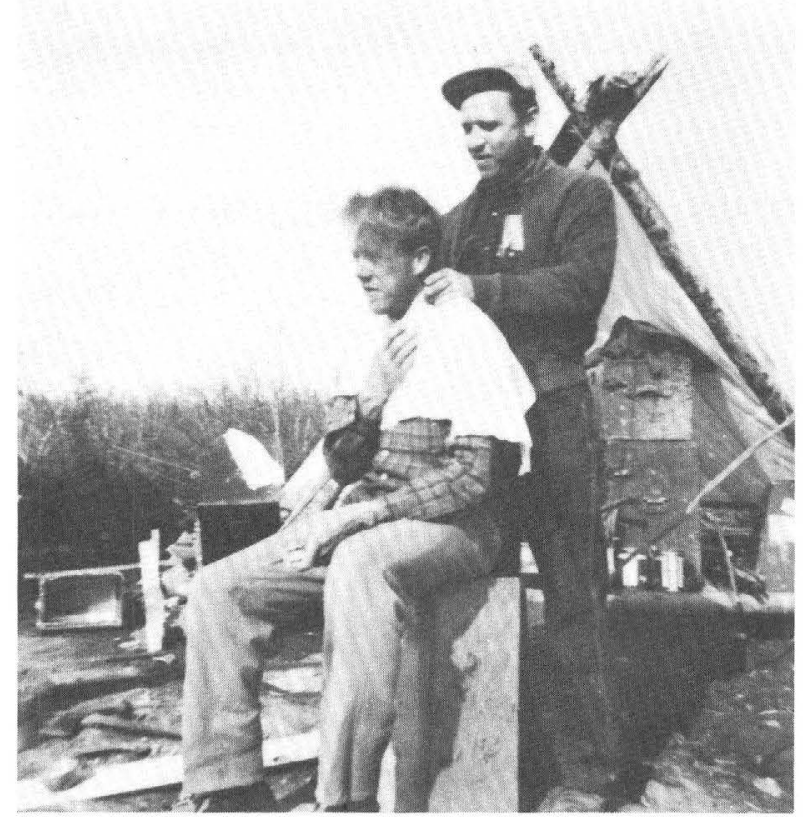

"Hair stylist" on the Gulkana-Tok project (1949). name information were done on the aerial photographs.

As more experience was gained in helicopter operations, new methods were adopted for more efficient use of flying time. In the early years of helicopter operations, it became evident that the most efficient method was to transport the triangulators out to the survey stations and to leave them. Each fieldman had his own two-man mountain tent, sleeping bag, and cooking utensils. Most high peaks are dry, so it was necessary to carry water. In the early years, the Survey had acquired C- and $\mathrm{K}$ rations from the military. These, as well as supplements of commercial canned meats and fruits, were used for food supplies on the peaks.

The helicopter could service three to four observers each day and occasionally accomplish some altimetry work in between moving observers. Usually, each observer would be out from base camp for about a week, then come in for a day to wash clothes, take a shower, and resupply and then go out again for another week. The observers on the peaks also would read the high base altimeters when needed. Sometimes an observer would be on a peak for 1 day and then move; other times, depending on the weather, the observer might get stranded for several days on the same peak. Normally, only the party chief, cook, field assistant, and helicopter crew would be in the base camp. All the observers had radios, so the party chief knew when each one was ready to move. He kept in contact with all field parties on regular radio schedules.

The field season of 1950 was a normal one. The weather is generally better in central Alaska than in many other areas of Alaska. Some time was lost because of the weather on the project on the southwestern side of the Talkeetna Mountains, where the crew started at Palmer and worked north to Talkeetna and Curry. Another crew, working along the highway, lost time due to smoke from forest fires. For a period of about 10 days, the smoke was so thick in the Tanana Valley that it was impossible to observe angles.

Three of the four helicopters performed well all season. Although the fourth helicopter, which was based at Palmer and Talkeetna, made several forced landings because of en- 
gine failure, no accidents were reported and no one was injured. Each crew made at least two moves, and two crews made three moves during the season.

One crew ended their season at Broad Pass, along the Alaska Railroad. When their fieldwork was completed, the crew packed all their survey instruments and camp equipment to ship on the train to Anchorage. They hauled everything to the depot except a few tents, sleeping bags, field notes, and aerial photographs. That night the depot caught on fire, and all the instruments, radios, and camp equipment were destroyed. The only reason the field notes and aerial photographs were not packed was one of the fieldmen still had some work to do on the photographs, otherwise the whole season's work would have been lost.

This was a very productive season. All the projects were completed about the middle of September, and everyone returned to Denver by the first part of October.

\section{1}

In spring 1951, the Rocky Mountain Region made preparations for the largest field season to date in Alaska. Thirty fieldmen were selected for seven projects. Six helicopters and two large boats were contracted for the season. One helicopter was assigned to each project, with one of the helicopters going to the seventh project late in the season. The two boats were to be used in southeastern Alaska to support helicopter operations as well as being mother boats for the crews identifying National Geodetic Survey shore control around Baranof and Prince of Wales Islands.

During the first week of April, an advance group of men left Denver for Alaska. One group left in a surplus heavy-duty military truck and three pickup trucks to drive up through Canada to Alaska. Two other men flew to Juneau to prepare camp equipment and boats for the summer work. The rest of the crews were to arrive during the last week of April, and helicopter and boat contracts were to start on May 1. The trucks were loaded with equipment and instruments. The heavy-duty truck also carried smoke grenades obtained from the U.S. Army at Fort Carson, Colorado. The grenades were to be used when landing

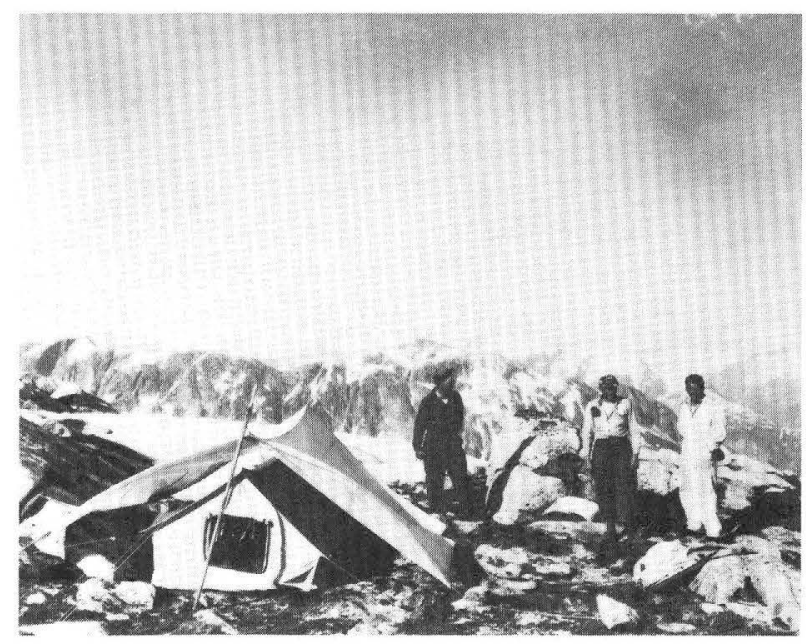

Triangulation station near Taku Harbor (1951).

the old underpowered helicopters to indicate wind direction. Also, approximately 100 cases of C-rations were loaded on the trucks. The Crations were to be used by the fieldmen camped on the triangulation stations and altimeter bases.

During the trip through Canada, the larger truck was found to be too heavy to drive on some of the highways where load limits were in effect during spring thaw, and the truck had to be shipped by rail from Edmonton to Dawson Creek. While in shipment, someone broke into the load and stole several typewriters and one man's dufflebag with all his work clothes. The Canadian Mounted Police at Dawson Creek said that the missing items probably never would be found. Later, while driving along the Alcan Highway, some of the smoke grenades caught on fire. As the men were throwing the burning cases off the truck, a Canadian motorist stopped to help. When he saw "Grenades" stamped on the cases, he ran back to his car, jumped in, and sped off. After about 10 days on the road, the trucks arrived in Alaska. This advance group had to work hard to get the camps set up at Lake Louise, Clarence Lake, Chitina, and Cordova for the arrival of the crews before May 1.

Meanwhile, the two men who had flown to Juneau earlier were busy painting boats and getting outboard motors running. Contracts were awarded for two large boats, but, about 4 days before work was to begin, the U.S. 
Coast Guard inspected the boats and said neither one could be used in outside waters, although they could be used in inside waters. That caused a dilemma. After talking with other agencies in Juneau that used large boats, the men discovered the Bureau of Mines did not have any work scheduled for their boat during the summer. The boat and skipper were leased for the season for use in outside waters, and one of the contract boats was kept for use in inside waters. The contract was canceled for the other boat. After all the confusion, the boats were loaded, and the crews were moved to camps at Tenakee Springs and Baranof Hot Springs. The camps and crews were ready to start work on May 1 as soon as the helicopters arrived. When all the camps were set up and the crews moved in, approximately 60 men, including the field engineers, assistants, cooks, and helicopter crews, would be spending the season in Alaska.

The season progressed very well with only minor mishaps. The four crews in the interior had good weather, and their helicopters performed well. They were able to complete the work that was scheduled by the first part of September. The crews in southeastern Alaska had exceptionally good weather for that area. One of their two helicopters had some engine trouble and made two forced autorotation landings in water; one landing was at Baranof Hot Springs at base camp, and the other was made in an inlet called Deep Bay, which was approximately 30 miles south of the base camp. The helicopter from Tenakee Springs was sent to bring the pilot and fieldman back to the Baranof Hot Springs camp. The Bureau of Mines boat was large enough and had a boom that could lift the helicopter on board, so it was sent to get the helicopter and take it back to Juneau where the engine was changed. Because of adverse weather, the rescue mission took 10 days instead of the planned 4 days. The pilot flying the helicopter at Tenakee Springs had a nervous breakdown about the middle of the season and had to be replaced.

The fieldmen using the boats had a slow time during May. The first trip was planned to work the outside waters on the western side of Baranof Island. Work started about May 5 at Cape Ommaney and ended Memorial Day at Sitka, a distance of only 70 miles. High winds

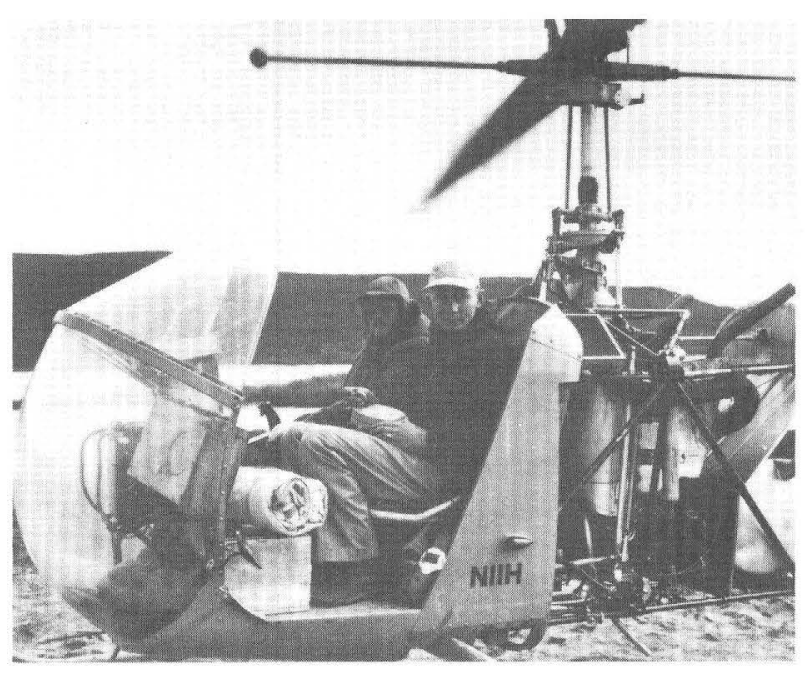

Fieldman going to work at Clarence Lake (1951).

and heavy seas made it very difficult to land on shore or on offshore rocks with the smaller boat. Later in the summer, the larger boat was detailed to work the outside waters on Prince of Wales Island from Cape Muzon to Craig. This trip was almost as bad as the trip up the western side of Baranof Island. The rest of the boat work was on inside waters, and not many days were lost because of weather.

The boat crews photoidentified existing $\mathrm{Na}$ tional Geodetic Survey control and classified all the culture along the coasts, such as villages, canneries, and isolated cabins. They also gathered name information from local inhabitants. Both boat crews completed work by the first part of September, and the equipment and crews were brought back to Juneau. This was a very successful season, especially considering the number of men, helicopters, and boats working in all kinds of weather and terrain. Fortunately, no injuries occurred.

\section{2}

During fall 1951, the Rocky Mountain Region decided to establish a permanent office in Fairbanks to complement the Geologic Division's Resident Geologist, who maintained an office at the University of Alaska. One man was assigned to this office and was known as the Alaska Resident Engineer. In the summer, when the field crews were in Alaska, the Resident Engineer coordinated all field mapping 
activities. In the winter, he gathered information for updating reprints of existing maps, answered questions from the local populace concerning horizontal and vertical control, and served as a liaison with other Geological Survey divisions. Along with office duties, the Resident Engineer made preparations for the summer camps, including arrangements for delivering helicopter fuel to camp areas. Many of the projects were located in areas where everything had to be transported in by air. Logistics are about 75 percent of surveying in Alaska, and, when you have to depend on charter aircraft and unpredictable weather, the logistics work takes a lot of patience and understanding.

The field season of 1952 was a small effort compared to the previous season. Two projects were planned, and only eight men were assigned to work the projects. One project was to start at Sourdough Creek, northeast of Fairbanks, and then move to Dot Lake east of Big Delta along the Alcan Highway. The other project was to start at Central, near Circle Hot Springs, and to finish at Woodchopper. Two helicopters were contracted for the season. This was a normal season with only the usual difficulties. The work progressed very well, and both projects were completed on schedule.

The project at Central had a near catastrophe with a grizzly bear. When the fieldman and helicopter arrived at a triangulation station to make observations, a grizzly bear was awaiting them at the station. The pilot chased the bear down the ridge with the helicopter and then dropped off the fieldman at the station. As the fieldman was making preparations to set up his camp, the bear returned, growling and acting very fierce. Luckily, the fieldman had a rifle with him, and he killed the bear. He then continued to set up camp and get ready to observe the station. When he removed the rock cairn that was holding up the signal, he found a bear cub. It was unfortunate that he had to kill the mother, but he was unaware of the cub. This was the only incident with bears where one of the fieldmen was in danger. Many incidents of black bears getting into camps and garbage pits occurred, but no lives were in danger.

The only vehicle accident that occurred in Alaska happened near Dot Lake. Two of the fieldmen and the camp cook left camp on Saturday evening and drove to a roadhouse about
20 miles up the highway. On the way back to camp, the driver fell asleep, and the truck veered off the road and overturned. Sometime later, an Army convoy came along and found the wrecked truck and the three unconscious men. The Army personnel decided that two of the men were alive and one was dead. They put the two injured men inside an Army truck and laid the dead person on top of a trailer and lashed the body down with rope. The convoy proceeded about 50 miles to Big Delta Air Force Base, where they immediately took the two injured men to the base hospital.

When they were taking the "dead" person off the trailer, they discovered he was not dead after all! They immediately rushed him to the hospital also. One of the fieldmen did not respond to treatment very well, so they rushed him to Fairbanks' Ladd Field Hospital.

The party chief in camp at Dot Lake did not know anything had happened for 3 days. The military people finally called the Geological Survey office in Fairbanks and inquired if the injured men worked for the Survey. By this time, it was determined that none of them were seriously hurt, other than concussions. The Resident Engineer in Fairbanks went to the two hospitals and got the men released and returned them to camp.

The cook lost his false teeth in the accident. When some of the fellows in camp returned to the scene of the accident to look for his teeth, they found his upper plate in the frontyard of a homesteader's place about one-fourth of a mile away, where a dog had carried them.

\section{3}

One large area was to be worked during the 1953 field season. Two crews were selected to establish horizontal and vertical control for 1:63,360-scale mapping of the Tanana and Kantishna 1:250,000-scale quadrangles. One crew set up camp at Manly Hot Springs, and the other crew set up camp at the Lake Minchumina Civil Aeronautics Administration station. Each camp had one helicopter and chartered fixed-wing aircraft when needed. The season started badly at Manly Hot Springs because the helicopter had mechanical trouble before it arrived at camp. In fact, the whole season was plagued by mechanical fail- 
ures of the helicopters and by pilots getting lost. By the first part of July it was decided to eliminate one camp and to combine the crews and helicopters. Several men returned to Denver early, and the rest flew from Manly Hot Springs to work out of Tanana for 3 weeks and then to Lake Minchumina. A lot of time was spent cutting down trees because many of the stations were in timbered areas or on mountaintops covered with trees. Several black bears were shot because of real or imagined threats. One bear tried to get into a tent, tearing it open, while the occupant was inside. In spite of all the helicopter trouble, considerable work was accomplished. Several phototheodolite stations were completed along the northern side of Mount McKinley, and a control tie was made into the Mount McKinley triangulation arc.

One man was detailed to the National Geodetic Survey camp at Fort Yukon to work with the crew who were establishing horizontal control along the Yukon and Porcupine Rivers. The Yukon Valley is 50 to 60 miles wide, flat, and densely timbered. The timber is birch and reaches heights of 90 to 100 feet adjacent to the river. The National Geodetic Survey was establishing a triangulation arc along both sides of the river, which required towers that were 80 to 110 feet high. While the National Geodetic Survey was observing from their towers, the Geological Survey asked if they could establish a few horizontal stations on some of the pingos (small domed-shaped hills) scattered around the valleys. The Geological

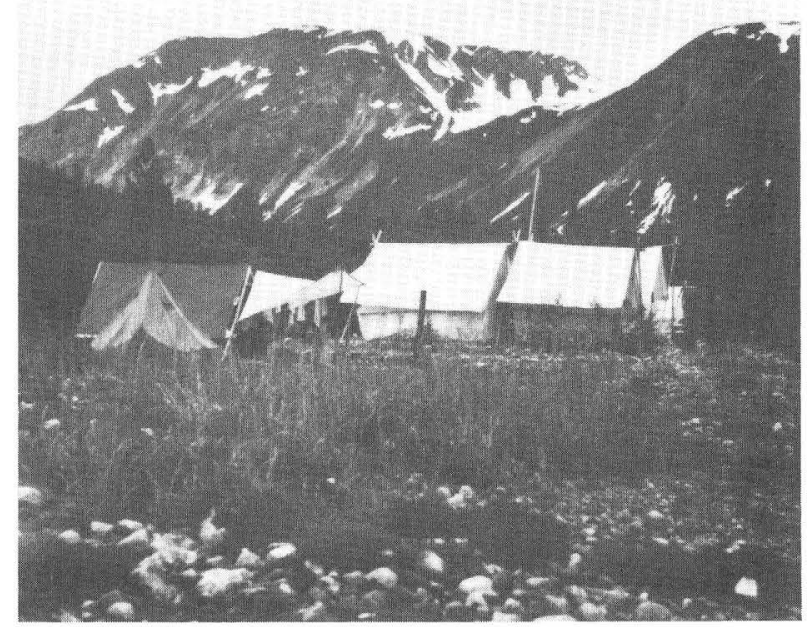

Typical Survey camp in Alaska (circa 1950's).

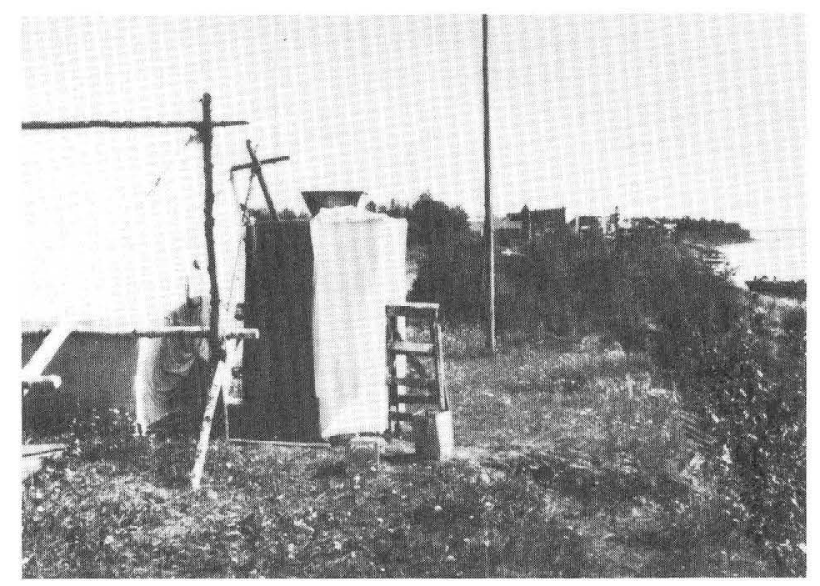

All the comforts of home-shower at Tanana (1953).

Survey would then have control from which to extend photocontrol at a later date without having to go back and build towers. It was impossible to see anything from the ground at the existing stations established by the National Geodetic Survey along the rivers.

The project area was not completed during the field season even though the crew worked until the middle of September. Miraculously, no one was injured, although there were many forced helicopter landings and mechanical failures.

\section{4}

Three areas were planned for the field season of 1954. Two crews and two helicopters were scheduled. The first area to be worked was at Wells, north of Haines. The crews and the helicopters were combined for this area. The helicopters were new Hiller Model D helicopters. One pilot and a mechanic were on loan from the Hiller Company; the second pilot had been flight checked before coming to Alaska and was competent in the Hiller. This was the last year the field crews would come up on the Alaska Steamship Line. Passenger service was discontinued within a year after that summer. Work started about May 15 and was completed about June 10.

The area of operation had vast snowfields and glaciers. The helicopters were equipped with duck feet or pads on the rear of the skids. During the first week, one helicopter with pilot 
and fieldman made a landing on a peak where some rock was exposed. The pilot had the front of the skids on the rock and the rear in the snow. When he turned off the power to the rotor and the ship's weight shifted to the skids, the rear of the skids broke through the snow crust and the helicopter turned over backward. Because the rotors were still turning, the helicopter was destroyed completely. The pilot and fieldman received only minor scratches. The other helicopter rescued the men, and, when time was available, the helicopter crew dismantled the wreckage and ferried it back to the Survey camp. When they had retrieved all the parts, the helicopter was shipped back to Seattle. The wrecked helicopter was replaced by an old open-cockpit Bell, which was used for the rest of the season.

About June 10, when this part of the fieldwork was completed, the crews moved to the interior of Alaska by way of Fairbanks. Moving arrangements had been made for fuel caches for the helicopters so they could avoid Canadian customs. Canadian regulations require aircraft to clear customs if they land anywhere in Canada.

The day the helicopters left Wells en route through Canada to the interior of Alaska, the pilots decided they wanted a cup of coffee at Haines Junction. They made the mistake of landing in the Canadian Mounties' compound. Immediately upon landing, the Mounties grounded the helicopters because they did not have clearance through Canadian customs to stop in Canada. After several telephone calls to Ottawa, the helicopters finally were released and were given permission to leave the following morning. After 3 days, the helicopters and crews arrived in Fairbanks. From Fairbanks, arrangements were made to ship the camp equipment to Mount McKinley National Park and Talkeetna by train.

One crew was to set up camp at Wonder Lake in Mount McKinley National Park, which is about 90 miles by road from the Park headquarters on the railroad. The crew shipped a heavy-duty truck and two pickup trucks by train to Park headquarters and then used the trucks to haul camp equipment and personnel to Wonder Lake. The other crew unloaded all their camp equipment at Talkeetna and chartered a small plane to haul their equipment to
Skwentna, which was a Civil Aeronautics Administration station located 60 miles southwest of Talkeetna. After about 10 days of moving and setting up camps, work began on the project areas.

The crew at Wonder Lake was concerned primarily with finishing the work started in 1953, which consisted of using phototheodolite equipment to control the northern side of the Alaska Range. Fuel caches established the previous season were used. The phototheodolite is an instrument constructed with a terrestrial camera and a T-2 theodolite mounted on top of the camera. Because the camera exposure covers 40 degrees, it takes nine exposures to complete 360 degrees of arc. Generally, only a few exposures are made from a given point. The camera is oriented by using the theodolite to fix on an existing horizontal station that is visible in the photograph. With the camera oriented on a true azimuth, a horizontal or vertical angle can be measured to any point visible on the photographs. By using the phototheodolite from a number of existing horizontal stations, it is possible to establish intersected stations and elevations on points that are common on photographs taken from several locations.

The phototheodolite used glass plates with a soft emulsion on one side. The high-resolution fine-grain film was very slow, generally taking 4 to 10 seconds per exposure. The camera does not have a shutter, so, to take an exposure, you merely take off the lens cap and count the seconds, based on a predetermined exposure time from test photographs of each new set of plates.

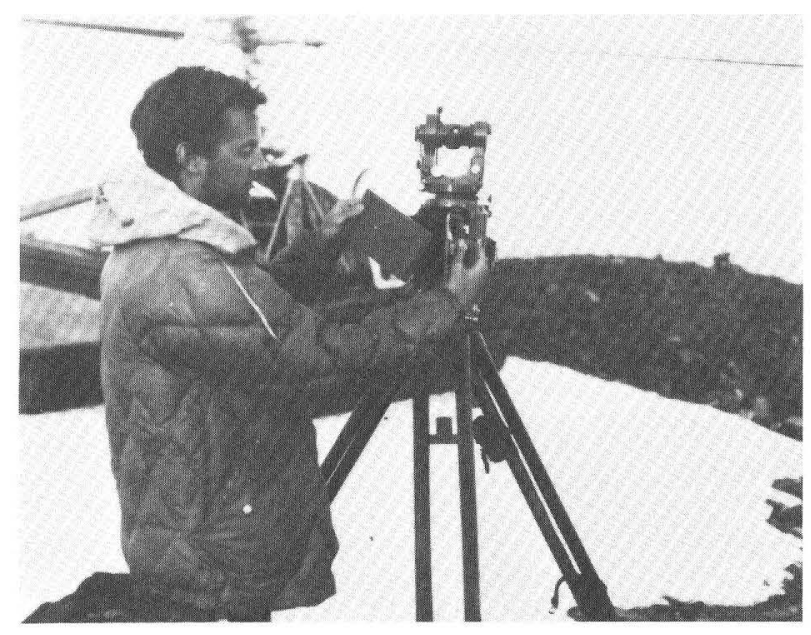

Inserting glass plate in phototheodolite (1954). 
The measurements on the photographs were made in the office on an instrument called a goniometer.

The crew at Skwentna was to establish horizontal control to be used for phototheodolite stations to control the southern side of the Alaska Range. The helicopters at this time were limited to approximately 5,000 feet in elevation. On days when wind and temperatures were favorable, higher landings could be made. Because of the high terrain in this area of the Alaska Range, the phototheodolite was used to control most of the Range from Mount McKinley National Park south to Lake Chakachamma, west of Anchorage.

The crew at Wonder Lake had a difficult time trying to take pictures of the area around Mount McKinley because it was covered with clouds about 97 percent of the summer. Three of the men spent 6 weeks with the helicopter in a remote campsite at Amos Lake, which was about 50 miles west of Wonder Lake, trying to take pictures on the northwestern side of Mount McKinley and Mount Foraker. They never were able to finish their observations. The crew at Skwentna had poor weather also but did complete the triangulation arc from Curry, on the railroad, to Cook Inlet, near the mouth of the McArthur River. The arc was 110 miles long, and enough stations were established to do the phototheodolite work on the southern side of the Alaska Range. The crew at Skwentna also were able to do the altimeter work and photocontrol for lowland areas in the Susitna Basin around Skwentna and Talkeetna.

During the last week of August, the crew at Wonder Lake moved their camp back to the railroad. They had a temporary camp at the Civil Aeronautics Administration station at Summit for several days, doing phototheodolite work on the eastern side of Mount McKinley. After finishing the work at Summit, they moved to Curry where they were to stay at a riverside hotel operated by the Alaska Railroad. The crew rode the train from Summit to Curry with all the equipment. The helicopter pilot, accompanied by one Survey man, flew the helicopter to Curry. Approaching Curry in the helicopter, the pilot followed the river toward the hotel. As they flew around the back of the hotel, they ran into a cable that was stretched across the river from the hotel chimney to a tree. The cable caught on a crossbar on the bubble of the helicopter. The pilot, reacting quickly, applied more power, hoping to break the cable. The cable did not break, but it did pull the chimney off the hotel. This occurred about noontime, and the people in the dining room ran out to see what was happening. Luckily, when the chimney came down, it pulled the cable away from the helicopter and did not catch on the skid. If the cable had caught, then it could have turned the helicopter upside down in the river. Had this happened, the deep, swift river would have claimed several lives. After the helicopter landed, it was determined that the only damage was a groove in the bubble where the cable had sawed back and forth. The hotel suffered considerable damage because the brick chimney had disintegrated and made several holes in the roof. The helicopter company's insurance took care of the repairs. The hotel burned down in 1959.

Very little work was accomplished at Curry because of adverse weather. Both crews terminated work on September 10 and moved their camps to Anchorage and stored the camp equipment.

After working in the Susitna River Basin all summer, it became evident that phototheodolite work on the southern side of Mount McKinley and the Alaska Range in the summer was nearly impossible. After talking with local people who lived there the year around, it appeared that the latter part of April and all of May was the most favorable time for work on the southern side of Mount McKinley. At that time, the temperature of Cook Inlet and the Alaska Range are nearly the same, and the clouds do not build around the mountaintops. The warmer Cook Inlet becomes in the summer, the more the fog and clouds build up around the high peaks as the warm air meets the cold air off the glaciers.

This season was not as successful as others because of the weather and working conditions around the highest terrain in North America. The crews returned to Denver about the middle of September.

\section{5}

The field season in 1955 was a cleanup operation. Projects in several areas had not been 
completed, and several quadrangles needed control to fill in unmapped areas.

Two crews consisting of eight men from the Denver office were scheduled for Alaska. The crews left Denver in early May for Ketchikan to prepare for two small projects, one north of Ketchikan at Bell Island and one east of Ketchikan. Two helicopters were contracted for the season, and a 52-foot boat was leased from the Forest Service at Petersburg. The boat was used to move the camp to Bell Island and then as a mother boat for the Ketchikan crew to photoidentify existing National Geodetic Survey control. The two helicopters were sent to Bell Island to start the season. During the first week in the Bradfield Canal, one helicopter was damaged due to pilot error. It was on floats and catapulted upside down during a bad takeoff. It remained floating for 11 hours before being located by the Coast Guard. The pilot and Survey man were not injured and were able to get out of the ship. They were sitting on top of the floats when the Coast Guard arrived. Both men were badly sunburned.

The loss of the helicopter slowed down the work at Bell Island. The crew at Ketchikan had to bring in another helicopter to complete the work. Both projects were completed about July 4, and the crews were moved to the interior. One crew was scheduled to go to Dot Lake, and the second crew, to Gardiner Creek.

The helicopter that was damaged in the Bradfield Canal accident was completely rebuilt and returned to work in time to move to the interior projects. The move was completed in about a week after clearing up a minor problem with Canadian customs at Whitehorse. The helicopters were grounded because the pilots did not report to the customs officer at his home in late evening. After the pilots each paid a $\$ 40$ fine, the helicopters were released the following day.

The project at Gardiner Creek was only five quadrangles. The work consisted of establishing primary control by triangulation to extend horizontal and vertical photocontrol, classifying culture, and gathering name information. During the second week of work, the helicopter was wrecked making an altimeter run. The accident was attributed to pilot error. The pilot was making a helicopter landing on a rounded

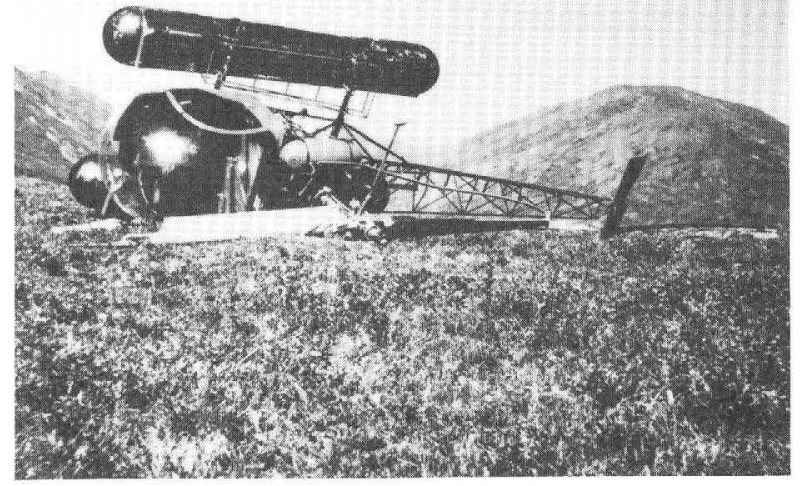

Bell Model 476 helicopter after a bad landing near Northway (1955).

knoll and did not have sufficient engine power. He landed too hard, and the helicopter turned over. No one was injured, but the pilot and fieldman were lost for 26 hours. The other helicopter was brought in from Dot Lake and searched for about 8 hours but was unable to find them. A Search and Rescue Unit was called from Fairbanks. They arrived about 4 hours later at Northway and were briefed on the area where the helicopter should be. They found the helicopter about 3 hours later. The other helicopter was sent to bring the men back.

The wrecked helicopter was replaced by a leased ship from Anchorage. The leased ship was an old military Hiller that had been salvaged. The fieldwork was completed at

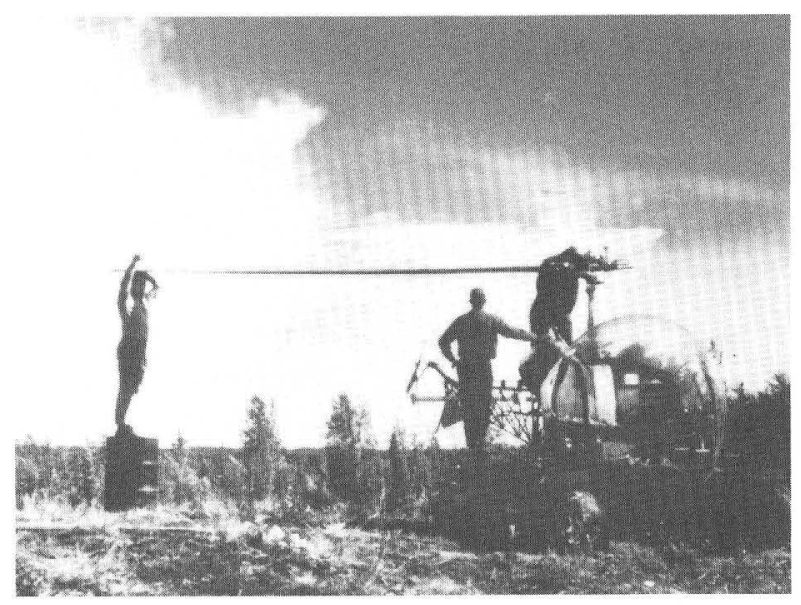

Changing damaged helicopter blades onsite, Gardiner Creek (1955). 
Gardiner Creek about the first part of August, and the crew moved to the village of Central to finish the work started in 1952. The crew at Dot Lake had enough work to keep them busy until the last of August.

The work at Central progressed well. Because the crew at Dot Lake had finished their helicopter work, both helicopters were available at Central. On the next to last day of helicopter work at Central, another helicopter accident caused by pilot error occurred. The wind had started to blow very hard and became very gusty. The helicopter was making an altimeter run and was approaching a peak. The approach angle was low, and it was caught in a downdraft on the lee side of the peak. The pilot did not have sufficient power to pull the helicopter out of the downdraft, and it hit the side of the peak just below the summit. The pilot, in trying to overcome the downdraft, had applied full power so that on impact, the helicopter literally bounded in the air at full power and did an airborne loop and landed upside down several hundred feet down the mountain. Because this landing would have been the last one before refueling from the cache down in the valley, no fire ignited in the almost-empty fuel tanks. Fortunately, the portable radio was undamaged, and the pilot and fieldman were able to contact base camp and to relay their circumstances and location. Shortly after the accident, darkness and a storm arrived. The next day, during a break in the weather, they were picked up in the valley below the peak where the crash had occurred. The altimeters and salvagable parts of the helicopter were picked up several weeks later. Work was completed in the next few days.

The day the crew broke camp at the Alaska Road Commission central compound, it was raining and overcast. After they loaded everything into trucks, the crew started down the Steese Highway for Fairbanks. The helicopter, which had mechanical problems, proceeded them, flying along the road. As the crew approached Eagle Summit, they overtook the helicopter, which was parked on the highway because the pass was "closed in" with low clouds. The crew had borrowed an Alaska Road Commission dump truck, which was painted yellow, to make the move. By proceeding slowly down the road with the helicopter hovering along be- hind the dump truck, they were able to lead the helicopter over Eagle Summit and down the highway until they were out of the clouds. The helicopter made it back to Fairbanks without mishap. The camp equipment was stored, and the crew left for Denver about September 10.

\section{6}

In 1955, the northern part of Alaska, known as the Brooks Range Project, was authorized for mapping. This mapping was funded by the Air Force. The Air Force was constructing the Dew Line and White Alice installations, which were radar and communication sites, and needed topographic maps to determine where blind areas on their radar screens might be. Preparations were made to fly transverse-oblique aerial photography, and a contract was awarded. The Geological Survey sent one man from the aerial photocontracting office in Washington, D.C., to inspect the photography as it was flown. The contractor had three P-38 military planes equipped with cameras. The planes were located at different sites to enable them to take advantage of clear weather. Although they were on site all summer, they did not complete the flying and had to return the following summer to finish.

The project was authorized for 1:250,000scale mapping. The area to be mapped was about the size of the State of New Mexico, or 120,000 square miles. This was the largest project to be undertaken in one season in Alaska by the Survey. Because of the remoteness of the project, logistics were by far the biggest challenge.

The Resident Engineer in Fairbanks started making plans and arranging for charter aircraft in early spring to haul helicopter and plane fuel out to the different areas. He planned to use airstrips at Bettles, Fort Yukon, and Umiat, plus large lakes that were strategically located. The military at Ladd Field in Fairbanks hauled loads of fuel to Bettles, Umiat, and Fort Yukon in C-124 aircraft. C-46 planes, which could land on ice, were chartered to haul the fuel to the lakes. Conditions had to be right for the planes to land on the frozen lakes, so a small plane equipped with skis was sent out early to mark a runway on the ice, and several other flights with small planes were made to test the 
snow conditions. Large caches of fuel in drums and cases were established at Liberator Lake in the western Brooks Range, and an extra planeload was placed at Schrader Lake in the eastern Brooks Range after an attempt at another location was aborted because of adverse weather. This extra 6,000 gallons was in about 60 drums and 200 cases.

The first flight by Survey personnel was made in a Widgeon to Fort Yukon, where they left supplies for the Old John Lake camp that was being established. They then flew on to Schrader Lake, where the Widgeon broke through the ice on landing. Using materials from wooden fuel cases and pieces of plywood and lumber from an abandoned camp at the southern end of the lake, they were able to get the plane back on solid ice. The fuel supplies at Liberator Lake were moved off the ice by the pilots and Survey crew. The cases of fuel were cached at various locations in the Brooks Range along the proposed traverse lines. Everything eventually worked out, and all the fuel for the summer season was out before the spring thaw.

Planning for the field operations started in January in Denver. The three men who were to be party chiefs were brought in the office and did all the planning for the horizontal and vertical control needed for the 1:250,000-scale quadrangles. The area was divided into three projects, and each party chief planned his own area. This proved very helpful because each man could become familiar with the terrain and problem areas that he would encounter before

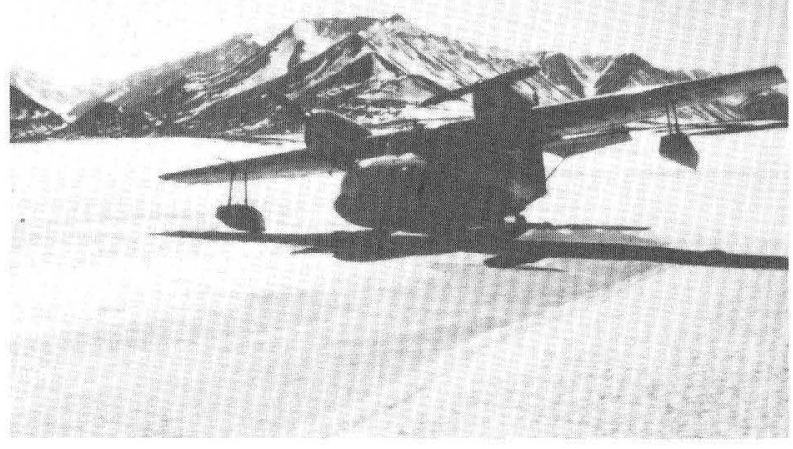

Widgeon after breaking through the ice at Schrader Lake (1956).

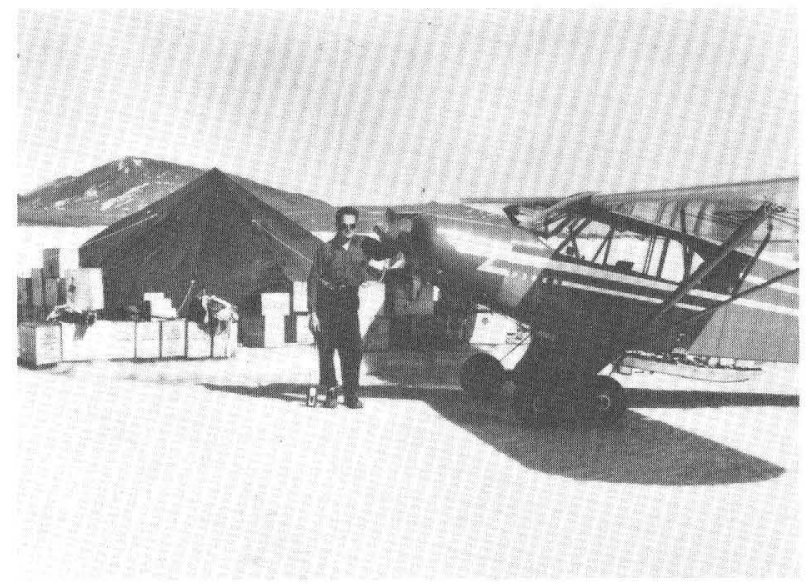

Preparing to haul fuel off Schrader Lake to designated areas for helicopter caches (1956).

going to the field. The aerial photography was flown east and west at 36,000 feet. The original plan was to scale the area with the twinplex instrument. The plan called for establishing vertical control lines in a north-south direction at 40-mile intervals. These traverse lines were established by phototrig traverse and leap-frog altimetry.

Each phototrig traverse line started from and closed on existing triangulation on which vertical angle elevations had been established. The distance between points along the traverse was not to exceed 2 miles, and the vertical angles were not to exceed 3 degrees. Each point was marked with an aluminum pipe and paneled. Panel photography was flown at approximately 5,000 feet and used surplus Air Force K-20 cameras. Vertical angles were observed simultaneously, and altimeter readings were taken.

The drawback to phototrig traverse is that computations had to be made in the office after the horizontal scale solution was completed and the traverse points plotted on the base sheet. The distances were scaled from the base sheet and computations completed. One misidentified point would invalidate an entire line. Some of the lines closed well, and others, not so well. This method was adequate for 1:250,000-scale mapping at 100 - and 200 -foot contour intervals. If this project could have been worked 2 or 3 years later when electronic distancemeasuring equipment was available, then the results probably would have been better.

Twelve phototrig lines were planned north and south from the Canadian border on the 
east to the Misheguk Mountains on the west that joined the military mapping projects. These traverse lines varied from 72 to 204 miles, with a total of 1,700 miles for the 12 traverses. Very little additional horizontal control was required because the area was surrounded completely by control established by the National Geodetic Survey, the International Boundary Commission, and the military. The National Geodetic Survey also had a triangulation arc that ran north and south from the Yukon River north of Fairbanks, through Bettles, and across the Brooks Range through Anaktuvuk Pass to the Arctic Ocean. This triangulation arc fell near the center of the project area. The National Geodetic Survey had started another arc northeast of Fort Yukon, on the Porcupine River, that extended to just south of Arctic Village. The crew on the eastern side of the project extended this arc up to the divide of the Brooks Range. The distances between horizontal control arcs averaged about 120 miles.

During the spring, contracts were initiated for helicopter and airplane support. Each camp would have two helicopters and one airplane. The airplane contract called for two Super Cubs, two Cessna 180's, and one Widgeon. The Super Cubs were equipped with tandem wheels, which were considered adequate for landings on gravel bars and unimproved airstrips. The Cessna 180's were on floats, and the Widgeon was an amphibian plane. The planes were moved around from one camp to the other, depending on needs. The Widgeon was used for hauling groceries and moving camps. The Cubs were used basically for caching fuel for helicopter operations.

Thirteen men left Denver on May 15 and flew to Fairbanks. A week was spent in Fairbanks preparing the camp equipment and purchasing groceries and other miscellaneous camp needs. The Resident Engineer had made previous arrangements for campsites. The first campsites were located at Old John Lake, Bettles, and Hughes. C-46 cargo planes were arranged for transporting the camp equipment to the three sites. The helicopters arrived in Fairbanks from Yakima, Washington, on May 20 by way of commercial air carrier. They were assembled and ready to fly on May 25. The Widgeon had reported earlier and had made sev- eral flights to various campsites to prepare for the arrival of the equipment.

The camps at Bettles and Hughes were set up along the airstrips in the villages. The camp at Old John Lake was located on the lakeshore, so the $\mathrm{C}-46$ cargo planes landed on the lake ice. Five tons of camp equipment and 200 cases of aviation fuel were unloaded about one-half mile from shore. An Indian from Arctic Village with a dog team and sled was hired to haul the equipment and fuel to the campsite on shore. All three camps were set up and in operation by early June. Other than minor breakdowns and bad weather, the operations proceeded very well.

The phototrig traverse method of establishing vertical control had not been used before, so each crew had to establish their own routine. Simultaneous reciprocal vertical angles were observed at each station. Each station was paneled, and photographs were taken from the airplane with a $\mathrm{K}-20$ camera to aid in photoidentification. Originally, it was planned to take the photographs at 1,200 and 5,000 feet. After the first photographs were taken, it was decided that the low-altitude photographs were not practical, and only the higher altitude photographs were obtained. Also, it was necessary to panel and photograph selected existing horizontal control stations.

All three crews had exceptionally good weather and very few mechanical failures with aircraft. Consequently, work progressed much faster than was anticipated. The crews at Bettles and Hughes had to move three or four

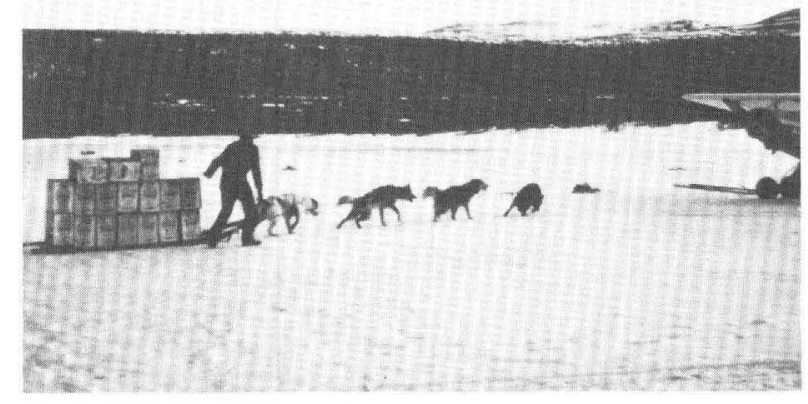

Dog team hauling fuel off the ice at Old John Lake. Each load weighed approximately 1,500 pounds. 
times to ensure efficient helicopter use. The crew at Old John Lake was able to work the eastern one-third of the area from the one camp. One man, working out of each camp for short periods, spent the season gathering name and cultural information. Most of the time he used one of the Super Cubs to travel between villages. A $\mathrm{K}-20$ camera was used to take pictures of isolated cabins and villages, and the pictures were later correlated with the aerial photographs.

The fieldwork was completed on the three areas about the last week of July. The Resident Engineer in Fairbanks already had alerted the Denver office that more material was needed to keep the crews busy until the helicopter contracts ran out in September.

The crew at Old John Lake moved their camp to a sandy beach on the Black River, about 60 miles east of Fort Yukon. Field material had been sent from Denver to establish horizontal and vertical control on the Black River quadrangle, portions of the Fort Yukon quadrangle, and the Charley River quadrangle. These 1:250,000-scale quadrangles were photocontrolled for 1:63,360-scale mapping. Work progressed rapidly, but, during the second week of August, it started to rain. The rain was not heavy at the campsite; apparently in Canada near the headwaters of the Black River, however, the rain was very heavy. After about 3 days of watching the river rise, it became apparent that the camp was going to be flooded, and no high ground was nearby on which to place the tents. The helicopters were sent to Fort Yukon for several days while the Survey crew moved the camp to Circle with the float-equipped Cessna 180. The plane made 13 trips out of the flooded area. Several tents were lost, but all the survey instruments and field material were saved. The rest of the project area was completed from Circle after the weather cleared up.

The crew that was working the central part of the Brooks Range finished at Umiat on the North Slope. They moved from Umiat into Fairbanks and then loaded their equipment on trucks and went to Chicken. The crew established horizontal and vertical photocontrol for 1:63,360-scale mapping of the Eagle 1:250,000scale quadrangle. Work progressed very well, except for some adverse weather. Several high

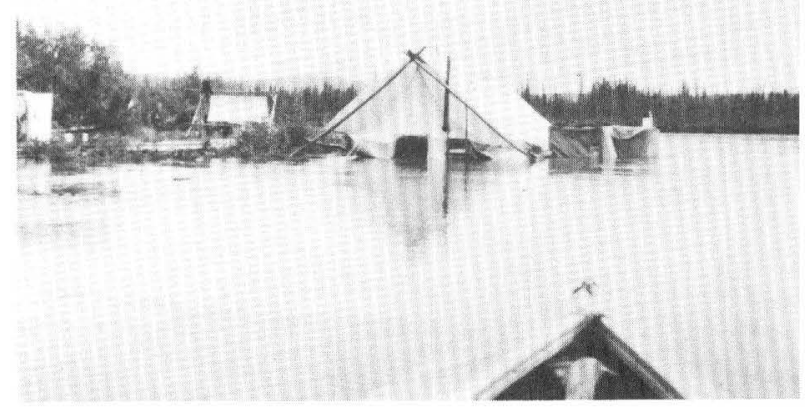

Camp on Black River, 60 miles east of Fort Yukon, during the flood caused by heavy rains in Canada (1956).

peaks in the area were seldom clear. One of the fieldmen was fogged in on one of the high peaks for several days and ran out of food. He was rescued and found in good condition but hungry. This crew finished their work around September 15.

The crew on the western side of the Brooks Range finished their work at a camp on the Killik River. From there, they moved to the village of Tanana, where they established the horizontal and vertical control necessary for 1:63,360-scale mapping to complete the Tanana 1:250,000-scale quadrangle. The work progressed rapidly, and they finished during the last week of August and moved their camp and equipment to Fairbanks. Both of their helicopters went to Chicken to help that crew finish their work. Two of the fieldmen went to the camps at Circle and Chicken.

About September 20, all the crews were done with their fieldwork, and the camps and equipment were moved to Fairbanks and stored in the warehouse. The field material was assembled and sent to Denver. The two men working on names and culture continued to work, with one of them staying until Thanksgiving.

The 1956 field season was one of the most productive seasons that the Survey has ever had in Alaska. Not only was the Brooks Range project completed early, but all the work scheduled for the 1957 season was completed.

\section{7}

No Alaska projects were scheduled for 1957. 
However, the Air Force 1370th Mapping and Reconnaissance Squad took advantage of one of the most cloud-free summers on record to obtain aerial photography to fill existing gaps in coverage over the St. Elias and Alaska Ranges and the Chugach and Wrangell Mountains.

\section{8}

The work scheduled for the 1958 season was mainly to finish fieldwork started in 1953 and 1954 on the southern side of the Alaska Range and to join the military work on the western side of the Alaska Range. The phototheodolite work on the southern side of the Alaska Range from Curry to Cook Inlet still had not been completed. Other fieldwork needing completion included vertical control on the Tyonek $1: 250,000$-scale quadrangle and horizontal and vertical control on the Iliamna, Lake Clark, Lime Hills, McGrath, Medfra, and Mount McKinley quadrangles.

One crew of five fieldmen and three field assistants with two helicopters started work on May 1 at Skwentna. Fieldwork was started early to take advantage of favorable weather in the Alaska Range to complete the phototheodolite stations. The snow was still deep on the foothills where the existing triangulation stations were located; but, with a lot of snow shoveling, the phototheodolite work was completed by June 1 . The altimeter work also was completed on the Tyonek 1:250,000-scale quadrangle, and the crew moved camp from Skwentna to Lake Clark the first week of June. From the camp at Lake Clark, the photocontrol work was completed on the Iliamna, Lake Clark, Kenai, and Lime Hills 1:250,000-scale quadrangles. These were only partial quadrangles because the military had controlled and mapped the western one-half of the quadrangles earlier.

On August 1, the crew moved from Lake Clark to Farewell, where camp was set up at the Federal Aviation Administration airstrip. The crew was at Farewell for most of August and completed the McGrath, Medfra, and Mount McKinley 1:250,000-scale quadrangles. The military had done the western one-half of these quadrangles; consequently, the crew was completing the area between the Survey work in 1953 and 1954 and the military work in 1952, 1953, and 1954.

Work was completed at the end of August. Part of the crew and both helicopters were sent ahead to Fairbanks to complete a portion of the Big Delta quadrangle. The crew was able to work from town, so a field camp was not necessary. The remaining crew at Farewell completed their field notes, packed the camp equipment, and moved to Fairbanks on a chartered C-46. The earlier moves from Skwentna to Lake Clark and from Lake Clark to Farewell were made with Bureau of Land Management and Fish and Wildlife Service Grumman Goose amphibian airplanes. The Bureau of Land Management was very cooperative with the Survey, and the crews were able to use their planes on a number of occasions. Often, if the Bureau had a plane going by one of the Survey camps, they would deliver groceries or personnel free of charge. If the crews needed them to move camps or to haul fuel or supplies, then the charge was only actual cost. The Survey used them whenever possible because it helped both agencies. The Fish and Wildlife Service planes also were used when possible.

The Survey did not have a plane on contract during this season, but the crews were able to charter a Cessna 180 on floats while at Lake Clark and a Super Cub while at Farewell. The airplanes were used to cache fuel for the helicopters and to make a trip to Anchorage once a week for groceries and mail.

The 1958 season was very good, considering the prevailing weather conditions of the area. The clouds that covered the Alaska Range most of the summer usually remained at the 3,500to 4,000-foot level. Many rainy periods each lasted several days, and the western side of the range was plagued by high winds. Later records referred to 1958 as having the wettest months on record for south-central Alaska. At Farewell, the wind seemed to be a constant 35 to 40 miles an hour with gusts on some days reaching 75 to 80 miles an hour. The crews were told by the Federal Aviation Administration people that the tents would never last through the season. Several times the stability of the tents was in doubt, but none of them blew down or ripped apart. 
The work scheduled for 1959 was a combination of photocontrol for 1:63,360- and $1: 250,000$-scale mapping. Only one crew, consisting of five fieldmen and two field assistants, was scheduled for fieldwork. Two helicopters were contracted for the season. Two men drove two trucks from Denver, and the rest flew to Anchorage.

The work started at Yakatat, and photocontrol was established for the 1:63,360-scale quadrangles. This was the first season that electronic distance-measuring equipment was used in Alaska to accomplish the horizontal and vertical control. The instruments had been used for 2 years on stateside projects. Electronic traverses were run by using the instruments to measure distances and the Wild T-2 theodolites to observe angles. The traverses were started from and tied to existing known positions. Simultaneous reciprocal vertical angles were observed over all measured distances. However, for some areas, the only feasible method for establishing vertical control was by altimeters.

After the work was completed in the Yakatat area, the crew moved to Yakataga. There, the crew worked on the Bering Glacier 1:250,000scale quadrangle. This area was very remote, with very little culture and few inhabitants. The fieldwork consisted of photoidentifying the existing International Boundary Commission control on the eastern side of the quadrangle. Horizontal and vertical control were established through the center of the quadrangle.

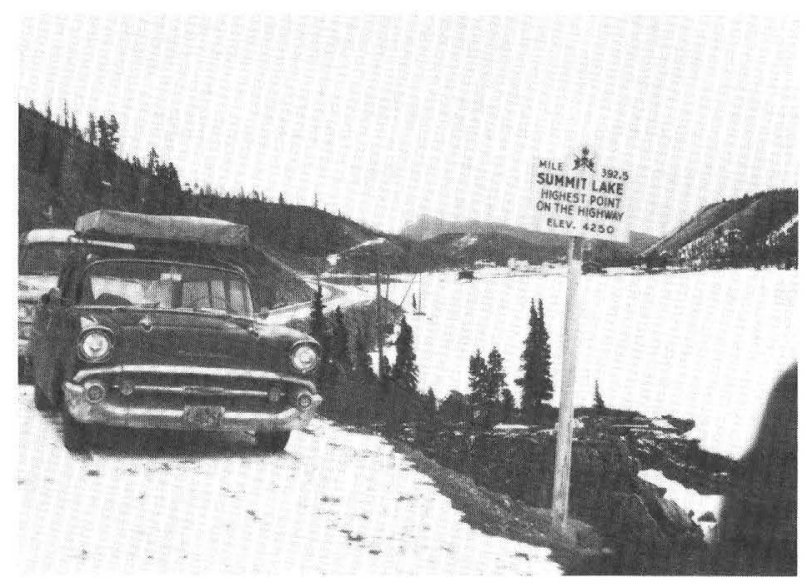

Driving the Alcan Highway to Alaska (1959).

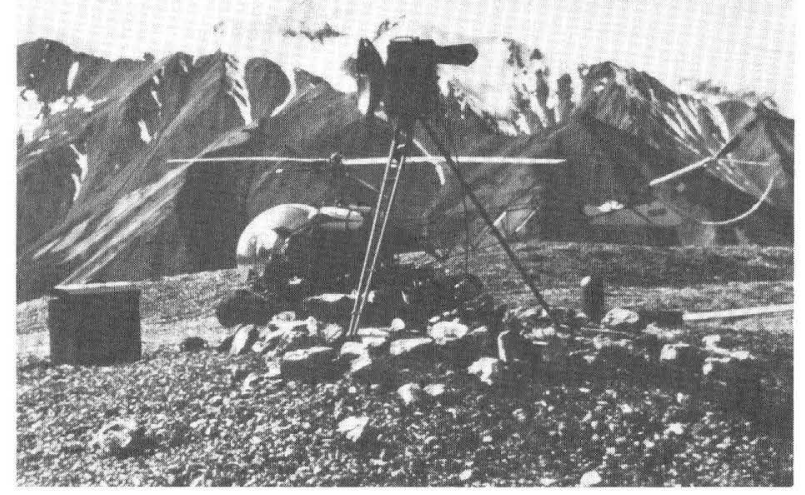

First electronic distance-measuring equipment in use at Bering Glacier (1959).

Using the electronic distance-measuring equipment, the crew completed a traverse from the coast on the south, over the Bering Glacier, and down the northern side to existing control in the Chitina River valley. The traverse was approximately 150 miles long. To control such terrain by triangulation would have been extremely difficult, if not impossible. The crew also established a number of phototheodolite stations in the St. Elias Range, working out of Yakatat and Yakataga.

The National Geodetic Survey also was establishing basic control simultaneously with our work. The Geological Survey and the National Geodetic Survey field camps were set up side by side at Yakataga.

After this work was completed, the crew moved to McCarthy to establish horizontal and vertical control for the 1:63,360-scale maps for the McCarthy and Nabesna quadrangles. This area is almost as rugged as the Bering Glacier area. The Wrangell Mountains run east and west along the northern side of the McCarthy quadrangle and the southern side of the Nabesna quadrangle. From McCarthy, an electronic traverse was established over the top of the Wrangell Mountains to existing control along the Slana-Tok Highway. After the work on the southern side of the Wrangell Mountains was completed from McCarthy, the crew moved to Chisana to complete the area on the northern side of the mountains.

This was a very good season, considering the terrain and weather conditions around the 


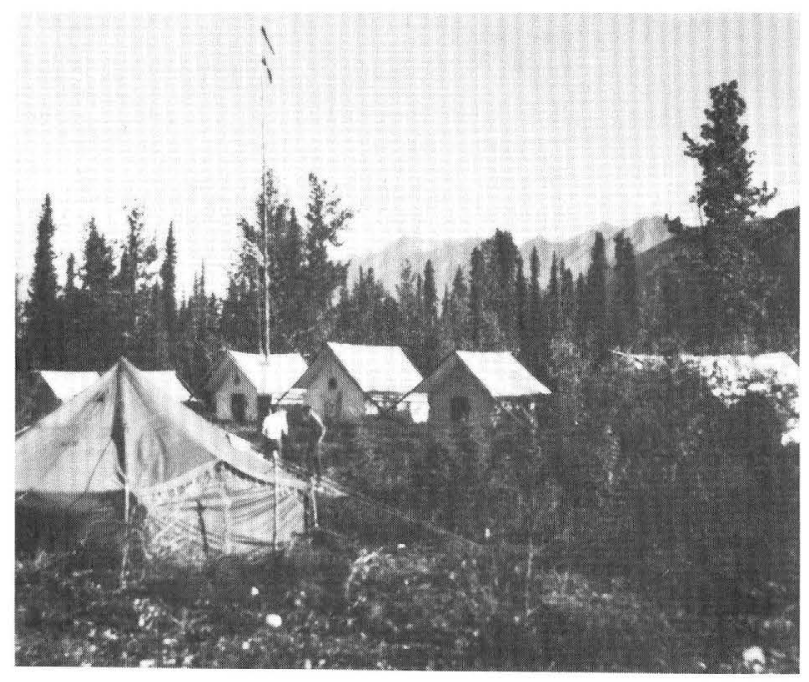

Camp at Chisana, Wrangell Mountains (1959).

glaciers and high peaks. The project area contained elevations ranging from sea level to 18,000-foot Mount St. Elias on the Canadian border.

\section{0}

One crew was scheduled for the 1960 field season. The plan was to complete all the gaps that had not been covered by aerial photography before 1957. In addition, work was scheduled for the Juneau Ice Cap and an area just east of Petersburg. By using the phototheodolite, altimeter, and electronic traverse procedure and the higher altitude capabilities of the newer Bell G-3 and Hiller 35-E helicopters, the plan was to complete the most inaccessible areas left to map in Alaska (and North America)-inaccessible because of extensive cloud cover and high altitudes.

The season started at Northway to complete several 1:63,360-scale quadrangles on the Nabesna, Gulkana, Valdez, and McCarthy $1: 250,000$-scale quadrangles. The area was completed in 2 weeks, and the crew moved camp to Chistochina, where they stayed at a roadhouse while working the area to the east of Mount Drum and Mount Sanford. During the move to Chistochina, one of the helicopters had a clutch failure while landing at an elevation of 7,500 feet. Repairs were made during a fierce snowstorm that deposited 4 feet of snow on the ground.
The work at Chistochina was completed in 2 weeks, and the crew moved to Sheep Mountain Roadhouse on the Glenn Highway. From there, the crew established electronic traverse positions to support phototheodolite and altimetry photocontrol in the Chugach Mountains because the previous control along the Glenn Highway was not suitable for helicopter landing or phototheodolite work. This is a very bad weather area. The peaks are fogged in most of the time, and the whole area is covered by large glaciers and snowfields.

The next 2 weeks were spent in Valdez controlling the remainder of the Anchorage and Valdez quadrangles, which cover the highest elevations of the Chugach Mountains around Mount Marcus Baker.

The crew then moved to Juneau, where they were to finish controlling those portions of the Skagway, Mount Fairweather, Juneau, Atlin, Taku River, Petersburg, and Sumdum quadrangles that were most inaccessible and covered by ice. Camp equipment was shipped to Juneau, but, because camp work was not required, the equipment was eventually sent to the National Park Service at Gustavus, Glacier Bay National Park, for storage and use the following season. The work in controlling the Juneau Ice Cap was completed, but the work at Mount Fairweather and Sumdum-Petersburg was left for the next year because of the lateness of the season and adverse weather.

In spite of the moving and adverse weather in the Chugach Mountains, it was a successful season. The helicopter crew was very good,

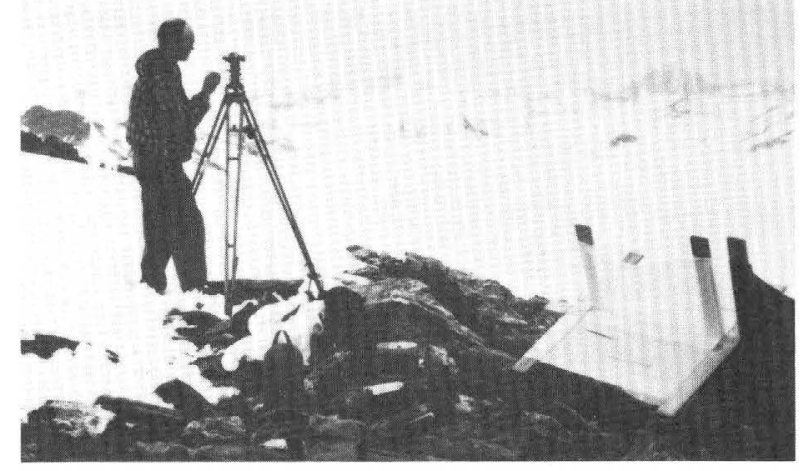

R. E. Isto, the Survey's first Alaska Resident Engineer, on the Juneau Ice Cap (1960). 
and the ships performed well. Additionally, one drove up the Alcan Highway and field completed several military-compiled maps east of Anchorage. He also hauled supplies to the field crew when they were at Chistochina and Sheep Mountain.

\section{1}

The area scheduled to be worked during the 1961 field season was west of Juneau in the coastal mountains between Glacier Bay National Park and the Pacific Ocean and from Mount Fairweather in the north to Icy Straits in the south. The area was not very large, but the weather was very bad. The warm air off the water and the cold air from the large glaciers combined to produce mist and fog.

The field and helicopter crews arrived in Juneau, and arrangements were made to establish a tent camp at Reid Inlet on the western side of Glacier Bay. The project started about the first week of June. Because of poor weather conditions and the high altitudes, the crew spent most of the season working this one area. They also spent some time working out of Petersburg, finishing control on the Sumdum and Petersburg quadrangles.

In rugged areas such as this, where all the work was done with helicopters and the weather conditions were bad, the crew expected to work only about 30 percent of the time. It takes a lot of patience to spend a season in wet and cold tents waiting for a day to work. The work was completed about September 1, and the crew packed all the equipment and shipped it back to Fairbanks.

The original Resident Engineer in Fairbanks was transferred to the Region office in Denver and was replaced by one of the project engineers from the Rocky Mountain Region. The new Resident Engineer spent the entire summer season in Alaska with the former Resident Engineer getting acquainted with people from other Government agencies and State and local agencies. The transition was smooth, and the moves by both men were accomplished during the fall season.

\section{2}

The 1962 field season was the beginning of another innovation in Alaska mapping. The area around Anchorage was selected for a special 1:24,000-scale Anchorage and vicinity map. Because the map was to be published as a special, the map projection was selected to cover the town and the populated area surrounding the town.

The crew arrived in early June to start work on the project. The crew lived in town, and, consequently, no camp equipment was needed. Methods for establishing horizontal and vertical control were the same as those used for 7.5minute quadrangle mapping in the conterminous United States. The work progressed very well and was completed about the first part of October. The helicopter work was done by charter through a local operator.

This special map had not been published when a devastating earthquake occurred on Good Friday in 1964 but was ready for shipment to Washington to be printed when the earthquake hit. The decision was made to publish the map as compiled, rather than attempt to show the changes created by the earthquake. A statement was added to the map margin indicating that the culture and contours were preearthquake.

\section{3}

The area to be worked during the 1963 field season was another cleanup-type project. The area was the Alaska Peninsula, which the Army had worked in 1953 but did not complete because of lack of aerial photography. A shortage of funds at the end of the 1963 fiscal year postponed the start of work until July 1. A threeman crew left Denver on June 15 and flew to Anchorage. Several days were spent in Anchorage getting equipment ready to ship to Port Heiden, which is on the Bristol Bay side of the Alaska Peninsula. The men and equipment arrived in Port Heiden the last week in June, and the helicopters arrived on July 1.

Peninsula weather conditions are generally poor, with considerable fog and rain. Also, very high winds make flying treacherous. When work was completed around Port Heiden, the crew moved to Cold Bay, which is located at the southwestern end of the Peninsula. The weather gets worse the farther west you go toward the Aleutian Islands. 
Instead of tents, the crew was able to stay in buildings in Port Heiden and in a transient hotel at Cold Bay. These facilities were a real convenience because the tents were hard to maintain and keep dry in the constant wind and rain. After a wet and windy season, the work was completed in early September without any accidents or injuries. All the equipment and instruments were returned to Anchorage, and the personnel returned to Denver.

\section{4}

No projects were scheduled for the 1964 season in Alaska. However, after the earthquake on Good Friday, March 27, the Geologic Division requested help in determining the damage in certain areas. Two men were detailed from Denver and reported to the Resident Engineer in Anchorage. The men spent about 2 weeks in Anchorage doing 1-foot-interval topography on the Turnagain Slide. The work was com- pleted around the middle of May.

On June 1, another fieldman was detailed to Anchorage to assist the Resident Engineer on another request from the Geologic Division. This was an unusual request because the work involved future earthquakes. The geologists had selected approximately 15 large lakes on which they wanted permanent bench marks set and a difference of elevation determined between the bench mark and water level. All the bench marks for a lake were set on the same day. Depending on the size of the lake, at least three bench marks were set on each lake, and up to five or six bench marks were set on the large lakes. The lakes were within a 400 -mile radius of Anchorage.

A floatplane was chartered and supplied with a gas-driven drill, cement, and bench mark tablets. Some of the lakes could be reached from Anchorage, so the work could be completed during the same day. Others on the Alaska Peninsula and Kodiak were too far to

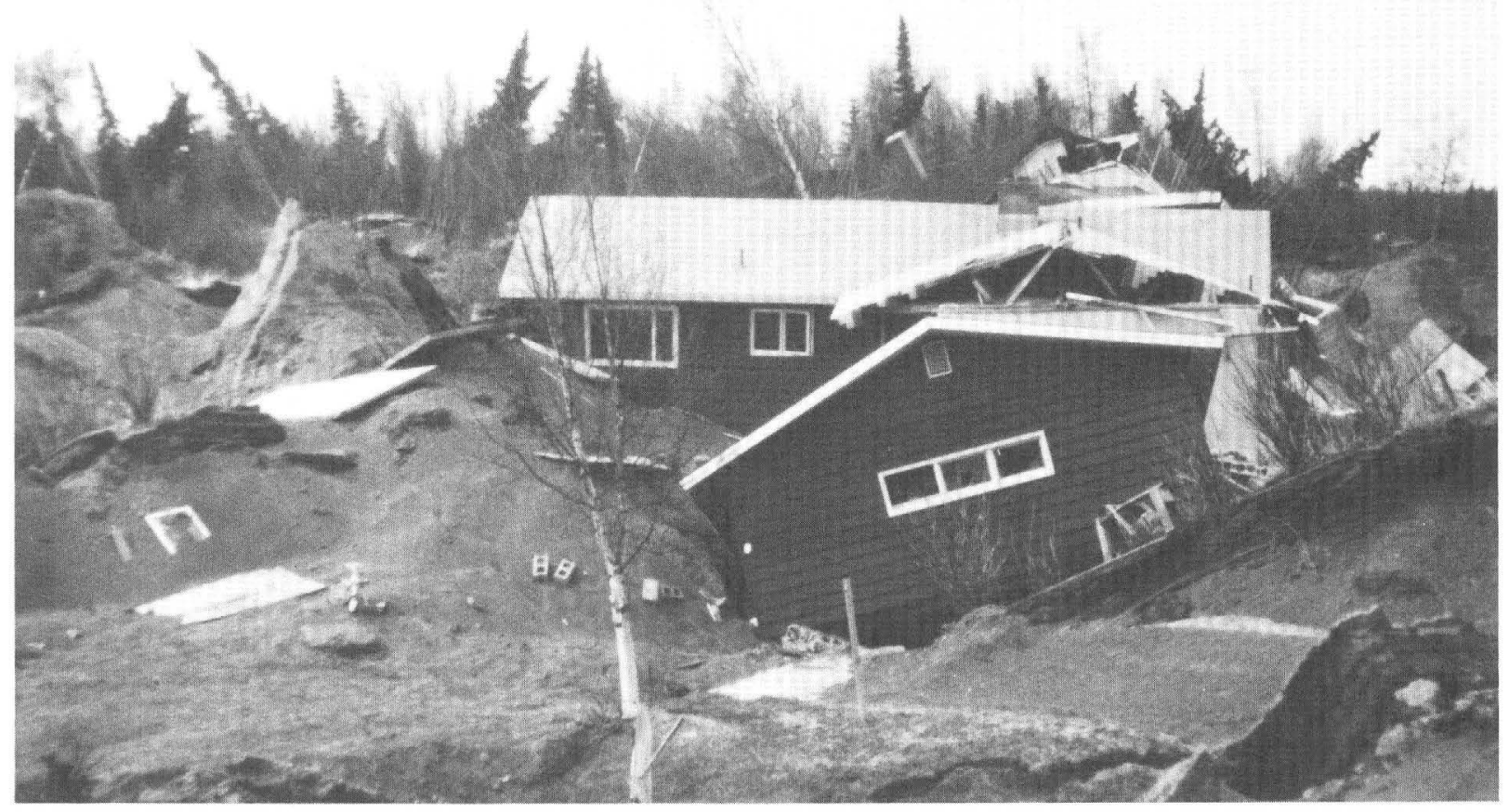

Damage from the Good Friday earthquake near Turnagain Slide (1964). 
commute to from Anchorage, so arrangements were made to stay at lodges while working in those areas. Because of weather conditions, it took about 6 weeks to complete the operation.

The theory of setting the permanent bench marks and measuring the difference of elevation between the bench mark and water level is analagous to using the lake as a spirit-level bubble to determine tilt. In the event of another devastating earthquake, these differences of elevations can be remeasured to determine if any tilting has occurred in the area.

\section{5}

No regular mapping projects were scheduled for the 1965 season, but the Office of Special Projects in the Geologic Division requested our assistance in a geologic study on Amchitka Island. The Atomic Energy Commission was preparing to detonate their first nuclear device on Amchitka, and geologists were responsible for measuring the tectonic strain created by the blast. After discussing the project with the geologists in Denver, a plan was devised to gather information for their studies.

One man left Denver in early October and reported to the Resident Engineer in Anchorage and then proceeded to Amchitka to do the predetonation measurements. A level line was run over ground zero and for several miles on either side of the site. Permanent bench marks were set around ground zero to several miles away, and horizontal distances were measured with a geodimeter.

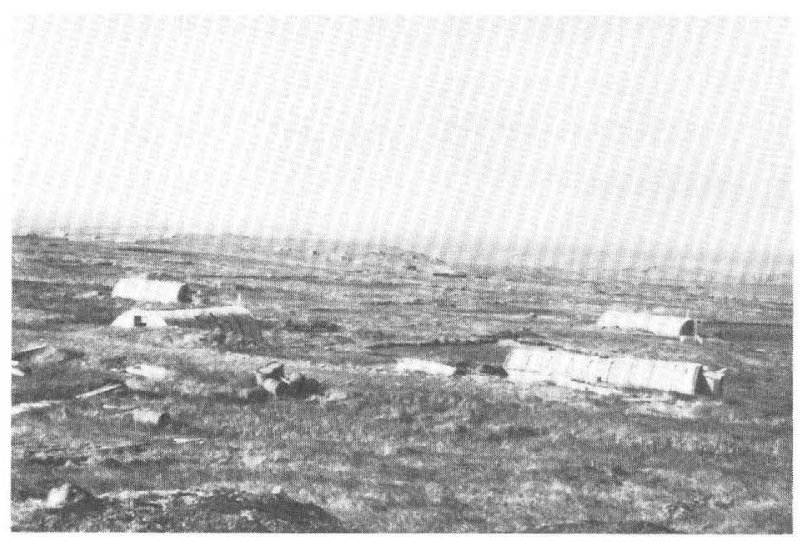

Amchitka Island showing quonset huts left from World War II (1965).
After the nuclear device was detonated, levels were rerun and the distances remeasured to determine what changes had occurred.

The project was completed in early November, and the fieldman returned to Denver.

\section{6}

A small project, consisting of five 1:24,000scale quadrangles, was scheduled for the 1966 season to map the city of Fairbanks and the surrounding area. This was the first 1:24,000scale project in Alaska to be published in regular quadrangle format. The Fairbanks quadrangles were 7.5 minutes latitude by 15 minutes longitude and were designed as quarters of the 1:63,360-scale quadrangles.

Three men drove from Denver and joined the Resident Engineer in Fairbanks to make up the crew. Work started in early June. The project was handled in the same manner as the special Anchorage and vicinity map. The horizontal and vertical control was established according to standards used for 7.5-minute mapping in the lower 48 States. Classification of culture was completed on $2 \mathrm{X}$ enlarged photographs. Very little helicopter time was required on the project.

The work was completed in early September, and the men drove back to Denver.

\section{7}

No Alaska projects were scheduled in 1967. A flood occurred in Fairbanks that left water-

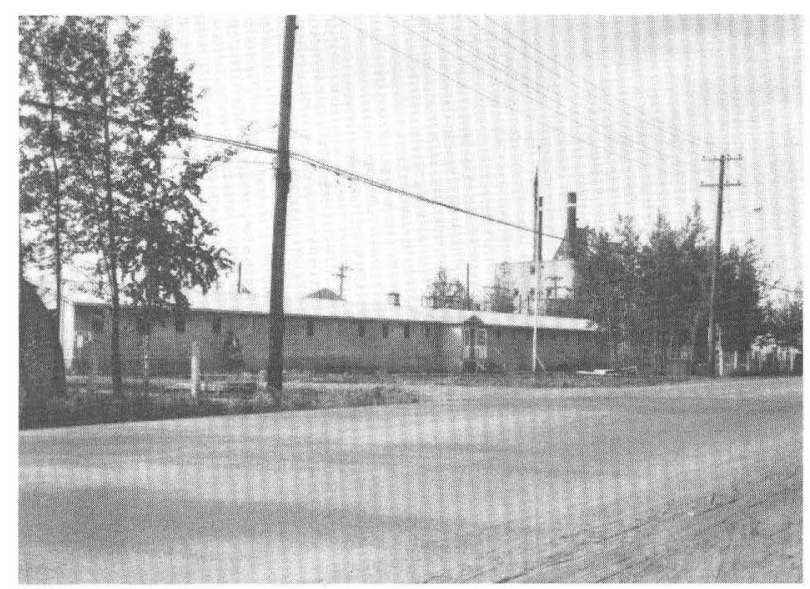

Geological Survey office in Fairbanks before the 1967 flood. 
marks near the top of four-drawer-high map filing cabinets in the Resident Engineer's office. Many hours were spent drying the maps that contained correction information for map reprinting. Some damaged records were sent to Seattle for special renovation.

\section{8}

No Alaska projects were scheduled in 1968. The Resident Engineer in Fairbanks was transferred to Denver in the spring, and a new Resident Engineer was assigned to Alaska. The Resident Engineer's office was moved from Fairbanks to Anchorage in January 1969.

\section{9}

No standard mapping projects were scheduled for Alaska in 1969. The Office of Special Projects, Geologic Division, again requested assistance at Amchitka Island to measure the tectonic strain from another device to be detonated by the Atomic Energy Commission.

The Survey had completed several projects at the Nevada Test Site and had acquired more experience on how to position the test areas to provide better overall information on the movement caused by the underground blast. The instrumentation was the same as that used in 1965 at Amchitka, except the geodimeter had a laser beam, and measurements were made easily in daylight. The first geodimeters had an incandescent light that had to be operated at night to measure any distance over one-half mile.

In October, three men were sent from Denver to do the predetonation measurements. When the predetonation work was done, the crew returned to Denver. Two weeks later, after the device had been detonated, two men returned to Amchitka and remeasured all the courses to determine the extent of the tectonic strain. Work was completed in early November.

\section{0}

After the oil discovery at Prudhoe Bay in 1968 , the interest in building a pipeline became very real. In 1969, the area covering the socalled transportation corridor was authorized for mapping at 1:63,360 scale. This corridor extended from the Yukon River in the south to Prudhoe Bay in the north. The area south of the Yukon River already had 1:63,360-scale map coverage from previous projects, whereas north of the Yukon River only the 1:250,000-scale maps existed.

An aerial photography contract was awarded for new vertical photographs covering the project area. Flying started when the snow had melted and was completed in early September.

One field party left Denver in early May for Fairbanks. Camp equipment was assembled at a warehouse in Fairbanks and shipped by air to Bettles, where the Resident Engineer had made arrangements to build a camp on the western side of the airstrip. During the winter, the Resident Engineer had driven a small jeep to Bettles over the Hickel Highway and across an ice bridge over the Yukon River for use at camp to haul fuel, water, and supplies. The camp was set up and ready to start work on June 1 when the helicopters arrived.

Before the helicopters left Fairbanks, two men used the helicopters for 2 days to observe simultaneous reciprocal vertical angles between existing horizontal control stations from Fairbanks to the Yukon River. During the field season, vertical angle observations were continued along the existing National Geodetic Survey triangulation arc from the Yukon River through Bettles and north toward Anaktuvuk Pass. The work was continued the following year to complete a continuous simultaneous reciprocal vertical angle traverse from a first-order level line at Fairbanks to a tidal bench mark at Point Oliktok on the Arctic Ocean. This traverse was 600 miles long.

The crew worked all season from the camp at Bettles. The work progressed very well in the lowlands south of Bettles, but, in the mountain areas north of Bettles, progress was slow due to the clouds that lay around the peaks at about 3,500 feet.

While most of the crew remained at Bettles, some members went to Prudhoe Bay for a week with the two helicopters and established control for twelve 1:24,000-scale orthophotomaps. Arrangements were made with an oil company for room and board. Exceptionally good weather prevailed, and the project was completed in 5 days, after which the crew returned to Bettles. 


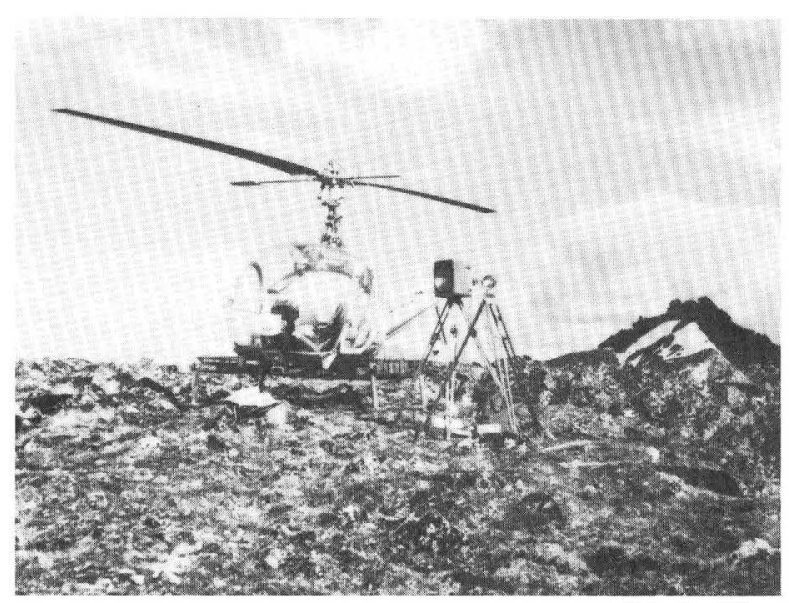

Hiller 12-E helicopter, electrotape, and signal light on a map control point south of Bettles (1970).

By August 15, all the work that could be done efficiently from Bettles was completed. Because of adverse weather and snow on the higher peaks, the decision was made to terminate the season rather than to set up another camp at Chandalar Lake. The time and expense to move a camp that late in the season would not have been offset by the work that might have been accomplished in the Brooks Range. The crew moved camp and equipment to Fairbanks, stored everything in the warehouse, and returned to Denver.

\section{1}

The work scheduled for the 1971 season was a continuation of the work started in 1970 along the transportation corridor. Two crews were selected, and four helicopters were contracted for the season. A Turbine-Beaver also was contracted to supply the two camps.

One camp was set up at Chandalar Lake, and one camp, at Wiseman. C-130 Hercules airplanes were chartered to transport the camp equipment and fuel from Fairbanks to Chandalar Lake. The Turbine-Beaver was used to transport the camp equipment from Chandalar Lake to the Wiseman camp because the airstrip at Wiseman could not handle a C-130 airplane.

The weather during June was favorable in the Brooks Range; both crews finished the map control on the southern side of the Range and were ready to move about the end of June. The crew at Chandalar moved to a sandbar on the
Ribdon River near Elusive Lake, on the northern side of the Brooks Range. The Wiseman crew moved to a small dirt strip built on a sandbar in the Itkillik River, about 50 miles north of Anaktuvuk Pass.

Both camps were moved with the TurbineBeaver because the landing areas at the camps would not accommodate anything larger. Fuel for both camps was purchased at Sagwon and hauled to the camps in the Turbine-Beaver. The crew at Ribdon River had two turbine helicopters that used jet fuel. The Turbine-Beaver could haul four drums at a time. The crew at Itkillik had piston-engine helicopters and used aviation gasoline. The Turbine-Beaver could haul approximately forty 10 -gallon cases of aviation gasoline in a trip.

The weather was exceptionally good on the northern side of the Range, and the work progressed quickly. The area scheduled for the season was completed during the last week of July.

The day before the crew at Itkillik was to move camp, a very strong wind came up and blew the tents down, destroying some of them. The Turbine-Beaver brought the men into Sagwon, where they stayed until they could return to Itkillik and bring the instruments and camp equipment to Sagwon. The camp at Ribdon River also was hauled in to Sagwon. After all the equipment was brought in, a C-46 transport airplane was chartered to haul the equipment to Fairbanks.

The camp equipment was stored in the warehouse at Fairbanks, and the crew returned to Denver during the first week of August.

\section{2}

The Air Force had acquired new aerial photography during 1970 and 1971 over several areas of Alaska, including the northeastern section of Alaska covering the Arctic, Table Mountain, Mount Michelson, and Demarcation 1:250,000-scale quadrangles. The project scheduled for the 1972 season joined the transportation corridor work done in 1970 and 1971 and extended east to the Canadian boundary. The project area covered both sides of the Brooks Range at the highest part of the range. Some of the worst weather in northern Alaska exists in this extreme northeastern corner of the 
State. Storms build along the Arctic coast and move into the mountains, making the northern side of the range very difficult to survey because of the fog and high winds.

One crew was sent from Denver to Fairbanks in June. The crew consisted of six men and two field assistants. Camp equipment was assembled and hauled to Arctic Village by air, and a camp was set up along the airstrip. Three helicopters were contracted for the season and reported for duty on July 1 . The chief pilot, who came from the Deep South, enlivened camp cooking with his Cajun gumbo made with northern pike and seasoning he was able to find in Fort Yukon.

Most of the project was worked from the base camp at Arctic Village, but a temporary camp was set up at Peters Lake on the northern slope. The temporary camp was needed because it was impossible to predict what the weather conditions would be on the northern side of the range from the camp in Arctic Village. Most of the work on the northern slope was completed from the temporary camp.

A considerable amount of electronic traverse was established to obtain the necessary photocontrol and to make horizontal ties between the National Geodetic Survey triangulation arc that extends from the Yukon River to the Arctic Ocean through Anaktuvuk Pass and to the International Boundary. During 1970, 1971, and 1972 , this large area, which covers the eastern one-half of the Brooks Range, was controlled with electronic traverses with ties to National Geodetic Survey arcs on all sides. This enabled the whole area to be computed under a unified adjustment.

Work was slow on this project because of the weather and the large area to be covered. The addition of a third helicopter did not prove to be as successful as had been hoped. Helicopter operations should be used in pairs to be efficient. The high country was completed, but not some of the area on the southern side of the project. The weather was poor, and the helicopter contract had expired. Because of the uncertainty of the weather, the decision was made not to extend the helicopter contract, so the camp was closed, and the equipment and materials were shipped back to Fairbanks. The crew returned to Denver during the second week in September.
The season of 1973 included the first mapping done by the Survey in metric units. A project consisting of 31 quadrangles covering Anchorage and surrounding built-up areas was selected for mapping at 1:25,000 scale with metric contours. The contour intervals ranged from 5 to 20 meters, depending on terrain. Actually, three different projects were included in the 31 quadrangles-complete revision covering the city of Anchorage, new orthophotomaps for selected quadrangles, and standard topographic maps for the remainder.

New aerial photography was flown during the 1972 season. The control planning was completed during spring 1973, in the same manner as a 7.5-minute quadrangle project in the lower 48 States. Photographs covering the city and other heavily developed areas were enlarged for classification work. The Resident Engineer in Anchorage had consulted with the local agencies and obtained the necessary boundary information concerning city limits, parks, military reservations, and other data pertinent to mapping. Six men were selected to work the project. Because of the amount of ground work required for this project, each man needed a vehicle. Six new carryalls were leased from the motor pool in Denver and loaded with all the field material and instruments necessary to do the project.

The crew left Denver on May 14 and drove to Anchorage, arriving about a week later. The men were able to rent good housing in Anchor-

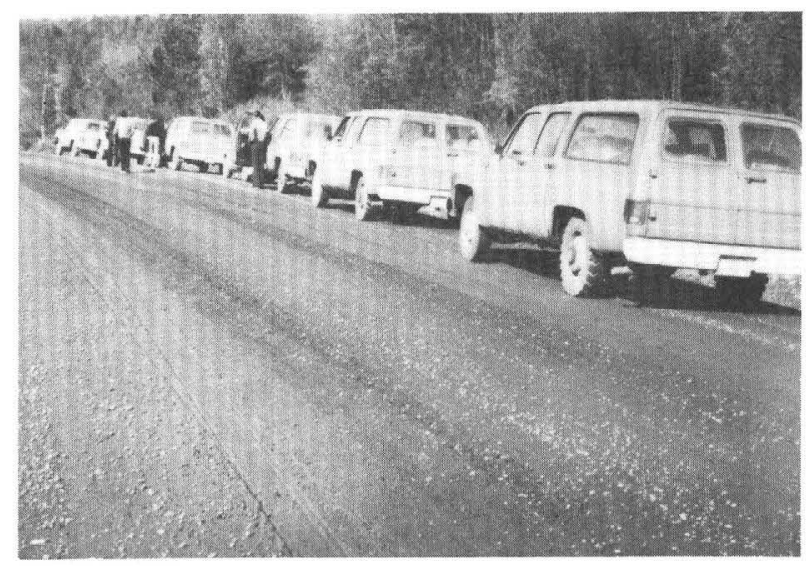

Survey convoy on the Alcan Highway en route to Anchorage (1973). 
age and were ready to begin work immediately. The Resident Engineer had obtained the necessary office and storage space. A helicopter was contracted from a local operator and was based at the contractor's hangar at one of the local airports in town, so fuel and mechanical maintenance were available. Also, during flight operations, the pilot was in constant radio contact with his home base as well as with the control tower at the airport, which made for a safer operation than was usually available in the remote camps.

This was a very relaxed project because the crew worked a regular 5-day week and did not have the constant pressure of a camp. No logistics problems, such as fuel for helicopters and aircraft, mail for camp, and food supplies, were encountered. The work progressed very well and was completed in early September. The crew loaded all their vehicles and returned to Denver during the first week of September.

\section{4}

No Alaska projects were scheduled in 1974.

\section{5}

No Alaska projects were scheduled. The Resident Engineer in Anchorage transferred back to Region headquarters in Denver. The office in Anchorage was vacant until late summer, when another Resident Engineer was assigned. The new Resident Engineer worked on completing the loose ends of the Anchorage mapping.

\section{6}

The Bureau of Land Management office in Anchorage requested help in establishing horizontal control to support cadastral surveys with their inertial guidance system. The areas that they needed help with were near Chandalar and on the Hughes, Survey Pass, Shungnak, and Ambler River 1:250,000-scale quadrangles. The area at Chandalar was a small project, and two men worked from Fort Yukon with two helicopters establishing horizontal control by electronic traverse methods. Because of poor weather and considerable snow, the project took longer to complete than planned. The men completed the Chandalar work about June 20 and reported to the camp at Dahl Creek, where the rest of the crew were set up to work the other area. Along with establishing control for the Bureau of Land Management's boundary surveys, the crew also established photocontrol for the Geological Survey mile-to-inch quadrangle mapping on the Hughes, Shungnak, and Ambler River quadrangles. All the work for the Bureau of Land Management was completed, and horizontal and vertical control was completed on the Shungnak quadrangle. Horizontal control on the Hughes quadrangle was completed, but not the vertical control because of adverse weather and expiration of the helicopter contract.

This was the first season that the Survey had helicopters contracted through the Office of Aircraft Services. The Office of Aircraft Services was established by the Department of the Interior several years earlier to handle all the contracting of helicopter and fixed-wing aircraft for Interior agencies. Office personnel made several inspection trips to camp and had only minor complaints concerning Survey operations. Considerable work was accomplished, and this was a very good season. The camp equipment was returned to the warehouse in Fairbanks, and the crew returned to Denver in early September.

\section{7}

Four small projects were scheduled for the 1977 field season. The areas, to be controlled for 1:25,000-scale metric mapping, were at Cordova, Valdez, Whittier, and Seward. Two men from Denver and the Resident Engineer in Anchorage were assigned to do the fieldwork, supported by a Hiller 35-E helicopter.

The first area to be worked was Cordova. The crew arrived there in early June. Two trucks were shipped by Alaska State Ferry from Valdez, and the helicopter arrived about 10 days later. Several delays occurred while the helicopter was being certified.

After the helicopter arrived, it was plagued by mechanical troubles, and considerable time was lost. Just as the helicopter reached Cordova, a clutch failure, similar to what happened in 1960, necessitated an emergency landing on Eyak Lake. With the normal bad weather and 
the helicopter troubles, fieldwork in this project area was delayed. When the work finally was completed and the crew was ready to move to Valdez to begin the second project, the State Ferry system was on strike. Consequently, one of the trucks had to be left at Cordova. The crew was aware that a strike was imminent and had sent two trucks ahead.

Work started about the first part of August on the Valdez project. Progress was slow on this project also. The normal bad weather hampered flying in the higher mountains that surround the town, and record snowfalls the previous winter hampered the recovery and photoidentification of control. When the fieldwork finally was completed in September, it was too late in the season to attempt working the Whittier and Seward areas. Helicopter operations, therefore, were terminated, and the crew returned to Denver.

\section{8}

One small area, consisting of four 1:25,000scale quadrangles east of Willow and joining the northern edge of the Anchorage project, was authorized for mapping. The area was selected to provide larger scale map coverage for a possible new State capital for which the people of Alaska had voted.

In conjunction with the fieldwork for these four quadrangles, the Bureau of Land Management had requested help in establishing horizontal control for their inertial guidance system for surveying the boundaries of State withdrawal lands in the Alaska Range. The Bureau of Land Management project area extended from Mount McKinley in the north to an area west of Iliamna Lake in the south. Control stations were requested on both sides of the Alaska Range. Because of the inaccessibility of some of the requested stations, the Survey acquired two satellite tracking instruments to use in conjunction with the electronic distancemeasuring equipment. The Bureau of Land Management had been using the satellite tracking equipment for several years with varying degrees of success.

These instruments track Navy navigation satellites. Two methods are available for establishing a geodetic position from the satellites. One method is called point positioning. When using this method, only satellites that have the precise ephemeris programmed into their systems are tracked. Normally, it takes from 7 to 9 days to acquire a sufficient number of satellite passes to establish an acceptable position. The other method, which the Bureau of Land Management and the Survey use, is called translocation. In this method, one instrument is placed on a known horizontal position, and the other instrument or instruments are set on the requested points. All satellites (5) then are tracked, and usually a sufficient number of passes are acquired to establish an acceptable position within 36 to 48 hours.

Four men left Denver about May 20 for Anchorage. The Resident Engineer in Anchorage had made arrangements to base field operations for the Willow project in Talkeetna. Because arrangements were made at one of the local motels for meals and lodging, a camp was not necessary. One helicopter was contracted and reported for duty about June 1. Photocontrol for the Willow project was completed in about 10 days.

The crew moved from Talkeetna to Skwentna where they found that the former Federal Aviation Administration station had been converted to a borough school. Considerable other changes were noted from what had existed in 1954. A camp was set up, and work began on establishing control for the Bureau of Land Management. The whole season was plagued with malfunctions of the satellite tracking equipment. The season also had very bad

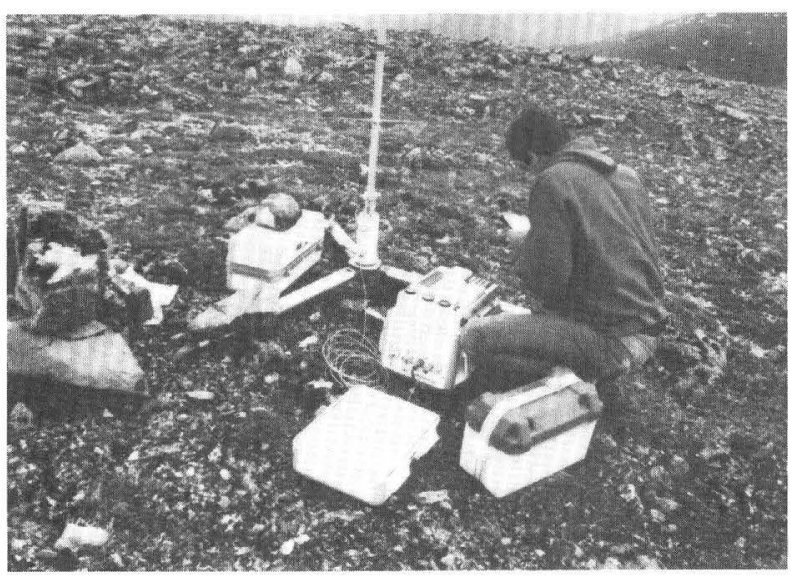

Satellite tracking instrument used for establishing geodetic positions from satellites. 
weather and near-record rainfall. The fieldwork that could be done with electronic distancemeasuring equipment was completed, but the satellite tracking work was not finished.

About August 1, it became apparent that the Bureau of Land Management work was not going to be completed, so two men left camp and went back to Talkeetna to finish the field classification work on the Willow project, which took about a week. Upon completing the Willow project, they then went to Seward and did the field classification work on the Seward project, which originally had been scheduled in 1977.

The skeleton crew left at Skwentna finished what work could be done, then closed the camp, and moved to Anchorage, where they worked on establishing photocontrol for the Whittier project. The crew worked until the helicopter contract expired.

A radio repeater was purchased in early spring for use on this project. The repeater was set up on Beluga Mountain and performed very well. The crew at Skwentna had direct radio contact with the Resident Engineer in Anchorage and with the helicopter in most areas of the project.

In spite of all the equipment failures and bad weather, considerable work was accomplished by moving around and picking up unfinished projects. Work was shut down about September 1, and the crews returned to Denver.

\section{9}

Two crews were selected to work in Alaska for the 1979 summer season. Contracts were let for helicopters and one fixed-wing airplane. Two helicopters were assigned to each crew, and the airplane was used to supply the camps. The airplane also was used to take photographs of the paneled stations and to move camps.

One crew was to complete the requested control for the Bureau of Land Management in the Alaska Range. Their camp equipment and supplies were transported by chartered aircraft from Anchorage to Farewell. The Resident Engineer in Anchorage had made arrangements with the Federal Aviation Administration and State authorities to set up camp at Farewell along the airstrip.

The Survey had purchased four new satellite tracking instruments, which were used in conjunction with the electronic distance-measuring equipment to complete the Bureau of Land Management work. The four instruments increased production tremendously, and work was completed at Farewell in about a month. The crew then moved to a camp at the Sparrevohn Air Force station and continued work along the western side of the Alaska Range. When the work was completed at Sparrevohn, the camp was broken up, and two men and the helicopters moved to Port Alsworth, on Lake Clark, to finish the Bureau of Land Management control around Illiamna Lake.

The remainder of the crew moved the camp equipment back to Anchorage and then to Seward to complete the photocontrol. When the two men at Port Alsworth finished their work, they also moved to the Seward project with the helicopters. Work was completed about the first week of September.

The second crew was to establish horizontal control in two areas for the Geological Survey's Special Mapping Center. One area was near Fort Yukon and consisted of photoidentifying existing control. This control was paneled, and photographs were taken from the helicopters and the fixed-wing airplane with a $35-\mathrm{mm}$ camera. While the crew was at Fort Yukon, two field assistants set up a camp at Dahl Creek. The work was completed at Fort Yukon in approximately a week, and the men and instruments moved to Dahl Creek, 5 miles north of Kobuk.

Additional horizontal control had to be established in this area. The control was established by using electronic distance-measuring equipment and satellite tracking instruments. Existing control also was paneled, and photographs were taken from the fixed-wing airplane. While the crew was at Dahl Creek working on the control for Special Mapping Center, they were able to finish the vertical control and classification work on the Hughes 1:250,000-scale quadrangle that had been started during the 1976 season.

All the work was completed at the Dahl Creek camp about August 1, and the camp equipment was shipped back to the warehouse in Fairbanks. The field assistants were paid off, and the crew moved to Palmer. One helicopter was loaned to the Water Resources Division in 
Anchorage. From Palmer, the crew established several horizontal control points in the Talkeetna Mountains that had been requested by the Bureau of Land Management. About onehalf the points were established by electronic distance-measuring equipment, and the remainder, with the satellite tracking instruments. After a week in Palmer, the crew moved to Alyeska and completed the horizontal and vertical control plus the classification work on the Whittier project.

The Seward and Whittier projects were mapped at 1:25,000 scale with metric contours. Although crews moved around considerably between partially completed projects, this was a very good field season. Both crews completed work about the first week in September and returned to Denver.

\section{0}

One project was authorized for the 1980 field season. The project consisted of 34 quadrangles to be mapped at $1: 25,000$ scale with metric contours. The project area was on Kenai Peninsula, and the crew lived at Kenai. The Resident Engineer in Anchorage had made arrangements with the U.S. Fish and Wildlife Service for office space. Because the crew rented apartments, a camp was not needed.

Five men and families drove up from Denver, leaving about May 20 and arriving in Kenai a week later. While part of the crew was getting the project started, two men were sent to Circle, where they were met by another fieldman from Denver, to establish horizontal control for the Bureau of Land Management. The helicopter was sent to Circle and arrived on June 2. The work was accomplished with the satellite tracking instruments and was completed about June 17. The men and equipment returned to Kenai.

The horizontal and vertical control was established by various methods. The electronic distance-measuring equipment was used whenever possible, and the satellite tracking instruments were used for isolated points. The vertical control was established by vertical angles, planetable traverse, fly levels, and altimeters.

Mapping photographs were not available when the project started. The State had color photography flown in 1975 that covered the area. A set of these photographs was purchased and used to classify and identify the control. By the end of the season, new color-infrared photographs were available. Culture had changed considerably in some areas, which created a few problems, and the new photographs helped to resolve the problems.

The project progressed very well. Helicopter work was completed about the first week of August, and the contract was terminated. Part of the crew left about September 1 to return to Denver. Two men stayed to finish odds and ends and then returned to Denver in late September.

\section{1}

One project, which consisted of 26 quadrangles to be mapped at 1:25,000 scale with metric contours, was authorized for the 1981 field season. The project joined the southern part of the 1980 work and continued south along Cook Inlet to include Kachemak Bay. Homer, Seldovia, Port Graham, and other small fishing villages were in the project.

Four men and one field assistant were assigned to the project. One helicopter was contracted for the season, and a boat was chartered for a few days to use along the coastal areas where helicopter landings could not be made.

The crew left Denver about May 20 and drove to Alaska, arriving about a week later. The Resident Engineer in Anchorage had made arrangements for an office in Homer. The crew was able to rent apartments in Homer. The contract helicopter was based in Homer, and fuel was readily available. Consequently, no logistics problems were anticipated.

Fieldwork began about June 1. The weather was very good for about 3 weeks, and then the rains began. By the end of the summer, record rainfall had been measured for July and $\mathrm{Au}-$ gust. The crew took advantage of every break in the weather to establish the necessary photocontrol for mapping. Classification work was done when it was raining. All the work was completed except four quadrangles that did not have new mapping photography. During the season, a horizontal traverse was extended through some of the U.S. Army Corps of Engineers' control that had not been updated to the 


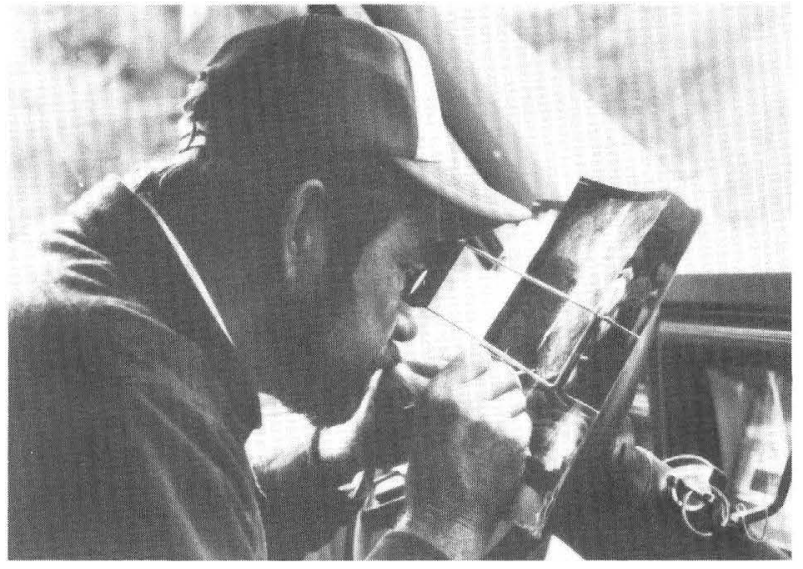

Field classification of mapworthy features in Alaska suburbia (1981).

1964 earthquake datum. In addition, control was established for a Water Resources Division flood-plain mapping project. Work was completed in late August, and the crew returned to Denver.

One small project was authorized for the 1982 field season. The mapping was requested by the State, and the project area extended from Willow in the south to Curry in the north. The area encompassed the Parks Highway and the railroad, plus the town of Talkeetna. The project consisted of eight 1:25,000-scale quadrangles.

Two men were assigned to the project and were headquartered at Talkeetna. The Resident Engineer in Anchorage had made arrangements for lodging and office space. The men flew from Denver to Anchorage on May 20. Their equipment was shipped from Denver and was in Anchorage when they arrived. Their vehicles, stored in Anchorage from the previous season, already had been checked and were ready to use. A helicopter had been contracted for about 3 weeks, starting on May 27. On Memorial Day, TV journalist Walter Cronkite, his wife, and a film crew of three visited the project to film Survey field operations for use on CBS" "Universe" program.

The fieldwork was routine and was accomplished without any major incidents. Approximately one-half the requested horizontal con- trol was established by using the satellite tracking instruments. The rest of the horizontal control was established by electronic traverse by using the electronic distance-measuring equipment. Fly levels were run along the Parks Highway and used as bases for altimetry. Also, the existing levels established by the National Geodetic Survey along the railroad were photoidentified and used to check the elevations on horizontal stations by simultaneous reciprocal vertical angles.

The weather was rainy during June and the first part of July. The crew took advantage of some marginal weather and were able to complete the project in late July. After completing the Talkeetna project, they moved to Homer and completed four quadrangles of classification work that the crew could not finish in 1981 because of the lack of new photography. This work was completed in a week, and the two men returned to Denver about the first part of August.

\section{3}

An ambitious program was authorized for the 1983 summer field season. In southeastern Alaska, fourteen 1:25,000-scale quadrangles in the Juneau area and two 1:25,000-scale quadrangles at Sitka were scheduled for mapping. In addition, satellite tracking observations for point positioning were planned for the interior and western Alaska to strengthen the overall

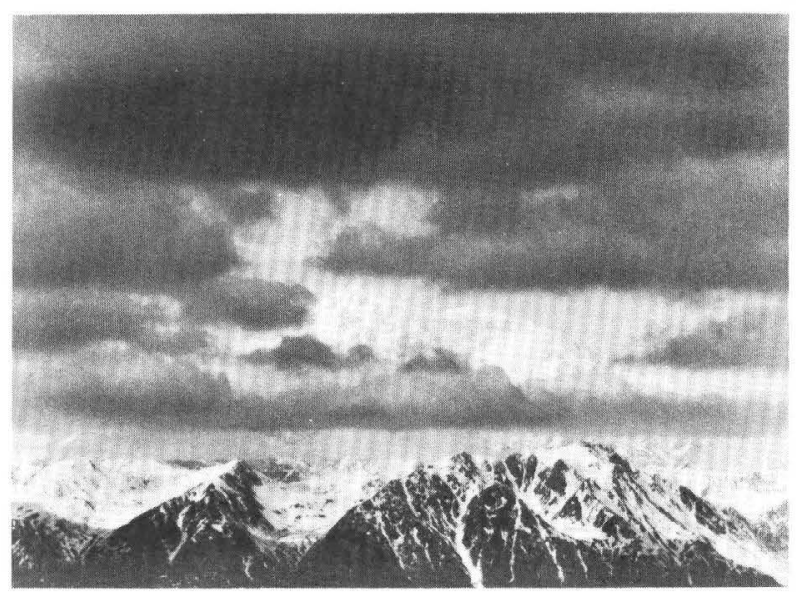

Mount McKinley as seen through the clouds from north of Talkeetna (1982). 


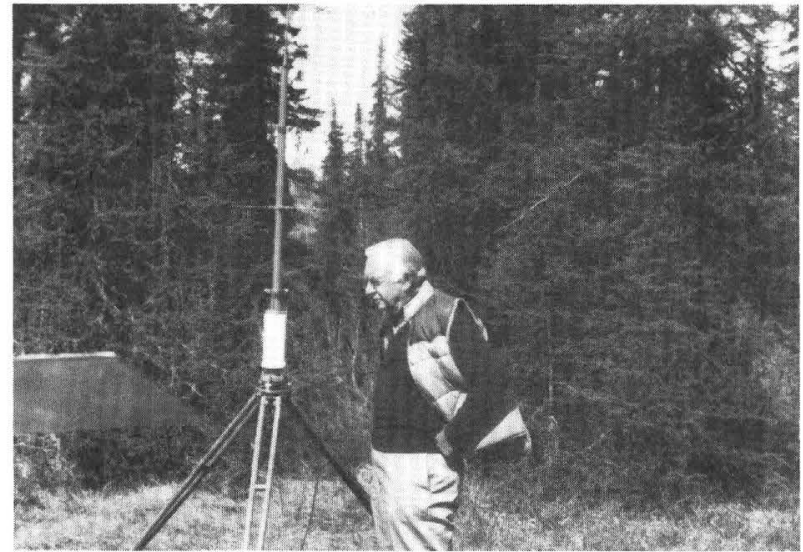

Walter Cronkite inspecting equipment during filming of Survey operations for "Universe" TV series (1982).

control network for the Defense Mapping Agency and for orthophotocontrol needs.

The three men assigned to the southeastern Alaska projects flew from Denver to Juneau on May 31. Their equipment was shipped by air from Denver a few days later after the crew had obtained vehicles from the General Services Administration and office space from the Water Resources Division. The two engineers and a field assistant assigned to the interior and western Alaska control projects also arrived in Anchorage on May 31.

The satellite tracking surveys proceeded at a rapid pace and were accomplished with only one major setback. The crew did not realize that permission was required from the operator of the Alaskan Pipeline and its Chief of Security in Fairbanks before working along the pipeline corridor. Two of the satellite tracking receiver instruments subsequently were confiscated by Alyeska security personnel. One unit had been placed directly beneath the pipeline at a point where the line is above ground, and the other unit had been placed on top of where the pipeline was buried. Security patrols, upon finding the receivers, assumed that they were radio-controlled bombs designed to sabotage the pipeline. While they were dismantling one of the units, an internal error alarm began to beep, and the security people scattered into the brush. About that same time, the Survey crew came back to check on the units. The security patrol was very understanding and cooperative while the field crew tried to talk their way out of the predicament, but the Security Chief in Fairbanks directed the patrol to confiscate the receivers. The units were placed in a refrigerator at pipeline Pump Station Seven. Subsequent discussions between the crew and Chief of Security in Fairbanks proved fruitless, even when the crew tried to impress upon the Chief the cost to the taxpayer of not being able to continue their surveying operations.

Finally, all was resolved, and the necessary permission was obtained. The units were returned with no loss of data, thanks to the cooperation of the security patrol, and were placed immediately in service.

Another aspect of the control work was to tie a 1975 National Geodetic Survey first-order level line, run along the pipeline road from Fairbanks to Prudhoe Bay, to a 600-mile verti-

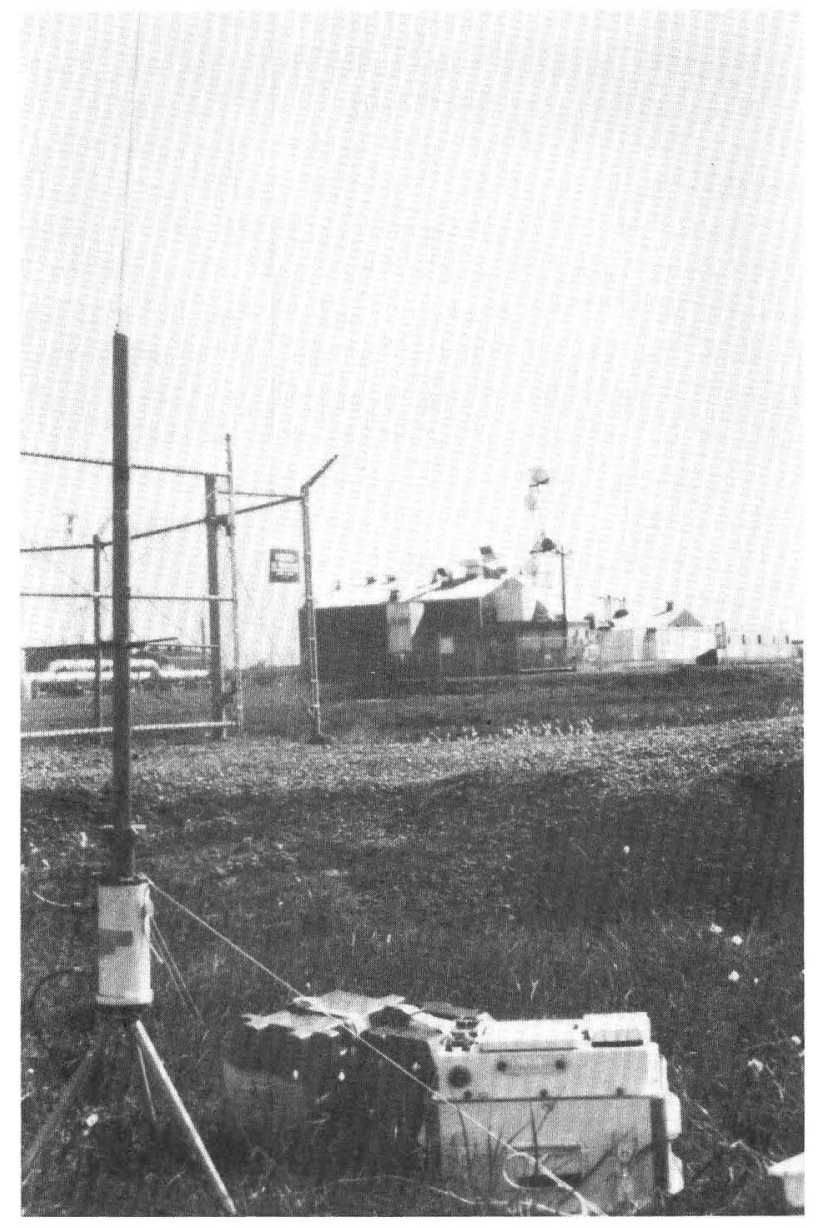

Satellite tracking receiver set up near pumping station as part of 1983 control tie work along the Alaskan Pipeline. 


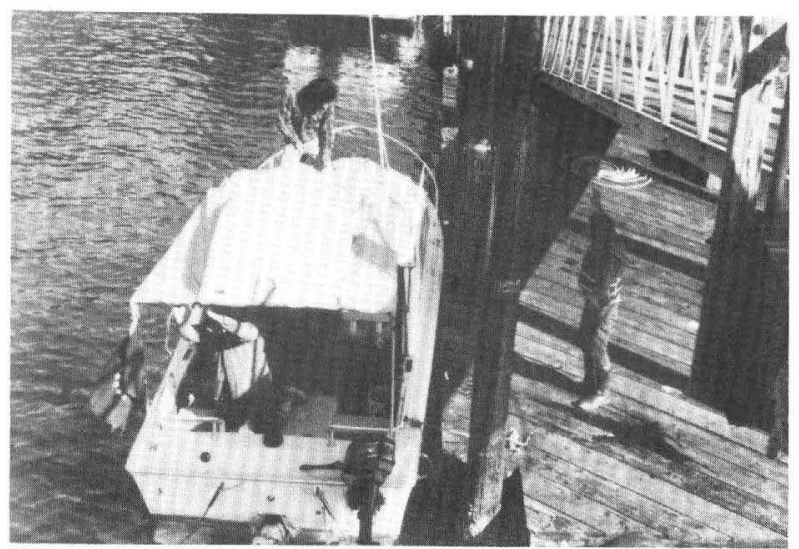

Readying the Tiloma for a day's work near Juneau. The small dingy was used to go ashore to identify existing control (1983).

cal angle traverse established during the 1970, 1971, and 1972 field seasons in the same general area. Six ties were established from the level line to the traverse between Fairbanks and the North Slope. Based on this new data, a readjustment of about 190 vertical angle elevations on primary horizontal stations is underway. A total of 77 point positions were occupied-21 for the geodetic control ties, 9 on bench marks along the Alaskan Pipeline, 31 to satisfy Defense Mapping Agency requests, and 16 for the Survey orthophoto program.

On completion of all control survey operations, one engineer returned to Denver, the field assistant was paid off, and the other engineer was assigned to the mapping projects in southeastern Alaska, where record-setting rains were delaying progress.

During August, a record 19 days of continuous rain hampered helicopter operations. Finally, skies cleared the last 2 days of August and the first week of September so that the map control could be completed on the Juneau and Sitka projects. Vehicles were returned to the General Services Administration, and the crew arrived back in Denver the second week of September.

\section{Summary}

In attempting to recount Alaska field operations, we have referred to where and when we were working and to what was or was not accomplished. We have included some of the problems encountered and have tried to recall various incidents of either a humorous or serious nature to provide an idea of what field life in Alaska was all about. Unfortunately, for those unfamiliar with Alaska or with working in virtually uninhabited country, it is almost impossible to appreciate the significance of what was accomplished or the hardships encountered.

References to localities may gloss over the fact that they were actually several hundreds of miles apart and may ignore totally the adverse conditions that might be encountered en route. Few can envision a couple of men landing on an isolated lakeshore with several tons of supplies to prepare a camp to house a crew of 1015 men who would arrive in 10 days. To say that the crew arrived on site on a certain date and returned to civilization so many days later infers accomplishment of the task during the intervening time. Yet, specific references may or may not have been made to the fact that the crew were holed up in their tents for days because of adverse weather or equipment failure without the benefit of modern conveniences.

Field operations in Alaska have been challenging but highly successful. All of Alaska except the Aleutian Islands now has 1:250,000scale topographic coverage to replace the older reconnaissance series. As the 1:63,360-scale ( 1 inch = 1 mile) series is completed, the quadrangles are combined to make new or revised 1:250,000-scale topographic quadrangles. When completed, it will take approximately 2,900 1:63,360-scale quadrangles to cover the entire State of Alaska, including the Aleutian Islands and the islands in the Bering Sea.

During the period from 1950 to 1955 , the U.S. Army 30th Engineering Battalion sent survey crews to Alaska to establish aerial photocontrol for their 1:50,000-scale mapping needs, principally in the areas of Prince William Sound, Kenai Peninsula, Alaska Peninsula, western Alaska, and the Arctic Coast. The 30th Engineers controlled and classified 1,109 mile-tothe-inch quadrangles and compiled 869 of these quadrangles. The Geological Survey compiled the remaining 240 quadrangles and made civil editions of all 1,109 quadrangles for publication. The Survey assigned liaison personnel to the 30th Engineers during summers 1953 
and 1954 to ensure work compatibility between the two organizations.

Additionally, the Geological Survey controlled, compiled, and published about 1,300 other 1:63,360-scale topographic quadrangles, for a total coverage at this scale of approximating 88 percent of the State. Maps covering an additional 8 percent of the State, mostly in areas of the Brooks Range and Bering Glacier, are in various stages of production. Only the Aleutian Islands west of Unalaska and isolated islands in the Bering Sea lack 1:63,360-scale coverage. Mile-to-the-inch mapping should be adequate for 99 percent of Alaska's mapping needs for many years to come.

At the present time, mapping authorizations are for 1:25,000-scale metric maps of the more settled areas and for orthophotoquads. The metric mapping projects are generally small areas around towns and do not require field camps or extensive helicopter or airplane operations.

In recent years, considerable effort has been made in preparing orthophotoquads for the $\mathrm{Bu}$ reau of Land Management and the State of Alaska from National Aeronautics and Space Administration high-altitude photography, in support of the Bureau's production of land plats of the public land surveys and the State's land disposal programs. Existing geodetic control and control photoidentification have minimized the requirement for additional Geological Survey fieldwork.

Considering the remoteness of the project areas, the unpredictabilty of the weather, and the dangerous situations encountered, the Survey's safety record has been remarkable. While we recognize, with regret, that the Geological Survey has lost a number of people, the Rocky Mountain Mapping Center has not lost anyone engaged in Alaska topographic mapping. However, the dangers were ever present.

Most everyone who went to Alaska was a volunteer. Some were better qualified than others either by experience or natural ability. During the first few seasons, when the crews were inexperienced, entire crews were composed of people who had never been to Alaska or who had never worked under camp conditions. After the first three or four seasons, however, operations became more efficient as people gained experience. Geological Survey Alaska project campsites are listed in Appendix A, and Alaska field crews are listed in Appendix B by year as well as the different camps, villages, roadhouses, or town locations.

Survey personnel were probably the least experienced in operating the boats than in any other phase of Alaska operations. The weather conditions in southeastern Alaska are very unpredictable. The crews did not have access to weather reports and had to interpret weather conditions for themselves. They not only had to interpret weather conditions, but also had to learn to read navigation charts and tide tables. Looking back on some of the situations the boat crews got into, it is truly remarkable that no one was lost, especially in the unprotected waters.

Not only were the Survey personnel inexperienced, but many of the earlier helicopter pilots had less than 200 hours flying time, no experience in Alaska, and probably very little mountain experience because of altitude limitations inherent in the earliest helicopters. As pilots with more flying time became available, even some with several seasons' experience in Alaska, and with dramatic improvements in helicopter performance since 1956, helicopter support improved considerably. Approximately 11,500 flying hours of helicopter support have been logged since 1948 . Fifteen accidents occurred in which the helicopters were a total loss; most of the helicopters were salvaged or rebuilt. During this period, no one died, and no one was injured seriously.

Fixed-wing aircraft have been used to some extent every year. Large cargo planes have been chartered for hauling fuel and camp equipment. It is difficult to estimate the number of hours that have been flown in fixed-wing aircraft, but the number probably exceeds 5,000 hours, and with an accident-free record. Float planes and wheel planes have been used, depending on the need, and amphibians have been used where situations called for water and ground landings. The safety record using airplanes has been remarkable, considering that many landings and takeoffs were on small lakes, river sandbars, frozen lakes, glaciers, and unimproved dirt strips and in all kinds of weather. Many landings were made on lakes and sandbars that had never been landed on before. The pilot had to have good judgment as 
to the length of the lake or sandbar and whether his plane had the capabilities of takeoff, once he landed. Most of these types of landings were made to cache fuel for helicopter operations.

Hopefully, the Survey's safety record in Alaska field operations will continue, for in no small way this remarkable safety record attests to the overall caliber and dedication of those who have served in Alaska in the past and will serve in the field seasons to come.

\section{Selected References}

*Brooks, A. H., 1906, The geography and geology of Alaska: U.S. Geological Survey Professional Paper 45, p. 104-132.

*FitzGerald, Gerald, 1951, Surveying and mapping in Alaska: U.S. Geological Survey Circular 101, 24 p. Reed, K. M. (ed.), 1982, The U.S. Geological Survey in Alaska-1982 programs: U.S. Geological Survey Circular 867, p. 11-17.

-Reproduced as Appendixes D and E, respectively. 


\section{APPENDIXES}




\section{Appendix A}

Alaska Project Campsites

[Location Map in Pocket]

1. Ketchikan-1949, 1955

2. Craig-1948, 1949, 1951

3. Bell Island-1955

4. Wrangell-1947, 1951

5. Petersburg-1951

6. Baranof Hot Springs-1951

7. Tenakee Springs-1949, 1951

8. Taku Harbor-1951

9. Juneau-1948, 1960, 1983

10. Chichagof Island-1947, 1948

11. Glacier Bay-1949

12. Mount Fairweather-1961

13. Comet-1948

14. Skagway-1949

15. Wells-1954

16. Yakatat-1959

17. Yakataga-1948, 1959

18. Katalla-1951

19. Cordova-1951, 1977

20. Seward-1979

21. Homer-1948, 1981

22. Kodiak-1948

23. Port Heiden-1963

24. Cold Bay-1963

25. Amchitka-1965, 1969

26. Kenai-1980

27. Alyeska-1979

28. Anchorage-1960, 1962, 1973

29. Palmer-1950

30. Chickaloon-1948

31. Sheep Mountain-1948, 1960

32. Valdez-1951, 1977

33. Chitina-1951

34. McCarthy-1959

35. Chisana-1959

36. Slana-1949

37. Chistochina-1960
38. Gulkana-1949

39. Talkeetna-1950, 1982

40. Skwentna-1954, 1958, 1978

41. Lake Clark-1958, 1979

42. Sparrevohn-1979

43. Farewell-1958, 1979

44. Lake Minchumina-1953

45. Wonder Lake-1954

46. Cantwell-Broad Pass-1947, 1950

47. Paxson-1950

48. Northway-1960

49. Gardiner Creek-1955

50. Tok Junction-1948, 1959

51. Dot Lake-1952, 1955

52. Black Rapids-1950

53. Ferry-1948, 1950

54. Big Delta-1948, 1950

55. Tanana-1953, 1956

56. Manly Hot Springs-1953

57. Standard-1950

58. Fairbanks-1950, 1966

59. Shaw Creek-1950

60. Chicken-1956

61. Woodchopper-1952

62. Central-1952, 1955

63. Sourdough Roadhouse-1952

64. Livengood-1952

65. Bettles-1956, 1970

66. Hughes-1956

67. Dahl Creek-1956, 1976, 1979

68. Wiseman-1971

69. Chandalar Lake-1956, 1971

70. Fort Yukon-1956, 1979

71. Circle-1956, 1980

72. Black River-1956

73. Arctic Village-1956, 1972

74. Galbraith Lake-1956

75. Elusive Lake-1971

76. Killik River-1956

77. Itkillik River-1971

78. Umiat-1956

79. Prudhoe Bay-1970

80. Sitka-1983 


\section{Appendix B}

\section{Alaska Field Crews \\ [By Year and Location]}

\section{7}

Joel Langhofer-Homer

John Zydik-Healy-Cantwell

Harold Werner-Heceta Island

Morrison Rousseau-Chichagof Island

Robert Lake-Chichagof Island

John Lyles-Wrangell, Stikine River

William Matheny-Liaison with Air Force, Fairbanks

\section{8}

Joel Langhofer-Yakataga

Lester Ganahl-Yakataga

Irving Gessley-Homer

Samuel Cleaver-Homer

Garland Wilcoxen-Homer

Morrison Rousseau-Chichagof Island

Robert Foley-Chichagof Island

William Matheny-Chichagof Island

Roy Wendolin-Chichagof Island

Richard Westfall-Chichagof Island

Cornelius Reisdorf-Chichagof Island

John Lyles-Comet

Harold Werner-Craig

Reynold Isto-Sheep Mountain-Chickaloon

Woodrow Knox-Sheep Mountain-Chickaloon

Jack Austin-Sheep Mountain-Chickaloon

Ernest Miller-Sheep Mountain-Chickaloon

John Zydik-Cathedral Bluffs

Frank Cernich-Cathedral Bluffs

Leo Hendrickson-Big Delta

Fred Heintz-Big Delta

James Jackson-Big Delta

Arturo Martini-Big Delta

Richard Larson-Ferry

1949

Reynold Isto-Central Alaska

E. Burton Benson-Gulkana

Leo Hendrickson-Gulkana

Robert Bartheld-Gulkana

Jesse Dyer-Gulkana

John Zydik-Tok Junction

Jerry Turner-Tok Junction

Steven Bethea-Tok Junction

Peter Johnson-Tok Junction

Joel Langhofer-Southeast Alaska

Harry McDermith-Ketchikan

Lester Ganahl-Ketchikan

James Dyer-Ketchikan
James Neff-Ketchikan

Harold Werner-Craig

Roy Wendolin-Craig

Morrison Rousseau-Glacier Bay-Skagway

Joseph Anderson-Glacier Bay-Skagway

Arthur Gervais-Glacier Bay-Skagway

Robert Foley-Glacier Bay-Skagway

Kenneth McLean-Glacier Bay-Skagway

John Lyles-Lynn Canal-Tenakee Springs

Fred Heintz-Kodiak

1950

Joel Langhofer-Railroad corridor

George Forney-Palmer-Rainbow Lake

William Gallogly-Palmer-Rainbow Lake

Joseph Anderson-Palmer-Rainbow Lake

Louis Plansoen-Palmer-Rainbow Lake

Floyd Bishop-Palmer-Rainbow Lake

Arthur Gervais-Standard-Ferry-McKinley Park

Robert Foley-Standard-Ferry-McKinley Park

James Jackson-Standard-Ferry-McKinley Park

Alvin Williams-Standard-Ferry-McKinley Park

E. Burton Benson-Highway corridor-30th Engineers

Louis Stevenson-Paxson-Black Rapids-Broad Pass

Robert Bartheld-Paxson-Black Rapids-Broad Pass

James Dyer-Paxson-Black Rapids-Broad Pass

Jesse Dyer-Paxson-Black Rapids-Broad Pass

Leo Hendrickson-Shaw Creek

Kenneth McLean-Shaw Creek

Grover Heinrichs-Shaw Creek

1951

E. Burton Benson-Central Alaska-30th Engineers

Leo Hendrickson-Cordova-Katalla

Jesse Dyer-Cordova-Katalla

Alfred Terrazas-Cordova-Katalla

Ned Druckenbrod-Cordova-Katalla

Melvin Harmel-Tonsina-Chitina

Irvin Benes-Tonsina-Chitina

James Dyer-Tonsina-Chitina

David Stubbe-Tonsina-Chitina

George Forney-Lake Louise

Peter Johnson-Lake Louise Jack Wonderly-Lake Louise Joseph Strange-Lake Louise

Steven Bethea-Clarence Lake

James Lee-Clarence Lake

Waymon Choate-Clarence Lake

Harold Werner-Clarence Lake

Reynold Isto-Southeast Alaska

Arthur Gervais-Tenakee Springs-Petersburg-WrangellKetchikan

Robert Bartheld-Tenakee Springs-PetersburgWrangell-Ketchikan 
Richard Longworth-Tenakee Springs-PetersburgWrangell-Ketchikan

Robert Foley-on a boat in southeastern Alaska

Louis Plansoen-on a boat in southeastern Alaska

Garland Wilcoxen-on a boat in southeastern Alaska

Kenneth McLean-Baranof Hot Springs

John Clemens-Baranof Hot Springs

Joseph Anderson-Baranof Hot Springs

John Lyles-Taku-Entrance Island

Samuel Cleaver-Taku-Entrance Island

James Jackson-Taku-Entrance Island

1952

Reynold Isto-Resident Engineer-Fairbanks

Leo Hendrickson-Central-Woodchopper

Jesse Dyer-Central-Woodchopper

Charles O'Brien-Central-Woodchopper

Jack Laird-Central-Woodchopper

Joseph Strange-Central-Woodchopper

Melvin Harmel-Dot Lake-Sourdough Roadhouse

Andrew Kordziel-Dot Lake-Sourdough Roadhouse

Richard Longworth-Dot Lake-Sourdough Roadhouse

George Staeffler-Dot Lake-Sourdough Roadhouse

1953

Reynold Isto-Resident Engineer-Fairbanks

Leo Hendrickson-Manly Hot Springs-Lake Minchumina

Melvin Harmel-Manly Hot Springs-Lake Minchumina

Irvin Benes-Manly Hot Springs-Fort Yukon

Joseph Anderson-Manly Hot Springs-Lake Minchumina

Richard Longworth-Manly Hot Springs-Lake Minchumina

Andrew Kordziel-Manly Hot Springs-Lake Minchumina

Louis Roberts-Manly Hot Springs-Lake Minchumina

Elias McClelland-Manly Hot Springs-Lake Minchumina

Thomas Taylor-Manly Hot Springs-Lake Minchumina

Isaac Johnson-Manly Hot Springs-Lake Minchumina

E. Burton Benson-30th Engineers

1954

Reynold Isto-Resident Engineer-Fairbanks

Alvin Williams-Wells-Wonder Lake

Thomas Williams-Wells-Wonder Lake

Thomas O'Brien-Wells-Wonder Lake

Robert Foley-Skwentna

Thomas Taylor-Skwentna-Wells

Joseph Anderson-Skwentna-Wells

Richard Longworth-Skwentna-Wells

E. Burton Benson-30th Engineers

Arthur Gervais-30th Engineers

Melvin Harmel-30th Engineers

\section{5}

Reynold Isto-Resident Engineer-Fairbanks

Robert Foley-Ketchikan-Gardiner Creek-Central

Thomas Taylor-Ketchikan-Gardiner Creek-Central

Louis Roberts-Ketchikan-Gardiner Creek-Central

Leo Hendrickson-Bell Island-Dot Lake
George Staeffler-Bell Island-Dot Lake

Thomas Williams-Bell Island-Dot Lake

Thomas O'Brien-Bell Island-Gardiner Creek-Central

E. Burton Benson-30th Engineers

Arthur Gervais-30th Engineers

1956

Reynold Isto-Resident Engineer-Fairbanks

Art Gervais-Western Brooks Range-Tanana

Donald Orth-Western Brooks Range-Tanana

Dean Newkirk-Western Brooks Range-Tanana

Joseph Anderson-Western Brooks Range-Tanana

Thomas Williams-Western Brooks Range-Tanana

Thomas O'Brien-Central Brooks Range-Chicken Donald Cochran-Central Brooks Range-Chicken Charles Ewing-Central Brooks Range-Chicken George Staeffler-Central Brooks Range-Chicken

Robert Foley-Eastern Brooks Range-Black River-Circle Louis Roberts-Eastern Brooks Range-Black River-Circle Edwin Murray-Eastern Brooks Range-Black RiverCircle

Robert Spirk-Eastern Brooks Range-Black River-Circle Thomas Taylor-Roving between camps-Name and classification

1957

Reynold Isto-Resident Engineer-Fairbanks No projects

1958

Reynold Isto-Resident Engineer-Fairbanks Robert Foley-Skwentna-Lake Clark-Farewell Andrew Kordziel-Skwentna-Lake Clark-Farewell George Staeffler-Skwentna-Lake Clark-Farewell Thomas Taylor-Skwentna-Lake Clark-Farewell Joel Swanson-Skwentna-Lake Clark-Farewell

1959

Reynold Isto-Resident Engineer-Fairbanks Arthur Gervais-Yakatat-McCarthy-Chisana Paul Antill-Yakatat-McCarthy-Chisana Kenneth McLean-Yakatat-McCarthy-Chisana George Staeffler-Yakatat-McCarthy-Chisana Thomas Taylor-Yakatat-McCarthy-Chisana

1960

Reynold Isto-Resident Engineer-Fairbanks

Robert Foley-Anchorage

Thomas Taylor-Northway-Chistochina-Sheep Mountain-Juneau

Kenneth McLean-Northway-Chistochina-Sheep Mountain-Juneau

Doyle Smith-Northway-Chistochina-Sheep MountainJuneau

Edwin Eckels-Northway-Chistochina-Sheep MountainJuneau

1961

Reynold Isto and Arthur Gervais-Resident EngineersFairbanks 
Elias McClelland-Mount Fairweather

Kenneth McLean-Mount Fairweather

Doyle Smith-Mount Fairweather

Joel Swanson-Mount Fairweather

1962

Arthur Gervais-Resident Engineer-Fairbanks

Kenneth McLean-Anchorage

William Runnels-Anchorage

Joel Swanson-Anchorage

Elias McClelland-Anchorage

1963

Arthur Gervais-Resident Engineer-Fairbanks Louis Roberts-Alaska Peninsula

Fred Weed-Alaska Peninsula

Jack Harry-Alaska Peninsula

1964

Arthur Gervais-Resident Engineer-Fairbanks

No mapping projects

Robert Foley-Anchorage earthquake studies

Alfred Dodd-Anchorage earthquake studies

Jack Helm-Anchorage earthquake studies

1965

Arthur Gervais-Resident Engineer-Fairbanks

No mapping projects

Robert Foley-Amchitka Island (Geologic Division)

1966

Arthur Gervais-Resident Engineer-Fairbanks

Kenneth McLean-Fairbanks

Donald Adkins-Fairbanks

Emery Miller-Fairbanks

1967

Arthur Gervais-Resident Engineer-Fairbanks

No mapping projects

1968

Arthur Gervais-Resident Engineer-Fairbanks

No mapping projects

1969

Thomas O'Brien-Resident Engineer-Anchorage

No mapping projects

Robert Foley-Amchitka Island (Geologic Division)

Courtney Swanson-Amchitka Island (Geologic Division)

Lloyd Bentley-Amchitka Island (Geologic Division)

1970

Thomas O'Brien-Resident Engineer-Anchorage

Arthur Gervais-Bettles-Prudhoe Bay

Robert Foley-Bettles-Prudhoe Bay

Gary Palmer-Bettles-Prudhoe Bay

Robert Spirk-Bettles-Prudhoe Bay

Douglas Hardwick-Bettles-Prudhoe Bay

1971

Thomas O'Brien-Resident Engineer-Anchorage

Robert Foley-Chandalar Lake-Elusive Lake
Charles Lough-Chadalar Lake-Elusive Lake

James Petzold-Chandalar Lake-Elusive Lake

James Pratt-Chandalar Lake-Elusive Lake

Courtney Swanson-Wiseman-Itkillik River

Ronald Wolbach-Wiseman-Itkillik River

Gary Palmer-Wiseman-Itkillik River

John Wadleigh-Wiseman-Itkillik River

Jack Harry-Wiseman-Itkillik River

1972

Thomas O'Brien-Resident Engineer-Anchorage

Courtney Swanson-Arctic Village

Kenneth Palmer-Arctic Village

Frank Aschert-Arctic Village

Richard Roth-Arctic Village

Leroy Sanford-Arctic Village

1973

Thomas O'Brien-Resident Engineer-Anchorage

Robert Foley-Anchorage

Courtney Swanson-Anchorage

Daniel West-Anchorage

Lyle Kemper-Anchorage

Larry Simmons-Anchorage

David McNutt-Anchorage

1974

Thomas O'Brien-Resident Engineer-Anchorage No mapping projects

1975

Thomas O'Brien and Thomas Taylor-Resident EngineersAnchorage

No mapping projects

1976

Thomas Taylor-Resident Engineer-Anchorage

Courtney Swanson-Dahl Creek (Bureau of Land Management Repay)

Robert Searcy-Dahl Creek (Bureau of Land Management Repay)

Leroy Sanford-Dahl Creek (Bureau of Land Management Repay)

1977

Thomas Taylor-Resident Engineer-Anchorage

Steven Crosby-Cordova-Valdez

Leroy Sanford-Cordova-Valdez

1978

Thomas Taylor-Resident Engineer-Anchorage

Courtney Swanson-Skwentna (Bureau of Land Management Repay)

Andrew Hinely - Skwentna (Bureau of Land Management Repay)

Leroy Sanford-Skwentna (Bureau of Land Management Repay)

Jon Sorenson-Skwentna (Bureau of Land Management Repay) 
1979

Thomas Taylor-Resident Engineer-Anchorage Wayne Gatson-Fort Yukon-Dahl Creek-Whittier Andrew Hinely-Fort Yukon-Dahl Creek-Whittier Daniel Hall-Fort Yukon-Dahl Creek-Whittier Robert Foley-Fort Yukon-Dahl Creek-Whittier

Courtney Swanson-Farewell-Sparrevohn-Lake Clark (Bureau of Land Management Repay)-Seward

Donald Lesovsky-Farewell-Sparrevohn-Lake Clark (Bureau of Land Management Repay)-Seward

Steven Crosby-Farewell-Sparrevohn-Lake Clark (Bureau of Land Management Repay)Seward

1980

Thomas Taylor-Resident Engineer-Anchorage

Wayne Gatson-North Kenai-Circle (Bureau of Land Management Repay)

Steven Crosby-North Kenai-Circle (Bureau of Land Management Repay)

David Lough-North Kenai-Circle (Bureau of Land Management Repay)

Carl Schoch-North Kenai-Circle (Bureau of Land Management Repay)
Leroy Sanford-North Kenai-Circle (Bureau of Land Management Repay)

Robert Foley-North Kenai-Circle (Bureau of Land Management Repay)

1981

Thomas Taylor-Resident Engineer-Anchorage Courtney Swanson-Homer

David Lough-Homer

Abe Trimble-Homer

Jeffrey Roche-Homer

1982

Thomas Taylor-Resident Engineer-Anchorage Abe Trimble-Talkeetna

Jeffrey Roche-Talkeetna

Courtney Swanson-Talkeetna

1983

Thomas Taylor-Resident Engineer-Anchorage Abe Trimble-Control

David Lough-Control

Courtney Swanson-Juneau-Sitka

Jeffrey Roche-Juneau-Sitka

Phillip Ibarra-Juneau-Sitka 


\section{Appendix C}

\section{Alaska Geographic Features Named For}

U.S. Geological Survey Employees

[Compiled by R. M. Chapman, 1982]

Cleveland Abbe, Jr.

J. W. Bagley

Marcus Baker

E. C. Barnard

C. T. Bressler

A. H. Brooks

S. R. Capps

Theodore Chapin

W. H. Dall

H. M. Eakin

G. H. Eldridge

R. E. Fellows

Bernard Fisher

Gerald FitzGerald

G. M. Flint, Jr.

T. G. Gerdine

C. E. Giffin

R. U. Goode

E. C. Guerin

C. W. Hayes

R. E. Isto

R. W. Juhle

Adolph Knopf

E. de K. Leffingwell

R. S. MacColl
Mount Abbe in Glacier Bay National Monument.

Bagley Icefield in St. Elias Mountains area.

Baker Glacier in Chugach Mountains; Baker Island in southeastern Alaska; Baker Point in Kasaan Bay; Mount Marcus Baker and Marcus Baker Glacier in Chugach Mountains.

Mount Barnard in Glacier Bay; Barnard Glacier in St. Elias Mountains. Note: Barnard Glacier in College Fiord is named for Barnard College.

Mount Bressler in Juneau Icefield.

Brooks Range in northern Alaska; Mount Brooks and Brooks Glacier in Alaska Range; Brooks Mountain on Seward Peninsula; Brooks Lake and Brooks Falls in Katmai National Monument; Brooks also was used as a temporary early name for the village of Livengood.

Capps Glacier near Tyonek; Mount Capps in Alaska Range.

Chapin Peak on Gravina Island, southeastern Alaska.

Mount Dall in Alaska Range; Dall Island in Dixon Entrance; Dall Point near Hooper Bay; Dall Ridge on Gravina Island; Dall River tributary to Yukon River.

Mount Henry Eakin in Ray Mountains, Tanana quadrangle.

Mount Eldridge and Eldridge Glacier in Alaska Range.

Mount Fellows in McKinley Park area.

Fisher Caldera on Unimak Island.

Fitz Creek at Chinitna Bay, Alaska Peninsula.

Flints Point near Iyoukeen Cove, southeastern Alaska.

Mount Gerdine in Tordrillo Mountains, near Tyonek.

Giffin Glacier in St. Elias Mountains.

Mount Goode near head of Knik Glacier, Chugach Mountains.

Guerin Lake on Admiralty Island. Probably named for this topographer.

Mount Hayes in Alaska Range; Hayes Glacier in Tordrillo Mountains.

Mount Isto in eastern Brooks Range.

Mount Juhle in Katmai National Monument.

Mount Adolph Knopf near Giley Glacier and Juneau Icefield, southeastern Alaska.

Leffingwell Glacier and Creek in eastern Brooks Range. (He was not an employee, but his work was published by the Geological Survey.)

MacColl Ridge in St. Elias Mountains. 
G. C. Martin

J. B. Mertie, Jr.

D. J. Miller

F. H. Moffit

Robert Muldrow

W. J. Peters

W. S. Post

L. M. Prindle

H. F. Reid

I. C. Russell

R. H. Sargent

F. C. Schrader

V. E. Shainin

P. S. Smith

A. C. Spencer

J. E. Spurr

R. S. Tarr

Martin Webories

D. C. Witherspoon

W. E. Wrather

C. W. Wright

F. E. Wright
Mount Martin and Martin Creek on Alaska Peninsula. Numerous other features with Martin name are named for others.

Mount Mertie (or Mertie Mountains) in Eagle D-6 quadrangle near Charley River. Proposed in 1981 ; is not yet approved.

Don Miller Hills near Katalla.

Mount Moffit in Alaska Range.

Muldrow Glacier on Mount McKinley.

Peters Lake in Brooks Range; Peters Glacier at head of Muddy River in Alaska Range.

Post River in Kuskokwim River area.

Mount Prindle in White Mountains; Prindle Volcano in Fortymile area.

Reid Glacier and Reid Inlet in Glacer Bay area. (He was an advisor on glaciology and earthquakes to the Geological Survey, 1901-1914.)

Mount Russell in Alaska Range; Russell Fiord and Russell Island in St. Elias Mountains area; Russell Glacier in Wrangell Mountains.

Sargent Icefield on Kenai Peninsula.

Schrader Lake in Brooks Range; Schrader Bluff on Anaktuvuk River; Schrader Creek near Chandalar Lake; Mount Schrader near Valdez.

Shainin Lake in Brooks Range.

Philip Smith Mountains in Brooks Range.

Spencer Peak near Mendenhall Glacier and Juneau Icefield. Several more features with Spencer name are named for others.

Mount Spurr near Tyonek.

Tarr Inlet in Glacier Bay National Monument. Tarr was chiefly with National Geographic Society but was affiliated with the Geological Survey.

Webories Creek (Tanana B-6 quadrangle). Webories accompanied J. B. Mertie between Poorman and Ophir in 1933, was a camphand for Mertie in 1934, and worked for a short time as horse packer for Chapman in 1943.

Mount Witherspoon in Chugach Mountains near Valdez.

Mount Wrather near Mendenhall Glacier and Juneau Icefield, southeastern Alaska.

Mount Wright near Ketchikan, location uncertain and not shown on current maps. Probably named for these two geologists. 


\section{Appendix D}

\section{HISTORY OF EXPLORATIONS AND SURVEYS.}

\section{INTRODUCTION.}

The following sketch is based on a rather desultory examination of the literature at odd times during four or five years. While the value of the statements would have been much enhanced by the citation of authorities this was not possible in the time available for preparation.

The bibliography ${ }^{a}$ appended to this report contains the titles of all the works consulted, which are only a small part of the voluminous literature upon Alaska. It has been possible to make a more or less careful study of the important publications relating to the Territory since its acquisition by the United States, but many of those which deal with the earlier period, particularly the Russian, were not consulted, and the writer has had to rely in part on the three standard works on Alaska which contain important summaries of its history. These are: Alaska and Its Resources, by William H. Dall, 1870; Report on Population, Industries, and Resources of Alaska, by Ivan Petrof, Tenth Census, vol. 8, 188t, and History of Alaska, by Hubert Howe Bancroft, 1886.

\section{GEOGRAPHY AS RELATED TO DEVELOPMENT.}

The history of Alaska will be more easily understood if the avenues of approach for explorers and settlers are briefly discussed. Alaska's peninsular form and irregular shore line give a coast exposure of great extent (Pls. II and VII). Some of this fronts upon the frozen sea and adds little to the accessibility of the country, but much the larger part is washed by waters which are open to navigation throughout the year, and along this extensive seaboard the first explorations and settlements were made. An almost unbroken series of ranges--the Pacific Mountain system-lies near the Pacific shore line and offers a barrier which long prevented inland exploration or settlement; for only within recent years have passes through it been discovered. The broad, depressed interior area lying behind this ridge is again cut off from the coast region on the north and east by another mountain chain, here termed the Rocky Mountain system, which also retarded man's approach, because it interposed a barrier between the interior of Alaska and that extensive system of waterways of northern Canada which enabled the fur traders to find their way across the continent from the Atlantic seaboard. This Central Plateau region, as it has been called, opens out to Bering Sea, into which it pours most of its drainage through two great rivers, the Yukon and Kuskokwim, both of which are navigable and afford easy access to the interior.

Another important geographic feature of Alaska in relation to its development is its juxtaposition to Asia. The westernmost point of its mainland is visible from the Siberian coast across Bering Strait, only 60 miles wide; but as this strait is

a The publication entitled, "Partial List of Charts, Mraps, and Publications Relating to Alaska and Adjacent Regions, by W. H. Dall and Marcus Baker," Pacific Coast Pilot. Appendix 1, Meteorology and Bibliography, U. S. Coast and Geodetic Survey, Washington, 1879, has not yet been supplemented and remains to-day the only bibliography of works relating to Alasku. 
navigable only in summer, it is of less importance as a route of travel than the Aleutian Islands, which form a chain almost connecting the Asiatic and American continents. These islands are mostly intervisible, so that as soon as the western one had been reached from Asia even the Russian traders, who were usually entirely unskilled in navigation, could follow the archipelago eastward to the mainland.

\section{MAIN FEATURES OF HISTORY.}

A complete history of the discovery and exploration of Alaska would involve a consideration of the history of eastern Asia and western Canada, as well as of the explorations of the northern Pacific and the Arctic region, and is beyond the scope of the present paper. In the few pages here devoted to the subject it is possible only to broadly outline the progress of discovery, calling attention to a few of the more important expeditions which have added to the geographic knowledge of the country and the agencies which were operative in its exploration. During the two centuries which have elapsed since white men first obtained definite tidings of Alaska, exploration and surveys have been carried on spasmodically by various nationalities and under various auspices. Though the larger geographic features are now fairly well known, there still remain some unexplored areas, and the topographic mapping is hardly begun.

Explorations of the northwestern corner of America may be said to have been made from three directions-from the west by the Russians, across Siberia and Bering Sea; from the east by the English, through the Mackenzie Valley, and from the south by navigators of various nationalities exploring the eastern shore of the Pacific.

Before the end of the sixteenth century Russian fur traders crossed the Urals, gradually extended their operations eastward across northern Asia, and established themselves on the shores of Bering Sea. During this time the French voyageurs and their successors of English blood had been making their way westward from the Atlancic coast. Reaching the Rocky Mountain barrier they were there held in check for over a hundred years, but before the middle of the nineteenth century they had surmounted this obstacle and established trading posts on rivers tributary to the Pacific and the Bering Sea. Meanwhile the Russians crossed Bering Sea and had taken possession of Alaska. By the beginning of the nineteenth century the fur trade which had been developed by these two nationalities had left the hands of individuals and in both cases had come under the control of a strong company. The two rival fur-trading interests, which had been moving toward each other for upward of two centuries, after practically encircling the globe finally came into competition in Alaska. These facts are recited here because the desire to obtain control of and exploit the fur trade was directly or indirectly the prime motive for the early explorations of the territory.

\section{EARLY RUSSIAN EXPLORATIONS. $a$}

Less than a century after the discovery of the American Continent Yermac Timofeief and a band of Cossack adventurers crossed the low barrier of the Ural Mountains and began that series of conquests in Siberia which was to make Russia

$a$ For the authorities consulted in preparing this sketch see pp. 298-808. 
an Asiatic power. While the western nations of Europe were exploring the east coast of North America, and almost before they had obtained a foothold on its shores, the Russian Cossacks had crossed northern Siberia and in 1638 reached the sea of Okhotsk. Step by step these Cossack adventurers made their way across the great lowlands of northern Siberia, traveling with horses by land and skin boats by water. The comparatively peaceful character of the natives and the absence of mountain barriers greatly facilitated the work of conquest.

After reaching salt water it was but natural that the Cossacks should extend their explorations along the coast. In 1648 Deshnef sailed eastward from the mouth of the Kolyma on the Arctic, rounded East Cape, passed through the body of water afterwards named Bering Strait, and wintered at the Anadir River. More than half a century elapsed before this exploration was extended by another Cossack, Popof, who, in 1711, was sent to East Cape to induce the natives to pay tribute. The warlike Chuckchees, who inhabited that part of the Siberian coast, refused to acknowledge the sovereignty of Russia, but Popof brought back an account of the Diomede Islands in Bering Strait and rumors of a continent said to lie to the east.

In course of time news of this discovery was transmitted to St. Petersburg, and the reigning sovereign, Peter the Great, was quick to realize its importance. Spurred on, no doubt, by the knowledge he had of the discoveries and settlements made by the western nations of Europe in the New World, Peter ordered the organization of an expedition which should verify Popof's statements and extend his explorations. Vitus Bering, a Dane and fleet captain in the Russian nary, was placed in charge of the expedition. Peter did not live to see his plans executed, dying soon after signing Bering's orders; but his successor, the Empress Catharine, actively carried out the purpose of her husband. Bering's command, after crossing Siberia, built two small vessels at Okhotsk. In July, 1728, he sailed northward along the coast of Siberia as far as East Cape, passing through the strait which bears his name. From East Cape he stood to the northeast for a day and then returned to his port of embarkation without having sighted the American Continent.

While Bering himself . believed that his short voyage definitely proved the absence of an eastern connection of Asia with North America, yet so meager was his evidence that most geographer's refused to accept it, and it was not until Cook's royage, half a century later, that convincing proof was obtained. Bering did, however, discover and name St. Lawrence Island, and may therefore be regarded as the first white man to look upon any part of what is now Alaska.

Three years later a vessel in command of a Cossack named Gwosdef, one of a small fleet sent to subdue the Chuckchees, was blown onto the American coast by a storm, probably somewhere in Norton Sound. The records of this voyage, vague as they are, contain the first reference to the mainland of Alaska based upon the actual observations of white men. In the following year (1729) Bering made a second voyage, which was even less fruitful of results.

The interest excited by these discoveries led to the organization at St. Petersburg of another expedition, of which Bering was again put in command. Such were the difficulties of travel that six years were spent in transporting the party and outfit across Siberia, which at that time afforded nothing except game, fish, 
and furs, so that all supplies, including the ironwork and tools necessary for the construction of ships, had to be brought from Furope. Finally, in 1741, the expedition sailed from Okhotsk in two vessels, one commanded hy Bering himself and the other by Chirikof. These soon became separated, and Bering, sailing eastward, on July 18 fell in with the American coast near Mount St. Elias, which be named, and a few days later landed on what was probably Kayak Island.

With this discovery Bering seemed to consider that his mission was fulfilled, and after a very cursory examination became impatient to return to Asia. The expedition, which had taken years of preparation, turned westward without attempting surveys or investigations and without even making a landing on the mainland of the newly discovered continent. Sailing southwest they discorered the Shumagin Islands, and named them after a member of the crew who was buried there.

Bering's haste to return to Asia again prevented him from making an adequate exploration. He continued westward along the line of the Aleutian Islands, some of which he sighted, but without gaining more than a very superficial knowledge of them. Scurvy broke out among the crew, and the entire party seems to have been bewildered. They sailed hither and yon, now heading for the American, now for the Asiatic coast, at last wrecking their vessel upon Bering Island of the Commander group, now belonging to Siberia. Of those that reached the shore many died, among them Bering, a disheartened and despairing man. The cross over his grave was the first emblem marking the extension of Russian sovereignty eastward of Siberia. The survivors of the illfated expedition built a small vessel of the wreckage and returned to Kamchatka.

Chirikof's voyage was even less successful. After becoming separated from Bering he sailed eastward, and on July 15 sighted the continent, probably near Cross Sound. An attempt to land ended disastrously, for both boats were lost, and nearly a third of the crew were killed by the natives. Chirikof hastily put to sea and returned to the Asiatic coast, sighting some of the Aleutian Islands in his passage.

The explorations made by these two navigators, while not fruitful of results commensurate with the elaborateness of the preparations, were yet of the utmost importance from a geographic standpoint. Two points on the American Continent were fixed with a fair degree of accuracy and the location of some of the Aleutian Islands approximately established. These islands, which are part of the broken chain connecting the Asiatic and North American continents, were to become an important factor in the early development of the fur trade of Alaska.

The reports by Bering's crew of the existence of valuable furs in the newly discovered islands cast of Kamchatka soon led the hardy Siberian fur hunters, called promyshleniki, to brave the perils of an unknown sea. The first of these was Bassof, who two yeurs after Bering's return reached Bering Island in a small vessel. The rich harvest of furs with which he returned after a year's absence induced him to make a second, and later a third voyage. He was but the forerunner of a swarm of promyshleniki who gradually pushed their way eastward along the Aleutian chain of islands to the mainland of Alaska. 
These Siberian fur hunters had up to this time but little knowledge of deep-sea navigation, an ignorance which fitted them in a measure for the task which they had undertaken, for experienced seamen would have refused to take part is such utterly hazardous and foolhardy enterprises. As all iron for shipbuilding on the Bering Sea had to be transported across Siberia to Kamchatka, the result was that a species of vessel was devised which could be constructed without iron, the planks being sewed together with thongs of rawhide in lieu of nailing. Provisions also were scarce in Kamchatka, and these roving traders depended largely on such food as could be obtained from the sea.

In these crude crafts, manned by crews which knew little of seamanship, and usually but ill-equipped and provisioned, these intrepid fur traders boldly pushed out into unknown stormy seas. Many lives were lost by wrecks, starvation, and scurvy, and many of the adventurers met deserved death at the hands of the outraged natives. The risks were great, but when the expeditions were successful the protits were enormous, and the necessary capital for such enterprises was easily procured among the merchants of eastern Siberia.

This vanguard of civilization was made up of men who had no virtues other than valor and intrepidity. Their gradual mastery of the Aleutian Islands, which led to Russia's becoming a North American power, is a tale of blood and rapine, of murder and outrage. Under plea of exacting tribute from the natives they took their furs by force and not by barter, practically reducing the natives to slavery. Their firearms gave them an incalculable advantage over these people, whose arrows and spears were still tipped with bone. The Aleuts, at first friendly to the strangers, only too soon learned their true character; and though not so warlike as the true Eskimos to the north, or the Haidas and Thlinkets of southeastern Alaska, with whom the Russians later came in conflict, did not give up without resistance. Many a bloody and well-deserved reprisal did they inflict on their oppressors. The struggle was, however, hopeless; ravages of the barbaric Siberian fur traders during the half century succeeding Bering's discoveries threatened to exterminate the indigenous population of the Aleutian Islands. While the outrages were largely the work of private individuals they received a certain sanction from the Russian Government, which allowed the traders to plunder and murder the natives at will, but was ready enough to exact tribute on the ill-gotten furs. The cry of the murdered and outraged Aleut did not reach St. Petersburg, or if it did was not heeded.

It was through this murderous crew of traders that the civilized world learned of the Aleutian Islands and the adjacent mainland. Russia was to owe her American colony to the initiation and enterprise of private individuals, for the Court of St. Petersburg paid little heed to its American possessions for more than half a century after Bering's last voyage. But two attempts at official investigation were made, both more or less abortive. In 1767 Lieutenant Synd, of the Russian Navy, was sent out to explore the American coast, and though his results were meager and his statements unreliable, there seems no reason to doubt that he landed on the southern coast of Seward Peninsula. About the same time Captain Krenitzin reached the Alaska Peninsula on a similar mission.

When the Spanish and English first appeared on this coast Russia had no permanent settlement in Alaska. Bering's expedition had discovered a new continent; 
yet though a third of a century had passed during which private enterprise had developed a lucrative fur trade in the adjacent islands, no effective attempt had been made to extend his discoveries or to exploit the resources of the main continent. The trading voyages had approximately established the relative location and configuration of the Aleutian Islands and Kodiak. Krenitzin had astronomically determined a few positions in the eastern part of the chain and along the southern coast of the Alaska Peninsula. These, together with Bering's discovery, and a less definite knowledge of the mainland lying adjacent to Bering Strait, comprised Russia's investigations in North America previous to the advent of other nations.

\section{EXPLORATION BY RIVAL NATIONALITIES.}

While the Russian influence was extending over Alaska from the west the Spaniards were approaching it from the south, where they had established themselves on the coast of California. Reports of these Russian encroachments led the viceroy of Mexico to send out several successive expedirions to explore the coast and where they found it uninhabited to plant the arms of Spain. Perez, a Spanish ensign, discovered the Queen Charlotte Islands in 1774, and the following year Lieutenant Quadra explored as far north as Cross Sound.

The first important systematic survey of any part of what is now known as Alaska was made by Captain Cook, the great English navigator. Cook sailed from England with two vessels in 1776. His first landfall on the Alaskan coast was in May, 1778, near Mount Edgecumbe, previously discovered by Bodega y Quadra. Thence he sailed westward, exploring Prince William Sound and Cook Inlet as far as Unalaska, where be was received very kindly by a band of Russian traders. It is of interest to note that an American in Cook's vessel, John Ledyard, was the first to interview the Russians.

Cook now entered Bering Sea and continued his surveys of the coast toward the north, through Bristol Bay, Norton Sound, and Bering Strait, until he was checked by the Arctic ice pack. This he skirted westward to where it impinged on the Siberian mainland at a point which he named Cape North, whence he returned to the south along the Siberian coast. The winter was spent in the Hawaiian Islands, and there the famous navigator met his death. The following year his vessels set out again under the command of Clerke, in an attempt to extend the surveys farther north, but the ice pack again interfered before they had penetrated much farther than before.

Cook had been unsuccessful in finding the water passage to Hudson Bay which he sought, but in the course of a single summer he had accomplished many times as much as all previous explorers. His voyage outlined the larger coastal features of Alaska, from about latitude $58^{\circ}$ to $70^{\circ}$; definitely established the fact that there was no land connection between America and Asia, and convinced the navigator himself of the futility of seeking a waterway to the Atlantic, a conclusion which was in part based on Hearne's exploration in 1771 from Hudson Bay to the mouth of the Coppermine River. This last result was not generally acknowledged, and it remained for one of Cook's officers, Vancouver, to bring the final proof-not even then accepted by the theoretical geographers-about fifteen years later.

$$
17211-\text { No. } 45-06-8
$$


Great as was Cook's contribution to the geography of the Alaskan coast, perhaps of still more lasting importance was his inauguration of a new era in the explorations of the Alaskan seaboard. The vague and haphazard reports of the previous explorers were replaced by concise charts and accurate observations, many of which have stood the test of more detailed investigation. Several officers who accompanied Cook and were trained in his methods returned in later years to the Alaskan coast and continued the work of exploration.

Though some of the promyshleniki had reached Kodiak as early as 1762 , it was not until after Cook's voyage that, finding the sea otters were becoming relatively scarce among the Aleutians and the voyages less profitable, they began to seek new hunting grounds to the northeast. Up to this time the fur gathering had been in the hands of individuals or small, weak companies, and hence but little concerted effort had been made. In 1781 a company of eastern Siberian merchants was formed for exploiting the American fur trade. The leader of this organization was Gregor Ivanovich Shelikof, who, with Ivan Golikof, controlled a majority of the shares. Under Shelikof's leadership an expedition was sent out, which, in 1783, founded a colony at Three Saints Bay, near the southern end of Kodiak Island. This was the first settlement within the limits of Alaska and was the pioneer of the Russian occupation, which was to last for three-quarters of a century, until the territory was transferred to the United States.

In the year this colony was founded a group of trading vessels, under the command of Potan Zaikof, reached Prince William Sound. He attempted the same high-handed proceedings which had been so successful among the Aleuts, but found to his cost that he was dealing with a fierce, warlike population, and the expedition ended disustrously. The event was noteworthy, as it was the first time the Russian traders are definitely known to have reached the mainland. Nagaief, a member of this party, discovered the Copper River and ascended it a short distance.

In the meantime the published account of Cook's voyage had aroused other nations to the fact that the rich fur trade in the northwestern extremity of the American continent was rapidly passing into the hands of the Russians. The English traders were the first to follow it up. In 1785 James Hanna visited the west coast of Vancouver Island, in British Columbia, and in the succeeding years made several voyages to the coast of what is now Alaska. Similar trips were made by English and American trading vessels and ships of other nationalities. The published logs and track charts of a number of these vessels added to the general knowledge of the northwest coast. All of these the Russians regarded as unlawful intruders, and many petitions were sent to St. Petershurg protesting against foreign ships engaging in this trade.

While merchants and traders of various nationalities were struggling for commercial supremacy in Alaskan waters, their home governments were not unmindful of the political side of the controversy. The English, Spanish, and French govern. ments showed a desire to wrest some of these new discoveries from the Russians. The Spaniards claimed the coast, because it was a northern extension of their California possessions, and also by right of the discoveries of Bodega y Quadra. The English claim rested on Cook's discoveries. 
The Spanish claims were strengthened by an expedition led by Arteaga, with Quadra as second in command, which sailed northward from Mexico in 1779, and visited and surveyed Port Bucareli on the west side of Prince of Wales Island. Later they entered Prince William Sound and, in obedience to their instructions, took formal possession of what they believed were newly discovered lands. They little realized that Cook in the previous year had gone through the same ceremony in the name of the British sovereign almost at the same spot. After extending their explorations to the southwest as far as the southern end of the Kenai Peninsula they returned to Mexico.

The French had no part in the discovery or in the exploitations of the new country; but to gain a valid claim, La Perouse, a naval officer, was dispatched to the northwest coast in 1785 . In the following year he landed at Lituya Bay, of which he made a detailed examination and took formal possession. Then, ignoring his instructions to survey the Aleutian Islands, he sailed southward without landing again on the Alaskan coast.

The Spaniards, apparently satisfied that Arteaga's explorations established their territorial claims, took no further action for several years. The publication of Cook's voyages and the report of the numerous trading vessels that visited the northwest coast, however, aroused them again from their lethargy. In 1788, two vessels, commanded by Estevan Martinez and Gonzalez Haro, were dispatched northward to gain further information. While Martinez explored Prince William Sound, Haro visited the Russian establishments on Kodiak Island, and obtained full knowledge of the Russian occupation. Delarof, the director of the colony, took pains to impress the Spaniard with the wide extent and importance of the Russian settlements, of which at that time there were only six. After visiting Unalaska and going through the absurd performance of taking possession in the name of His Most Catholic Majesty of an island which contained a Russian colony and had been under Muscovite influence for upward of a quarter of a century, the expedition sailed for Mexico.

Martinez's report of the Russian occupation showed the viceroy of Mexico that Spanish claims to the northwest coast must be enforced by more decisive action. Both vessels were therefore again dispatched to take immediate possession of Nootka Sound on the west side of Vancouver Island, which had been discovered by Cook and had been used as a rendezvous by English, American, and Portuguese traders. The Spaniards did not molest the American ships, but warned off all those flying English colors. This high-handed action led to an immediate protest by the British Government, and commissioners were appointed by both governments to come to an understanding. The first meeting at Nootka led to a disagreement; but subsequently the Spaniards receded from their position and withdrew their forces, leaving the region in the possession of the traders and natives.

In 1791 Malaspina, an Italian navigator, in command of two Spanish corvettes, engaged in a scientific exploration which was to encircle the globe. He was sent to the northwest coast to explore for a northwest passage, rumors of which were again gaining credence. He made landfall near Mount Edgecumbe, 
and tracing the coast to the northwest entered Yakutat Bay, then known as Port Mulgrave. The ceremony of taking possession of the newly discovered land was not omitted, though Portlock and Dixon had surveyed and published a chart of the bay some years before, and the Russians had long used it as a rendezvous in their fur-trading expeditions. Malaspina made a cursory examination of Prince William and Cross sounds, and then turned southward.

George Vancouver, one of Cook's midshipmen, was the English representative in the Nootka dispute, and while his conferences with the Spaniards had no jmmediate result, his later explorations were of the utmost importance. He received orders to survey the coast between the thirty-fifth and sixtieth parallels of latitude, a task which he faithfully executed with his two vessels in 1793 and 1794. In the course of two seasons he accurately delineated thousands of miles of the coast line of southeastern Alaska, and supplemented the work of previous explorers westward as far as Cook Inlet. Not an indentation of the mainland, hardly a break in the shore line of the numerous islands, escaped his notice. His would have been a difficult task even in the days of steam, and to thread the intricate waterways of the Alexander Archipelago and make such surveys as he did within so short a period was little short of marvelous. He was a worthy successor of the great Cook, under whom he had learned navigation and geodesy. After his task was completed the general features of the entire coast line of the mainland of Alaska from Dixon Entrance as far north as Cape Belcher were charted with a fair degree of accuracy.

While the Russians and the Spaniards were attempting to dispossess all other nations of commercial and territorial rights in the coastal zone of Alaska, the English, their most aggressive rivals, were steadily approaching the region from the east. The French pioneers, following the route of the Great Lakes, had crossed half of the American continent long before the Russians had knowledge of the Aleutian Islands, and about the time of Bering's discovery of the mainland of Alaska, Verandrye had reached the foothills of the Rockies near the headwaters of the Missouri. Ten years later another pioneer trader established a post at the present sight of Calgary (Alberta), at the very base of the Rocky Mountains and only 500 miles from the Pacific waters. This post, with many others, was abandoned when Canada passed into the hands of the English.

Henceforth the English fur trade gradually expanded into the region which had been pioneered by the French. The Rocky Mountain barrier for a long time marked the limits of this western fur trade. It remained for Alexander Mackenzie to surmount this barrier, and to introduce a new factor in the derelopment of Alaska. Mackenzie, who was a member of the Northwestern Fur Company, the great rival of the Hudson Bay Company, ascended the Peace River from Lake Athabasca, crossed the Rocky Mountains, then traversed the headwaters of the Fraser, and after crossing the Coast Range reached Pacific waters in the latitude of Queen Charlotte Sound. This journey, which was the first made across the continent north of Mexico, was accomplished in 1793, at the same time that Vancouver was surveying adjacent waters. It was the forerunner of the fierce rivalry which was to spring up between the two great competitors in the fur trade, the Russian-American and Hudson Bay companies. 
In spite of the small degree of success achieved by previous official explorations, the authorities at St. Petersburg in 1785 determined on anotier. This was placed in charge of Joseph Billings, who seems to have been chosen more because he had been attached to one of Cook's vessels than because of any particular merit or experience. Billings sailed from Kamchatka in 1789 , and passing through Bering Strait penetrated the Arctic Ocean to about latitude $69^{\circ}$ and then returned to Kamchatka. In 1790 he made a second start, and the two vessels of the expedition, stopping at Unalaska and Kodiak, reached Prince William Sound, and then again returned to the point of debarkation. In the following year a third start was made and Billings once more reached Unalaska, whence he sailed northward, touching at Pribilof Islands, Seward Peninsula, and St. Lawrence Island. Billings himself afterwards landed on the Chuckchee Peninsula, Siberia, where he made a hazardous but apparently bootless journey inland. The two vessels wintered at Iliuliuk, Unalaska Island, and the following year returned to Kamchatka. The expedition, which in its preparation and execution had cost seven years of time and large sums of money, accomplished almost nothing beyond gaining some information regarding the abuse of the natives by Russian traders.

\section{RUSSIAN OCCUPATION.}

The last two decades of the eighteenth century were to witness important changes in the Russian fur trade. The Shelikof Company, after its settlement on Kodiak in 1783, gradually extended the sphere of its trading operations to the neighboring islands and mainland. In 1788 an imperial ukase granted to this company the exclusive control of the regions actually occupied by its agents. In 1792 an important step was taken in appointing Alexander Andreivich Baranof, chief director of the company's American interests. Baranof, who held this post for twenty-five years, showed himself to be a far-sighted, energetic man, though coarse and unscrupulous. The early years of his administration were a fitting introduction to the stormy ones to follow. At Cook Inlet rival traders had established themselves, who for some time quarreled and fought among themselves, but finally united to oppose their common enemy, the Shelikof Company. At length Baranof was forced to assume authority which he did not legally possess, and restored some measure of peace by arresting and imprisoning the ringleader.

In the meantime Baranof was energetically looking after the interests of the company in other directions. A shipyard was established on Prince William Sound, and attempts were made at agriculture at Kodiak and Yakutat Bay, while the fur trade was pushed vigorously. The first Greek Catholic missionaries arrived from Siberia in 1794, and at the same time the first convicts were imported and settled at Yakutat.

At the close of the century the court at St. Petersburg was beginning to be moved by reports of the disorders and outrages committed by the irresponsible fur traders, and was becoming weary of the quarrels of the rival companies. It was, moreover, desirous of maintaining Russian prestige in America by a responsible representation. Thus it happened that the Shelikof Company, with the aid of financial backing, was able to obtain a new charter under the name of the Russian. 
American Company. The imperial ukase which established this company was dated 1799, and granted exclusive privileges of trade and occupation of northwestern America, lying north of latitude $55^{\circ}$ and including the Aleutian Islands. The original grant was for twenty years, but two extensions placed Alaska in the hands of this company for sixty years. From this time on the history of Alaska up to its transfer to the United States is practically the history of this company which controlled this great monopoly. The region being now definitely in the hands of the Russians, the limits of whose possessions were determined by treaty with England in $\mathbf{1 8 2 5}$, other nations discontinued their explorations.

In its early history the Russian-American Company was too much engrossed in developing the commercial resources of its grant to make any attempts at extensive explorations or surveys. However, as its agents gradually enlarged their field of operations, they gained some knowledge of new areas. The hunting trips had already reached southeastern Alaska, and in 1799 Fort Archangel Gabriel was built on Baranof Island, in Sitka Bay. The warlike Thlinkets of this region were far from submitting to Russian transgressions as did the Aleuts, and during the entire Russian occupation they proved themselves aggressive neighbors. In 1802 they attacked and demolished Fort Archangel Gabriel, and the few survivors were only saved by the timely arrival of an English vessel. Two years later Baranof set upon the Thlinkets in force and drove them out of their stronghold, Sitka, of which he took possession. He soon moved the capital of the colony from Kodiak to this new post, which he called New Archangel.

During the early part of the nineteenth century the activities of the colony, under Baranof's directorship, were in the main confined to commercial lines. But several minor explorations were undertaken, chiefly by naval officers who were in the service of the company. Thus it happened that Khwostof and Davidof made investigations among the Aleutian Islands in 1802. In the following year Bassanof visited the Copper River; and surveys were made in the Alexander Archipelago and the vicinity of Kodiak by Captains Krusenstern and Lisiansky in 1804 and 1805.

When Captain Golofnin of the Russian Navy was sent out by the home government in 1810, and a second time in 1818, for the purpose of investigating the affairs of the company and the status of the natives, some contribution was again made to geographic knowledge, though only incidentally.

The most important exploring voyage of this period was undertaken in the brig Rurik by Otto von Kotzebue, of the Russian navy. His purpose was the general advancement of scientific knowledge, including the discovery of a northeast waterway, in the existence of which many geographers still obstinately believed. Sailing from Kronstadt in 1815 , Kotzebue reached Kamchatka the following year, whence he headed for Bering Strait. He touched at St. Lawrence Island, rounded Cape Prince of Wales, and coasting along the north side of the Seward Peninsula entered and surveyed the great sound which bears his name. On his return passage he visited Unalaska. After wintering in the Hawaiian Islands Kotzebue made a second trip to Alaska, but did not extend his former surveys.

No systematic explorations or surveys had been attempted under Baranof, but a change came about when the directorship of the Russian-American colony was transferred to naval officers, several of whom were men of scientific tastes and 
training and did much to foster geographic investigations. Other sciences were not neglected; systematic meteorologic records were kept at Sitka for many years, and a magnetic station was also maintained. Of the directors of the colony Baron F. $P$. von Wrangell was most prominent. Coming to his post fresh from Arctic explorations, he naturally looked with favor on all geographic investigations, and it was under his régime that the most important of the explorations carried on by the compuny were undertaken. This work was actively furthered by one of Wrangell's successors, Capt. Michael D. Tebenkof, who was also an explorer. Tebenkof's atlas of the northwestern coast of America, comprising a summary of all previous investigations, is the most important contribution to the geography of Alaska made during the entire Russian occupation.

In 1826 began the most valuable coastal exploration made by the RussianAmerican Company. This expedition, under the direction of Kramchenko, Etolin, and Vasilief, spent two years in examining the shore line of Bristol Bay and Norton Sound. In the following year Captain Lütké, sent out by the authorities at St. Petersburg, visited Unalaska and the Pribilof Islands and made a careful survey of the northern coast of the Alaska Peninsula. The southern coast of the Alaska Peninsula was mapped a few years later by Vasilief.

Among the lesser expeditions made under the direction of the company may be mentioned the explorations of the Bristol Bay and Kuskokwim regions by Korsakof, Vasilief, and Kolmakof from 1818 to 1832, and Malakof's exploration of the Sushitna in 1834. A more important expedition was one in charge of a creole by the name of Andrei Glasunof, who crossed from the Russian post at St. Michael, Norton Bay, to the Yukon and thence to the Kuskokwim. This, with Malakof's trip up the Yukon as far as Nulato, paved the way for the exploitation of the fur trade of the Yukon River.

By far the most fruitful of the Russian inland explorations was that made by Lieutenant Zagoskin, of the Imperial navy, in 1842-43. Zagoskin ascended the Yukon as far as the mouth of the Tanana and explored the lower stretches of the Koyukuk. Under his auspices a post was built at Nulato. He also traversed the Innoko, an easterly tributary of the lower Yukon, and made his way eastward to Kuskokwim waters. As far as time and means would permit, Zagoskin made track surveys and astronomic determinations of position, meanwhile taking careful notes on the native population and the resources of the region traversed. In the light of subsequent developments it is of interest to note his statement that the Yukon, or Kwickpack as he called it, was not navigable above the mouth of the Tanana.

In the meantime activity in Arctic exploration once more drew the attention of English navigators to the northwest coast. In 1789 Alexander Mackenzie had followed to the Arctic Ocean the great river which bears his name. In 1826 Sir John Franklin had traversed the Arctic coast westward, from the mouth of the Mackenzie as far as Return Reef on the north Alaskan coast; and Capt. F. W. Beechey, of H. M. S. Blossom, who had been dispatched to cooperate with Franklin, carefully charted the southern coast of the Seward Peninsula to Cape Prince of Wales, and added many details to the work of Kotzebue in Kotzebue Sound, extending his surveys northward until blocked by ice. A boat expedition under Beechey's mate Elson succeeded in reaching Point Barrow, which, it was hoped, 
Franklin would be able to reach from the east. But as Franklin was blocked by the ice 100 miles east of Point Barrow, this part of the coast line represented a hiatus in the charts for ten years.

In 1837 Peter W.arren Dease and Thomas Simpson, of the Hudson Bay Company, descended the Mackenzie and followed the coast westward. Like Franklin, they, too, were stopped by the ice, but Simpson continued on foot and in native boats. He reached Point Barrow August 4, 1837, thus completing the exploration of the entire coast line of the mainland of Alaska, which was begun by Bering about one hundred years before.

Another impetus to Alaskan exploration was given by the series of Franklin relief expeditions which were sent out by the British Government between 1848 and 1853. While the primary purpose of these expeditions was to find and bring relief to Franklin, yet the commanders incidentally accomplished considerable exploration and charting. An added stimulus was the hope of finding a northwest passage, which geographers were loath to give up. In 1849 Capt. Thomas E. L. Moore in H. M. S. Plover, Capt. Henry Kellett in H. M. S. Herald, and the yacht Nancy Dawson, reached Kotzebue Sound. A boat expedition under Lieutenant Pullen was sent northward, and rounding Point Barrow proceeded eastward to the Mackenzie River, which it ascended to a Hudson Bay post. A second expedition from these vessels explored the Buckland River. Other minor explorations were made by the crew of the Plover while she wintered in Kotzebue Sound. Thus Lieut. Bedford Pim crossed the eastern end of Seward Peninsula to the Russian post at St. Michael, and Simpson, surgeon of the expedition, explored the Selawik River and made the first mention of the Kobuk River. The Plover spent the two following winters at Point Barrow, from which she continued to send out exploring parties.

In 1850 Commander Robert S. M. McClure, in H. M. S. Investigator, sailed eastward past Point Barrow and beyond the mouth of the Mackenzie until he was stopped by the ice. His vessel was never brought through, but eventually his crew, by walking over the solid ice, was the first to make the northwest passage. The following year Capt. Richard Collinson, in H. M. S. Enterprise, also passed Point Barrow, and subsequently wintered at Walker Bay, on the north coast of Alaska. In 1853 H. M. S. Rattlesnake, Commander Trollope, wintered at Port Clarence, on the south side of the Seward Peninsula, which some of the crew crossed during the winter.

The surveys of these Arctic expeditions were very carefully executed and are still the bases for most of the charts of the regions they cover. The accounts of the voyages are full and contain much valuable information, which up to very recent times was all that was available concerning Arctic Alaska.

In 1848 the American whaler Superior, commanded by Captain Roys, ventured through Bering Strait, and was amply rewarded by a good catch. This example was followed by many others in succeeding years. The whaling industry along the Arctic coast of Alaska has continued to be an important one up to the present day, though it received a serious setback during the civil war by the ravages committed by the Confederate privateer Shenandoah, which captured and destroyed many vessels of the American whaling fleet. Stations are now 
maintained by the whaling companies at Point Barrow and Herschel Island, east of the international boundary. The experienced seamen who usually commanded these whalers added not a little to the geographical knowledge of the Arctic coastal region of Alaska.

The only other important American contribution during the period of Russian control was furnished by Lieut. William Gibson, U. S. Navy, who, in command of the schooner Fenimore Cooper, of the Rodgers United States Northern Pacific Exploring Expedition, made surveys and explorations among the Aleutian Islands in 1855. Some of the other vessels of the same fleet passed through Bering Strait and into the Arctic Ocean.

Many years elapsed after Mackenzie made his explorations to the Pacific before the English fur trade was to establish itself near the bounds of what is now known as Alaska. Though the Hudson Bay Company was incessantly pushing its outposts to the west, it did not reach the drainage basins of rivers which emptied into the sea through the Russian American possessions until toward the middle of the nineteenth century. Campbell established a Hudson Bay post in 1840 on the headwaters of the Pelly, a branch of the Yukon, and eight years later (1848) built Fort Selkirk, at the mouth of the Pelly. In the previous year, however, Fort Yukon had been built at the mouth of the Porcupine by A. H. Murray, another Hudson Bay agent. The English traders of these posts soon learned through the natives that the Russians were in possession of the lower river, and, probably about 1850, some of them made a trip down the Yukon to the mouth of the Tanana, which was the uppermost point reached by the Russians in their trading expeditions. This was also the point reached by the explorer Zagoskin in his ascent of the river in 1843. It can therefore be stated that the preliminary exploration of the main Yukon by white men was completed by this journey of the Hudson Bay traders, though its first mapping remained to be done by the members of the scientific corps of the Western Union Telegraph Expedition.

In 1834 the Hudson Bay Company had by high-handed proceedings attempted to establish itself within Russian America, in what is now called southeastern Alaska, but it was promptly ejected by the Russian Company. After a conference this coastal belt was, in 1837, leased by the Russians to the Hudson Bay Company for a term of ten years. The Hudson Bay Company, from its two posts in the Yukon drainage basin, controlled the fur trade of the upper river, while the Russian-American Company controlled the trade on the lower river.

One other expedition needs mention-the last of the Russian official surveys in America. In 1863, word having been received at Sitka that American prospectors had found gold on the Stikine River, it was decided to send out an expedition to find out whether these discoveries were in Russian territory. This party, in command of Commander Bassarguine, of the Imperial navy, and accompanied by the American geologist, William P. Blake, made a reconnaissance survey of the lower part of the Stikine.

In 1863 the Western Union Telegraph Company determined to build an overland telegraph line from the western coast of the United States through British Columbia and what was then known as Russian America to Bering Strait. This line was to be connected by cable with a trans-Siberian line, and thus telegraphic 
communication was to be established between America and Europe. The project, first conceived by Percy M. D. Collins, was a daring one, for it contemplated the building and maintaining of a telegraph line through thousands of miles of almost unexplored territory in America and Asia. The first essential to the project was preliminary exploration of the proposed route. The success of the Atlantic cable led to an abandonment of the enterprise only three years after its organization, but even in that short time important contributions were made to a geographic knowledge of Alaska and adjacent portions of Canadian territory. The explorations in Siberia were also fruitful of important results.

The task which confronted the Western Union Telegraph survey in Russian America was not an easy one. The region to be explored was several thousand miles distant from the nearest port of the United States. While there were some Russian trading posts on Bering Sea and along the lower Yukon, they were widely separated and the Russian knowledge of the interior was practically limited to the lower part of the Yukon and the Kuskokwim. Moreover, the Russian outposts were small and ill equipped, so that practically all supplies had to be taken from the Pacific coast ports of the United States.

Robert Kennicott was chosen as head of the scientific corps, serving under Capt. Charles S. Buckley, engineer in chief of the expedition. Kennicott was a fortunate choice, as he was an able and enthusiastic worker and his previous expedition into the far northwest, in 1860-61, when he had reached Fort Yukon by following the Hudson Bay Company route from the Mackenzie, had fitted him well for the undertaking. He did not live to see the execution of his comprehensive plans, for he died. at Nulato in 1866, his death being brought about by the incessant toil and exposure to which he had been subjected. William H. Dall, who took the leadership of the scientific corps, continued alone his researches on Norton Sound and the lower Yukon after the telegraph survey party was disbanded. His book, based on these investigations, and the reports which he wrote later under the auspices of the Coast Survey, are still the standard works on Alaska.

In 1865 Robert Kennicott, Frank Ketchum, and Michael Lebarge had started up the Yukon. After Kennicott's death at Nulato in 1866 Ketchum and Lebarge pushed on up the river to Fort Yukon. In the following year they continued their explorations as far as Fort Selkirk, at the junction of the Lewes and Pelly rivers. Dall and Frederick Whymper reached Fort Yukon in the summer of 1867, after making the first survey of the lower Yukon. In the meanwhile, in 1865, Baron Otto von Bendeleben and W. H. Ennis, also of the telegraph survey, made an exploration from Golofnin Bay to Port Clarence, and J. T. Dyer and Richard D. Cotter crossed overland from Norton Bay to the mouth of the Koyukuk, while Capt. E. E. Smith carried on surveys in the delta of the Yukon.

The geographical results of this survey in Alaska are a map of the Yukon River, definitely establishing the identity of the Yukon of the Hudson Bay Company with the Kwikpak of the Russians, and important additions to the knowledge of the Yukon Delta, Seward Peninsula, and the Norton Bay region. It is interesting to note that the route which these first explorers selected has been practically adopted by the telegraph lines which are now being constructed in Alaska and in Canadian territory. Of still greater importance even than the actual surveys 
was the more or less exact information which the telegraph survey explorers were able to furnish the American public during and after the negotiations by which Russian America became an American possession.

\section{AMERICAN OCCUPATION.}

In 1867 the territory of Russian America passed into the hands of the United States, the treaty being ratified by the Senate on May 28. The territory, which at the suggestion of Secretary Seward was called Alaska, was purchased from Russia for $\$ 7,200,000$.

At the time of the transfer of Alaska to the United States the coast line had practically been explored throughout and much of it had been charted with a fair degree of accuracy. While the Russian explorations of the coast added many details, it can not be denied that the larger part of this work had been done by half a dozen English navigators-Cook, Vancouver, Beechey, Franklin, Dease, and Simpson. Many of the surveys made by these men have not been duplicated and are still the basis for all of the existing charts. Soon after the transfer the Coast and Geodetic Survey took up the task of charting the coast line of Alaska, on which it has been actively engaged ever since. The magnitude of this task is shown by the fact that the length of the coast line exceeds 20,000 miles. Other Government vessels, such as those of the Revenue-Marine Service, Fish Commission, and Navy, have at various times made contributions to the knowledge of Alaskan coastwise navigation. The results of all of these surveys are embodied in the charts and coast pilots published by the Coast and Geodetic Survey.

Prior to the transfer in 1867, little was known of the interior of Alaska. The Russians had ascended the Yukon for 1,000 miles and the Kuskokwim for 500 miles; had mapped the lower stretches of the Stikine; had ascended the Sushitna a short distance, and had made an abortive attempt to explore the Copper River. They were also familiar with the Alaska Peninsula and the Iliamna Lake region. Following the routes which had been marked out by such explorers as Franklin and Mackenzie, the Hudson Bay Company traders had reached the Mackenzie River, and in the middle of the nineteenth century crossed to the Yukon waters. The telegraph surveys explored the entire length of the Yukon as now defined and made some additions to the knowledge of the geography of the Seward Peninsula. Outside of these explorations, which were practically confined to the lower regions of some of the larger rivers, the newly acquired territory was an unknown land.

On October 18, 1867, the Russian flag was lowered from the flagstaff in front of the governor's residence at Sitka and the United States flag hoisted amidst the booming of cannon. This was the act of formal transfer by which Russian America became Alaska and a possession of the United States. At a number of points in southeastern Alaska and Kodiak extensive barracks were erected and occupied by United States troops, while an army officer represented the Federal Government. But ten years later all troops were withdrawn and for a number of years the country was governed by a naval officer stationed at Sitka. Then even this control lapsed, and Alaska was left for a time in the anomalous position 
of being without either military or civil government. Finally, in 1884, the first civil code for Alaska was enacted, and this has been modified from time to time by Congressional statute. Though Alaska has been in possession of the United States for upward of a third of a century and has a population of 62,000 , it has not yet been granted even a Territorial form of government, being still to all intents and purposes a colony.

As soon as Alaska was transferred to the United States the Coast Survey began to gather notes on its geography, and since has been steadily engaged in charting the shore line and compiling information valuable to navigation. Notable among the first officers of the Coast Survey to investigate Alaska are Prof. George Davidson and Dr. William H. Dall. Mr. Marcus Baker assisted Doctor Dall in this work for several years. He later took up the cartographic study of Alaska, and in 1900 made an important contribution to the knowledge of the Territory by his Geographic Dictionary of Alaska.

Many of the reconnaissance surveys of the coast line were made by naval officers attached to naval or Coast Survey vessels. Much was added to the knowledge of the coast geography by the cruises of the vessels of the RevenueMarine Service. Besides these surveys, other Government investigation led to reports on sea fisheries, fur trade, and resources in general, but it is not within the province of this paper to make mention of all of these.

Americans were quick to seize the opportunity for trade which the resources of Alaska offered. The interests of the Russian-American Company were purchased by a strong corporation, and other ventures were made by individual merchants. In 1869 a steamboat was first used on the Yukon for trading purposes. During the succeeding decade several posts were established on the lower Yukon, which were annually visited by a steamer making one trip each season from the mouth of the river.

When Alaska first passed into the possession of the United States, little attempt was made to explore the interior. In 1869 Capt. C. W. Raymond, U. S. Army, was sent up the Yukon to determine the approximate position of the international boundary, and thus settle the conflicting interests of American and British traders. The results of the expedition were published in the form of a report, giving data in regard to natives and fur trade, and accompanied by a map of the lower Yukon which was an improvement on that of the telegraph survey, inasmuch as it included several points whose latitudes Raymond had fixed by astronomic observation.

The names of a small group of pioneer traders who some time in the early seventies entered the Yukon basin via the Hudson Bay Company route from the Mackenzie are known throughout Alaska. Conspicuous among these were Jack McQuesten, Arthur Harper, Fred Mayo, Fred Hart, Joe Ladue, and Frank Densmore. These men made many hazardous journeys without any of the aids of the modern explorer, dependent simply on their own resources. They left but few records of these journeys, but we know that Harper visited the White and Tanana, McQuesten the Koyukuk, and Frank Densmore the Kuskokwim; and the knowledge obtained by them entirely through their own efforts or through their intercourse with the natives 
was later in part embodied in maps of Alaska and in part preserved by word of mouth, and when the prospectors descended the Yukon, in the eighties, it proved of great assistance to them.

Gold was reported on the Yukon as early as the teleyraph survey of 1867, but does not seem to have been found in workable quantities for many years later. Just when the first systematic prospecting was done is somewhat uncertain, but it is known that some time between 1873 and 1878 George Holt made his way inland over the Chilkoot Pass and descended the Lewes River. By some reports he is said to have descended the river below Fort Yukon at this time. It seems certain, however, whatever the date of his journey, that this was the first systematic attempt at prospecting on the Yukon.

The Chilkoot Indians, fearing that their lucrative trade with the interior natives would be interfered with, were strongly opposed to allowing white men to cross the coast mountains by their trading route over the Chilkoot Pass. Through the intervention of Captain Beardslee, who commanded the U. S. S. Jamestown, this opposition was at length withdrawn, and in 1880 a party of 16 miners, under the leadership of Edmund Bean, crossed the Chilkoot Pass and descended the Lewes as far as the Teslin. These were followed by others who in the next few years traversed the entire length of the Lewes and the Yukon. It was not, however, until 1885 and 1886 that important finds of gold were made.

In $1879 \mathrm{Mr}$. John Muir and Rev. S. Hall Young visited Muir Glacier and explored Glacier Bay. They were the first white men to examine the bay, though it had been seen in 1877 by Lieut. C. S. A. Wood, while making some explorations in the Fairweather Mountains in company with some native hunters. Muir's published descriptions of the wonders of Alaskan scenery drew much public notice and led in later years to the development of a favorite tourist route through southeastern Alaska.

The most notable contribution to the knowledge of the geography and resources of Alaska was made by Iran Petrof, an agent of the Tenth Census, who had long been a resident of the territory. He spent two years in traveling along the coast and on the lower Yukon and Kuskokwim, his familiarity with the native tribes and the Russian inhabitants enabling him to obtain much valuable data regarding regions not visited by him. His results and those of the several other experienced men who were employed in this work were compiled by Petrof in an admirable report and published by the Census Office. His general map of Alaska which accompanied this report, though largely based on the statements of natives and traders, was remarkably accurate in delineating the general features of the geography. He seems to have been the first man to have a clear conception of the distribution of the mountain ranges in Alaska. In judging Petrof's geography, it must be remembered that outside of rough traverses of the Yukon and the lower Kuskokwim the interior of Alaska was known only through the reports of a few traders.

The Indian route to the headwater's of the Yukon had been in use by prospectors for at least two years when Lieut. Frederick Schwatka traversed it in 1883. He crossed the Chilkoot Pass (called by him Perrier Pass) with a small party, and built a raft at the headwaters of the Lewes and continued down the river in this 
unmanageable craft, running the various rapids, ${ }^{a}$ to Fort Selkirk at the junction of the Pelly and Lewes. From this point on he was traversing a river which had been explored by the Western Union Telegraph agents and was already occupied by the fur traders. Schwatka continued his trip to Fort Yukon and thence to the sea. To Charles W. Homan, who accompanied Schwatka as topographer and made sketch surveys throughout the entire journey, correcting them by observations for latitude, belongs the credit of having made the first actual survey of the Yukon and Lewes rivers. Crude as it was, it has only in very recent years been superseded by better work. Schwatka's rather spectacular account of his trip down Alaska's great river, a journey which had been made by many others, did much to rouse public interest in this far away region, and in the course of the following decade a number of exploring parties were sent out.

During the years 1881-1883 a meteorological and magnetic station, in charge of Lieut. P. H. Ray, was maintained at Point Barrow by the United States Signal Service. No explorations or surveys of any importance were attempted.

Dr. Arthur Krause of the Geographical Society of Bremen, Germany, in 1881, made a journey from the coast at Lynn Canal into the Chilkoot River basin. He subsequently published a map which for more than ten years was the basis for all other maps of the region visited by him.

In 1884 Lieut. W. R. Abercrombie, U. S. Army, was detailed to make an exploration of the Copper River. He ascended it a short distance, but his expedition may be looked upon as an entire failure. This work was taken up again in the following year by Lieut. Henry $\mathrm{T}$. Allen, who made one of the most remarkable journeys in the annals of Alaskan explorations. Allen, with four men, landed at the mouth of the Copper River in March, 1885, and made his way up that stream by boat and sled for about 300 miles; then crossed to the Tanana by way of the Suslota Pass, and securing another boat from the natives, continued his journey to the mouth of the Tanana. During this part of the journey the party was dependent entirely upon the country for food, and were in a half-starved condition when they reached the Yukon about the end of June. With indefatigable energy Allen then, with one companion, crossed to the Koyukuk from near the mouth of the Melozi River, and explored it almost from the Arctic Circle to its junction with the Yukon. Crossing by portage from the lower Yukon to Norton Sound, he made his way to St. Michael, whence he returned by steamer to the United States. No man through his own explorations has added more to a geographic knowledge of the interior of Alaska than Lieutenant Allen. Throughout his journey he made careful sketch surveys and noted all facts which came within his observation; and within one season he mude maps of three of the larger rivers of the Territory, which, until accurate surveys were made twelve years later, were the basis of all maps. His reports are the work of a careful, painstaking observer, who did his utmost to gain all the information possible.

During the years 1883 to 1886 extensive explorations were made by officers of the Navy and of the Revenue-Marine Service along the rivers tributary to Kotzebue

a Schwatka portaged his outfit around Miles Canyon and White Horse Rapids. The raft was allowed to drift through and was caught below. 
Sound. These led to a more general knowledge of this remote part of Alaska than of parts which were far more accessible.

In 1883 Lieut. George M. Stoney, who was sent to the coast of northeastern Siberia on the revenue steamer Comwin to distribute presents to the natives who had aided the Jeannette relief expedition, examined the vicinity of Kotzebue Sound, and with the aid of some natives explored the delta of the Kobuk River, which Simpson had learned of in 1850. Having interested the Navy Department in these explorations, Stoney returned in the following year, and with the aid of a steam cutter and a native boat managed to ascend the Kobuk to the mouth of the Soolukpowaktoark River, and continued up that stream to its source in Walker Lake. In the same year Ensign Purcell of the Stoney party explored Selawik Lake.

A third trip into this region was made by Stoney in 1886, this time accompanied by a large and well-equipped party, which established winter quarters on the Kobuk, about 250 miles from its mouth, and spent the winter in extensive explorations. Stoney explored the headwaters of the Noatak and of the Alatna, the latter a tributary of the Koyukuk, and reached the head of the Selawik River, south of the Kobuk, and Chandler Lake, in which the Colville River has its source. Some of Stoney's officers made trips into the interior. Ensign Reed led a party from the winter camp to the Noatak River, and Assistant Engineer Zane reached the Yukon by way of the Pah and Koyukuk rivers; but the most noteworthy trip was that made to Point Barrow by Ensign W. L. Howard. He left the winter camp in April with two white men and two natives and proceeded northeast across the Noatak to the valley of the Colville, followed this downstream in company with a party of natives for about 20 miles, and then crossed to the headwaters of Chipp River. Here he discarded the dog teams used up to this point for transporting his supplies, and descended the Chipp River to the coast in native skin boats, arriving at Point Barrow on July 15, being the first white man to cross northern Alaska. The results of the expedition were a fairly accurate survey of the Kobuk Valley and sketch maps of the Selawik, upper Colville, upper Noatak, and Alatna rivers. Stoney's was the first attempt at instrumental surveys in the interior of Alaska.

In 1884 Lieut. John C. Cantwell, of the Revenue-Marine Service, explored the Kobuk as far as the mouth of the Black River. In the following year Cantwell succeeded, by using at first a steam launch and afterwards a skin boat, in reaching Walker Lake, near the head of the Kobuk. He was the first white man to reach the upper Kobuk, and, considering the conditions under which the trip was made, prepared a very creditable map of the river. Mr. Charles H. Townsend, of the United States Fish Commission, accompanied the party as nuturalist. Another officer of the Revenue-Marine Service, S. B. McLenigan, made an exploration in this region in 1885 . With one companion he ascended the Noatak River about 300 miles in a native skin boat, carrying out his instructions in the face of many obstacles and maintaining a sketch survey throughout his journey. His map has not yet been superseded by more accurate surveys.

Mount St. Elias has long been a subject of great popular interest, both because of its altitude, it being at one time considered the highest peak on the continent, 
and because it was the first point sighted by a white man on the mainland oi Alaska. Bering, who discovered and named it, knew it only as a distant peak whicb loomed above the clouds, for he made no attempt to get near it. The mountain was also noted by Cook, Dixon, and Vancouver during their explorations of the coast line. In 1786 La Perouse, while cruising along the coast, saw Mount St. Elias, and Dagelet, his astronomer, calculated its altitude at 12,672 feet. Five years later Malaspina entered Yakutat Bay and surveyed Disenchantment Bay, its inland extension, which he hoped would prove to be a northeast passage. His determination of the altitude of the mountain as 17,851 feet came remarkably near the truth, considering the adverse conditions under which it was made. In 1737 Sir Edward Belcher visited Yakutat Bay in H. M. S. Sulphur. Tebenkof's Atlas, published in 1852, gives the altitude of the mountain as 17,000 feet. In 1874 Dall and Baker, while cruising along the coast, made a rough triangulation and reported the altitude of the mountain at over 19,000 feet.

It was nearly a century and a half after Bering's discovery before any attempt was made to ascend the mountain or even to approach its base. In 1886 Frederick Schwatka, with Prof. William Libbey and Lieut. H. W. Seton-Karr, led an expedition, which was supported by the New York Times, to make the ascent of the mountain. So little was known of the conditions of travel that the party was foredoomed to disaster. Schwatka and Seton-Karr, with a small party, reached a point about 20 miles inland and obtained considerable geographical information which was of great use to the subsequent explorers. Two years later an altitude of 11,400 feet was attained by a party consisting of W. H. Topham, Edwin Topham, and George Broca, Englishmen, and William Williams, an American. A third attempt was made in 1890 by I. C. Russell and Mark B. Karr, with six camp hands, under the joint auspices of the National Geographic Society and the United States Geological Survey, which, though unsuccessful, resulted in some important contributions to the geographic knowledge of the region. Russell and Karr would undoubtedly have reached the top had not a severe storm forced them to retreat after waiting four days in rude shelters in snow banks on the upper slopes of the mountain without fuel and almost without food. Russell, nothing daunted by this experience, in 1891 again essayed the ascent under the same auspices. During this attempt he succeeded in reaching a height of 14,500 feet, but was again forced to return by severe storms. The results of Russell's two expeditions were a large amount of data in regard to the glacial history of the region and a fairly accurate map of the slope of the mountain. His determination of 18,100 feet as its height proved to be remarkably accurate, if one takes into account the conditions with which he had to contend. The Coast Survey triangulation of the following year shows the elevation to be 18,024 .

The summit of St. Elias was reached by an Italian, Prince Luigi, who followed the route which Russell had explored and very largely adopted the methods which Russell had recommended. Luigi, in 1897, landed at Yakutat Bay, and with a large, thoroughly equipped expedition made his way across the 40 miles of snow and ice between the coast and the base of the mountain. In his ascent he practically followed Russell's route, reaching the summit July 31, five weeks after leaving tidewater. Prince Luigi's expedition was carefully planned, and he showed 
himself a capable leader as well as an experienced mountaineer. The report ${ }^{a}$ of the expedition contains much that is of geographic interest, but is chiefly valuable as a contribution to the literature of mountaineering.

The location of the international boundary on the Yukon became a question of importance after the discovery of rich gold placers near it. The Canadians were first in the field. In 1888 William Ogilvie and George M. Dawson made surveys of the route from the head of Lynn Canal, in southeastern Alaska, to the mouth of the Lewes River. Ogilvie in the following year extended his surveys down the Yukon to the international boundary, and in 1890 continued his exploration to the head of the Porcupine, which had been surveyed in the previous year by R. G. McConnell, of the Canadian Survey.

Meanwhile the United States Coast and. Geodetic Survey had dispatched two parties to the boundary. One of these, under J. E. McGrath, established an astronomic station near the boundary on the Yukon, and the other, under J. H. Turner, made a similar station where the boundary crossed the Porcupine. In connection with this work Turner's party in 1890 made a winter trip with dog teams from the camp on the Porcupine to the Arctic Ocean, following as nearly as possible the one hundred and forty-first meridian. This was the second time that northern Alaska was crossed by white men, the first being three years before by Ensign Howard. McGrath and Turner's surveys were limited to very small areas, but are of general geographic interest, as they represent the first geodetic surveys in the interior of Alaska. Besides the work to which they had been specially detailed, they also kept meteorologic records and made corrections from their route traverses in the existing maps of the Yukon. Prof. I. C. Russell, of the United States Geological Survey, accompanied McGrath to the boundary from the mouth of the river, and thence came to the coast with a party of prospectors by way of Lewes River and the Chilkoot Pass.

In 1890 an expedition was sent out by Frank Leslie's Weekly for explorations in Alaska. The writer has been unable to discover any account of the work of this party. It apparently left the coast at Pyramid Harbor, ascended the Chilkat River, and after crossing the divide explored Lake Kusawa. There the party divided and A. B. Schanz and S. J. Wells descended to the Yukon, while E. J. Glave and Jack Dalton crossed the divide to Alsek waters, and followed the Alsek River to the coast. Later in the season Wells made a trip down the Tanana, and Schanz is said to have visited lakes Clark and Iliamna during the following winter. Glave and Dalton's exploration of the Alsek was a daring piece of work, as its character at that time was entirely unknown. Its course through the St. Elias Range has not even yet been surveyed.

In 1891 Schwatka made his third trip to Alaska. Schwatka, C. Willard Hayes, of the United States Geological Survey, and Mark Russell, a prospector, ascended the Taku River, crossed the divide to Teslin Lake, and in folding canoes, which had been transported across the pass by natives, went downstream to the Lewes River and continued to Fort Selkirk, on the Yukon. Crossing overland to the White

$a$ It is somewhat surprising that in the account of this expedition it should be gravely stated that the barometric determination of the altitude of Mount St. Elias of 18,090 feet should be regarded as more accurate than the previous instrumental determinations by Russell. As a matter of fact, J. E. McGrath, of U. 8. Coast and Geodotic Survey in 1892, had fixed the height of Mount St. Elias at 18,024 feet by triangulation.

$$
17211 \text {-No. } 45-06-9
$$


River, near the point where it is intersected by the international bcundary, they then continued up the White to its source; and though they were deserted by all of their Indian packers, the three white men of the party went on through Skolai Pass, and, after reaching navigable waters on the Nizina, built a boat and continued down to the Copper River. Doctor Hayes's report and map, which are based on a foot traverse, are remarkably complete and accurate considering the exceedingly trying conditions under which the field observations were made, and give much geologic and geographic information about a region which up to the time of its publication was practically unknown.

In that same year Glave (who later lost his life on the Congo) and Dalton made a second trip into the Alsek basin. This time they are said to have extended their journey westward to the White River basin, but the map accompanying Glave's published account is very inaccurate. The exploit is of interest chiefly because it was the first time in the history of the country that horses were used on an extended journey.

Congress, in 1895, tardily recognized the importance of an investigation of the mineral resources of Alaska, and by a small appropriation enabled the Geological Survey to send its first party to the north. Dr. George F. Becker, aided by C. W. Purington, made a preliminary investigation of the gold deposits, and W. H. Dall studied the coal deposits of the Pacific coastal belt. The following year J. E. Spurr, with H. B. Goodrich and F. C. Schrader, descended the Yukon and visited the more important placers of Alaska and did some topographic as well as geologic mapping.

Even thirty years after its accession the mass of the public was still almost entirely ignorant of the geography, resources, or climate of Alaska. Well-informed people regarded it as a region of perpetual snow and ice, the land of the fur trader, Indian, and Eskimo. A great change was wrought by George W. Carmack's discovery of gold on the Klondike River, in Yukon Territory, during the summer of 1896. This event led to the development of the famous Klondike placer field, which in one year brought more than 50,000 people into Alaska and the adjacent portions of Canadian territory, and made the name Klondike a household word in every civilized country on the globe. Hardly had the Klondike excitement subsided somewhat when the discovery of the Nome placer fields in 1898 again attracted the attention of the world to Alaska, and a second exodus to this northern region took place.

Of the thousands who entered the Yukon basin during the first years of the gold excitement, but a small percentage had any conception of the difficulties with which they would be confronted, and still less had any previous training which fitted them for the work they had so rashly undertaken. Hundreds toiled over the Coast Range passes and made the mad dash to reach the Eldorado their fancies had painted, but, discouraged at the outlook, continued down the Yukon to its mouth, having hardly been out of sight of its banks. The more venturesome prospector, however, found no risk too hazardous, no difficulty too great, and now there is hardly a stream which has not been panned by him, and hardly a forest which has not resounded to the blows of his ax. Evidences of his presence are to be found from the almost tropical jungles of southeastern Alaska to the barren grounds of the north which skirt the Arctic Ocean. While the prospectors have traveled far and wide in Alaska, they 
have as a class added little to the knowledge of its geography. As a rule they follow but two purposes, one to find gold and the other to get through the country. The information obtained by them is seldom exact, even when available, for their conception of where they have been is often as vague as their ideas as to where they are going. Though their contribution to geographic knowledge is small, these pioneer prospectors, at the expense of hard toil and suffering, if not of their lives, have blazed the way for the settler, miner, and surveyor.

The public interest aroused in Alaska by the finding of valuable placer mines in adjacent territory led to a demand for more definite information, and money was appropriated for investigation in Alaska under various bureaus of the Federal Government. The Coast and Geodetic Survey was enabled to expand its Alaskan surveys, which had been carried on ever since the purchase of the Territory. The Army established military posts to preserve order and to extend relief to the many ill-equipped and inexperienced Argonauts. It also built trails and telegraph lines, which were to become of immeasurable advantage to Alaska, and even attempted some explorations and surveys, but these were only partially successful.

When in 1898 the Geological Survey ${ }^{a}$ began its systematic surveys and explorations in the interior of Alaska the problems which confronted it were not easy. The public demanded the immediate publication of maps of unexplored or only partially explored regions. Such maps would have far greater value if they could be furnished while the excitement was at its height, so there was not opportunity for extensive areal mapping. The problem was to make surveys of the main routes of travel, which were chiefly confined to the larger rivers, and to include with these as wide areas as possible. The first season's work resulted in about 3,000 miles of instrumental traverses, with reconnaissance maps of an area of nearly 30,000 square miles, besides more accurate survey of about 2,000 square miles. These traverses were largely confined to the more important rivers. The work had to be planned with a very incomplete knowledge of the geography and of the climate and other conditions of travel of the region, and all supplies and equipment had to be transported from Puget Sound ports. After landing in Alaska the parties were entirely dependent on their own resources for transportation. The first year they made their way by following the waterways in canoes, which were carried on the backs of the men at portages, but after some knowledge of the country was gained it was found that horses could be used to advantage for the transportation of supplies.

The general scheme of operations for the first year included exploration of the Kuskokwim, the Sushitna, and the Copper rivers, as all three of these streams offered possible routes into the interior. The Copper River work was carried on by members of the Geological Survey under the auspices of the War Department, which organized two expeditions for the purpose, one under Capt. Edwin F. Glenn and the other under Capt. William R. Abercrombie.

Glenn, with a small detachment provided with pack horses, left the coast at Cook Inlet and made his way northward along the Matanuska, crossed the

a Between 1898 and 1902 the following officers of the Geological Survey took part in the Alaskan work: E. C. Barnard, Alfred H. Brooks, Arthur J. Collier, George H. Eldridge, T. G. Gerdine, W. C. Mendenhall, Robert Muldrow, W. J. Peters W. S. Post, D. L. Reaburn, G. B. Richardson, F. C. Schrader, Arthur C. Spencer, J. E. Spurr, and D. C. Witherspoon. 
Copper River Plateau, and descended the Delta River to the Tanana, whence he returned to the coast by the same route. No surveys whatever were made by Glenn, but, fortunately, Mendenhall, of the Geological Survey, who had been detailed to his party, was enabled to carry on a route traverse throughout the journey. Mendenhall's map and report formed a valuable contribution to the knowledge of the geography of Alaska. At the Tanana Lieut. J. C. Castner was detached from Glenn's party to continue the exploration to Circle, on the Yukon. With two men he crossed the Tanana and attempted to make his way up Volkmar River, but the lateness of the season made the plan impracticable. After losing both their horses the three attempted to return to the Tanana on a raft. Their raft was wrecked and everything lost, including their shoes; they reached the Tanana half dead with hunger and exposure, and were fortunate enough to find some friendly Indians. The journey which had cost so much suffering and privation yielded practically nothing of value. Some minor explorations were carried on by Lieut. H. G. Learnard and Sergt. William Yanert, also of Glenn's party.

The second army expedition, under Captain Abercrombie, landed at Valdez, on Prince William Sound. The heavy snowfall prevented an early start, but eventually the entire party, including horses, made its way inland by the Valdez Glacier route, which that year was used by hundreds of prospectors. After reaching the Copper, Captain Abercrombie left the party for a burried trip to the Mentasta Pass along the trail established by prospectors. Lieut. P. G. Lowe, following a similar route, made his way to Fortymile, and returned to the coast by way of the Lewes River and the White Pass Railway. The rest of the party, under the leadership of F. C. Schrader, of the Geological Survey, did some very creditable work in making surveys and investigations in the lower part of the Copper River basin.

The exploration of the Sushitna was undertaken by Eldridge and Muldrow, of the Geological Survey, with five men. They made their way up the river from Cook Inlet, dragging their supplies in canoes against the swift current. At Jack River the boats were left, and with packs on their backs the party pushed on to the Cantwell River, confluent to the Tanana, but at this point were forced to turn back by the failure of provisions, and reached their boats in a half-starved condition. Surveys were made throughout the journey, and the position and height of Mount McKinley were determined.

The longest exploration of 1898 was that made by Spurr and Post, who ascended the Yentna, the left fork of the Sushitna, and portaging to Kuskokwim waters, descended the latter river to its mouth, and returned to Cook Inlet by a route which crossed the Alaska Peninsula.

The same year the two most important southern branches of the Yukon-the Tanana and White rivers-were surveyed. A party led by Peters and Brooks crossed the Chilkoot Pass and went inland on the snow and ice to Lake Marsh, where, after delaying until the ice broke up, they embarked in canoes for the White River, at which point the surveys began. The ascent of the river was made by dragging the canoes against the rushing current. Six weeks of this toilsome task in the glacial waters brought the party near the head of Snag River, a northern tribu- 
tary of the White, whence the Tanana was reached by portage, after which the downstream trip to the Yukon was comparatively easy. Exploratory surveys of about 10,000 square miles were made by this party. The same year Barnard, following a similar route from the coast to the Yukon, made a survey of about 2,000 square miles in the Fortymile River basin.

In 1899 Peters and Brooks continued their explorations by a survey extending westward from Lyun Canal along the northern base of the St. Elias Range to the headwaters of the White and Tanana rivers and northward to the Yukon at Forty. mile. The journey was made with horses, only five out of the original fifteen reaching the Yukon.

In this year the work of exploring the great waterways was extended north of the Yukon to the Koyukuk, which was mapped by Schrader and Gerdine. Leaving Fort Yukon in canoes, they ascended the Chandlar River, and after making a 16-mile portage reached Koyukuk waters and followed them to the Yukon.

In the fall Schrader and Brooks met at St. Michael and after the close of the work decided to visit the newly discovered placers at Nome. The investigations, while very hastily made, had their value, because they enabled the Geological Survey to publish a report containing authentic information before the exodus to the new gold fields, which took place in the following spring.

The great demand for maps of important mining districts, in 1900, forced the Geological Survey to postpone further explorations. One party, under the leadership of Schrader, Gerdine, and Spencer, mapped a large area in the Copper River basin, both geologically and topographically, while Barnard, Brooks, Peters, and Mendenhall did similar work in Seward Peninsula.

In 1901 the work in northern Alaska was resumed, and a network of surveys completed connecting the Yukon, Koyukuk, and Kobuk rivers, the Arctic Ocean and Kotzebue Sound. Schrader and Peters made a trip which included a journey the entire length of Alaska from its southernmost limit to Point Barrow. Starting in winter, they traveled to the Koyukuk with dog teams, thence ascended one of the north forks of that stream with canoes, crossed to a branch of the Colville, and followed it to its mouth. They then skirted the coast westward to Point Barrow and finally southward to Cape Lisburne, where they were so fortunate as to find a steamer. In course of their journey they traversed the Endicott Mountains, and brought back the first authentic information in regard to this great range. Theirs was probably the most notable exploration which has been made by the Geological Survey. In the same year Mendenhall and Reaburn also made surveys and explorations in this northern region. They reached the mouth of Dall River on the Yukon in June, ascended that stream in canoes, and then by an 18-mile portage reached Koyukuk waters. They descended the Koyukuk to the mouth of Alatna River, which they ascended for about 100 miles, and then made a second portage which brought them to the Kobuk River, which they followed to its mouth. This expedition is of particular interest in that it made the first instrumental survey from the Yukon to tide water. The topographic survey was begun at Fort Yukon and carried through to Kotzebue Sound. It established an altitude of 500 feet for the river at Fort Yukon, which is probably approximately correct. 
During the same season Brooks was engaged in geologic studies in southeastern Alaska, and Gerdine, Collier, and Witherspoon did areal mapping in the Seward Peninsula.

The work for 1902 was planned to include an exploration of the largest unexplored area in southern Alaska, and the running of a traverse to the Yukon which should connect the previous surveys of the Sushitna, Kuskokwim, and Tanana. To this end a party led by Brooks and Reaburn extended a survey northwest from Cook Inlet through the Alaska Range, and bending northeast passed close to the base of Mount McKinley and on to the Cantwell River, whence they took a northwesterly route across the Tanana to Rampart on the Yukon. During the same season the areal mapping of the Copper River basin was concluded by parties led by Schrader, Gerdine, Mendenhall, and Witherspoon, while Collier studied the geology of the Yukon, and Peters made a detailed topographic survey near Juneau.

()f the twenty or more parties which the Geological Survey has sent to Alaska, hardly a single one has failed to execute the work allotted to it. This is largely because those who were intrusted with their learlership were specially fitted, by nature as well as by experience and training, for the undertaking. The parties have usually been made up of a few carefully chosen men, and the physical work and discomforts, as well as hardships, have been shared by leaders and men alike. In connection with the topographic surveys geologic investigations have gone hand in hand; in some instances somewhat detailed studies having been undertaken, while in others the work was purely of a preliminary character (see fig. 3).

The topographic and geologic mapping carried on in various parts of Alaska since the organization of systematic surveys has resulted in the completion of a preliminary map of the Copper River basin and of the Seward Peninsula. A considerable area has also been surveyed in the region lying between the Yukon and the Tanana. A more detailed map of a part of the Juneau mining district has been finished, which is to serve as the basis for geologic studies during the coming season.

Besides the geologic work already mentioned, it is planned to make a reconnaissance of the oil fields of the Pacific coast belt of Alaska, and to study the placer fields of both the Tanana-Yukon district and the Seward Peninsula. In addition to this economic work steps have been taken to make a detailed examination of some of the Tertiary and Mesozoic beds exposed along the Yukon.

Subsequent to the work done in collaboration with members of the Geological Survey in 1898, the Army continued to send out expeditions. In the following year some more or less detailed surveys were carried on in connection with constructing the military trail across the Chugach Mountains from Valdez. These operations, as well as some minor explorations, were carried on under direction of Captain Abercrombie. Oscar Rohn, a civilian employee of Abercrombie's party, with one companion, made a daring journey, in which he crossed the Wrangell Mountains to Tanana waters and then returned to Copper River, making a sketch map as well as geologic observations. 
Another party, provided with horses and a large river steamer, was sent to Cook Inlet under command of Captain Glenn. The most notable contribution of this expedition to geographic knowledge of Alaska was Lieut. Joseph S. Herron's exploration in the upper Kuskokwim basin. Following the general route previously traversed by Spurr and Post, Herron crossed the Alaska Range and entered the great lowland which lies to the northwest. Here considerable time was lost by a search for natives to act as guides, during which the early frosts killed the grass and the pack horses had to be abandoned. At length, with the aid of Indian guides, Herron's party reached the Yukon in the early winter. C. E. Griffith, a

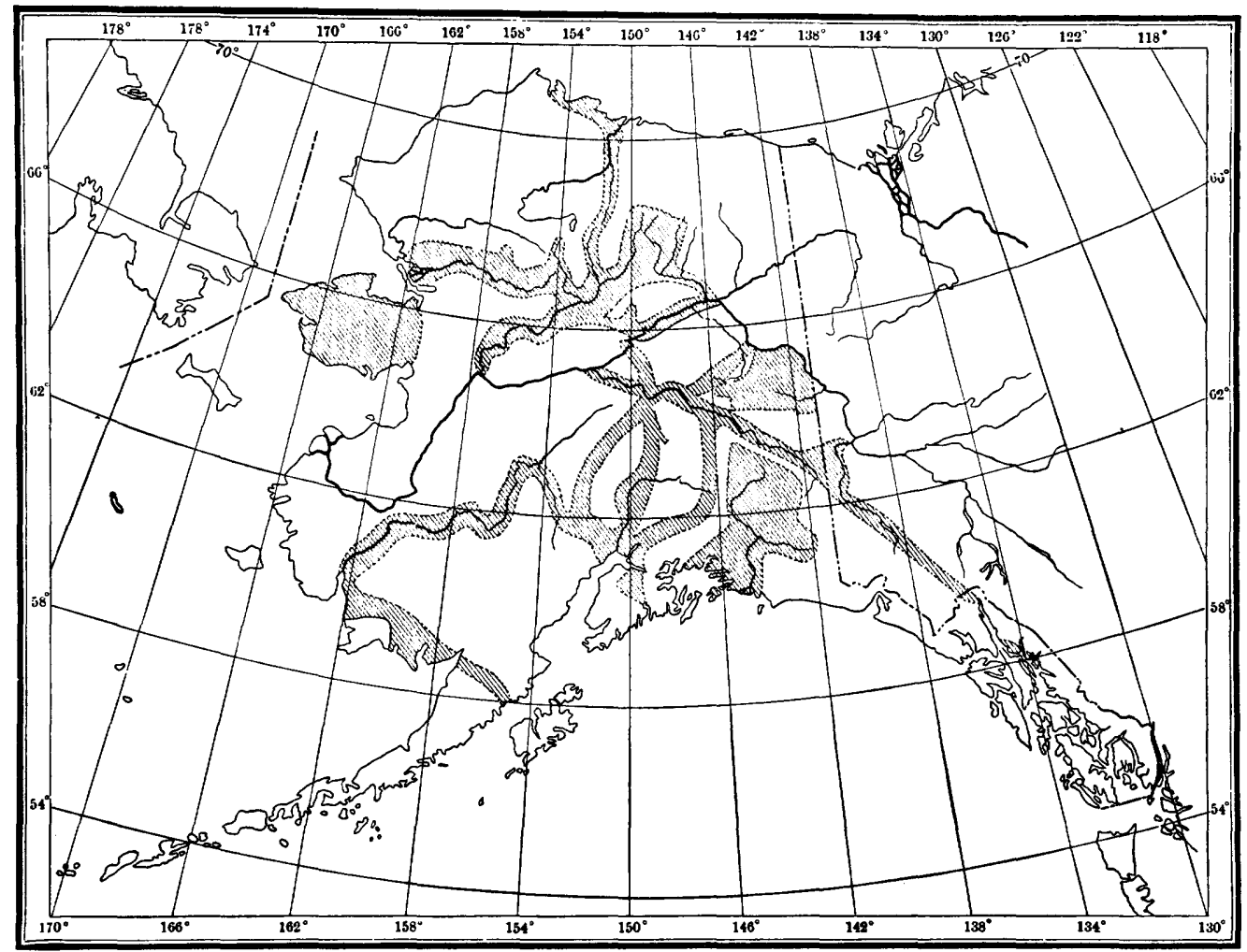

FIa. 3.-Map showing areas surveyed and explored by United States Geological Survey, 1898 to 1903.

topographer of Glenn's command, led a small party from Knik Arm, Cook Inlet, to Eagle, on the Yukon. His route lay partly through the region previously explored by Glenn and Mendenhall, and partly over the well-traveled trail which leads from Valdez to Eagle. George W. Van Schoonhoven, also of Glenn's party, attempted, with a full equipment of horses, to reach the Tanana from Cook Inlet. He first followed the route surveyed by Eldridge and Muldrow in the previous year, but turned back at the Cantwell, reporting the route impassable. In this he was mistaken, for Brooks and Reaburn in 1902 crossed the Cantwell where he turned back, and continued through to the Tanana without serious difficulty. 
During the past two years the Signal Corps of the Army has been pushing the work of constructing telegraph lines, and as a result has connected by wire the most important ${ }^{a}$ points, both inland and on the coast. Reconnaissance surveys have to a certain extent been carried on subservient and preliminary to the construction of the telegraph lines.

\section{CONCLUSION.}

Over a century and a half has elapsed since Bering and Chirikof first sighted the mainland of what is now known as Alaska, and during this time geographical discoveries have been steadily going on within its borders. First came the Russian trader, who in the course of his marauding voyage made his way step by step along the Aleutian Islands to the mainland. Then Cook and Vancouver and other navigators carried on systematic surveys of its shore line. With the organization of the Russian-American Company, in 1799, a new epoch of permanent settlements and slight but important explorations was introduced, which continued until the transfer of Alaska to the United States. During this time the English contributed much toward a knowledge of Arctic Alaska through the surveys made by their Franklin relief expeditions. Mackenzie's famous journeys across the continent to the Arctic Ocean pointed out the way to lucrative fur trade to the English, and brought them to Alaska from the east. Their explorations on the upper Yukon were linked with those of the Russians below by the journey of Kennicott, Dall, and their associates of the telegraph survey.

After Alaska became a United States possession there was a lull in explorations within its borders, though the Coast Survey began to chart the coast line. Except for Raymond's trip up the Yukon and the efforts of Petrof and of fur traders and prospectors no attempt was made at an extension of geographic knowledge in the interior until Schwatka made his trip down the Lewes and Yukon. This was followed by the less generally known though no less important explorations in the northern part by officers of the Navy, the Revenue-Marine Service, and the Coast Survey. Since Alaska attracted public notice through its placer gold resources important and extensive surveys and explorations have been carried on by the Geological Survey.

Alaskan surveys and explorations have never been and never will be easy. Throughout its history the geographic investigation has been a tale of hardship and suffering and not infrequently of death. Let those who are not personally familiar with the character of the difficulties not judge it too harshly. If the results have not always been commensurate with the expenditure of money, time, and even of human life, it should be remembered that the conditions of travel in the past have not been so favorable to the explorer as in some of the more temperate regions. The task is not yet complete. Reconnaissance surveys have been effected in but one-fifth of the territory, leaving large areas which are still practically unexplored.

$a$ Nome, the Yukon, Tanana, and Copper River valleys are now counected with Dawson and with Valdez by telegraph. Daweon has outside telegraph connections through Canadian territory with the United States and to the coast at Skagway, Alaska. Skagway, Seward, and Valdez, all on the Pacific coast, are connected by cable with Seattle. 



\section{Appendix E}

\section{SURVEYING AND MAPPING IN ALASKA \\ by \\ Gerald FitzGerald}

\section{INTRODUCTION}

As the story of surveying and mapping in Alaska has never been written before, the following account is based on fragmentary published and unpublished material, principally from the files of the various Federal departments. Alfred H. Brooks, Chief Alaskan Geologist of the U. S. Geological Survey, in Professional Paper No. 45, published in 1906, summarized the early exploration of Alaska and described the first systematic topographic mapping undertaken by the Survey between 1895 and 1902 . Other publications on the subject are for the most part confined to reports of the Federal Government or to popular magazine articles.

Hydrographic, geodetic, and topographic surveying in Alaska has been carried on chlefly by three or four Federal agencies since the turn of the century. The writer has abstracted and compiled information from various official reports for the preparation of this sketch for the period from 1900 to the present time. It would be impossible in a single article to describe completely even the major surveying and mapping expeditions conducted by the Federal Government. An attempt has been made, therefore, to select only those considered of outstanding importance or those which have made some real and lasting contribution to the geographic knowledge of the Territory.

Partly because of its remoteness and partly because of the unusually difficult conditions encountered in conducting surveying operations in Alaska, the Territory has been the proving ground for many important developments in the art of

\footnotetext{
1 This paper was originally prepared for the Encyclopedia Arctica.
}

surveying and mapping. Terrestrial photogrammetry was used successfully as early as 1893 by the Canadian Government and the U. S. Coast and Geodetic Survey on the International Boundary Surveys in southeastern Alaska. A panoramic camera was developed by members of the Geological Survey in 1905 and used successfully for many years on topographic mapping of Alaska. The first American trilens aerial mapping camera and transforming printer were developed before World War I by J. W. Bagley and F. H. Moffit, members of the Geological Survey engaged in Alaskan work. The Navy Department, at the request of the Geological Survey, completed aerial photographic coverage of more than 20,000 square miles in southeastern Alaska during the period between the first and second world wars.

During World War II "trimetrogon" mapping was developed, largely by Geological Survey personnel engaged in Alaskan mapping and by members of the Army Air Forces, to meet the urgent need for aeronautical charts of this vast area. Naval photographic squadrons returned to Alaska after the war and rephotographed the area of southeastern Alaska with new precisionmapping cameras. Still more recently the Department of the Air Force accomplished a successful photographic coverage of the principal transportation routes leading into the interior of Alaska. This photography was controlled by "shoran", an electronic method used to determine geographic positions within the area photographed. The airplane, helicopter, truck, and tractor have, to a considerable extent, replaced the canoe, dog team, and pack train, and solved the transportation problems connected with surveying in Alaska. Because of the Territory's recognized strategic position in the modern 


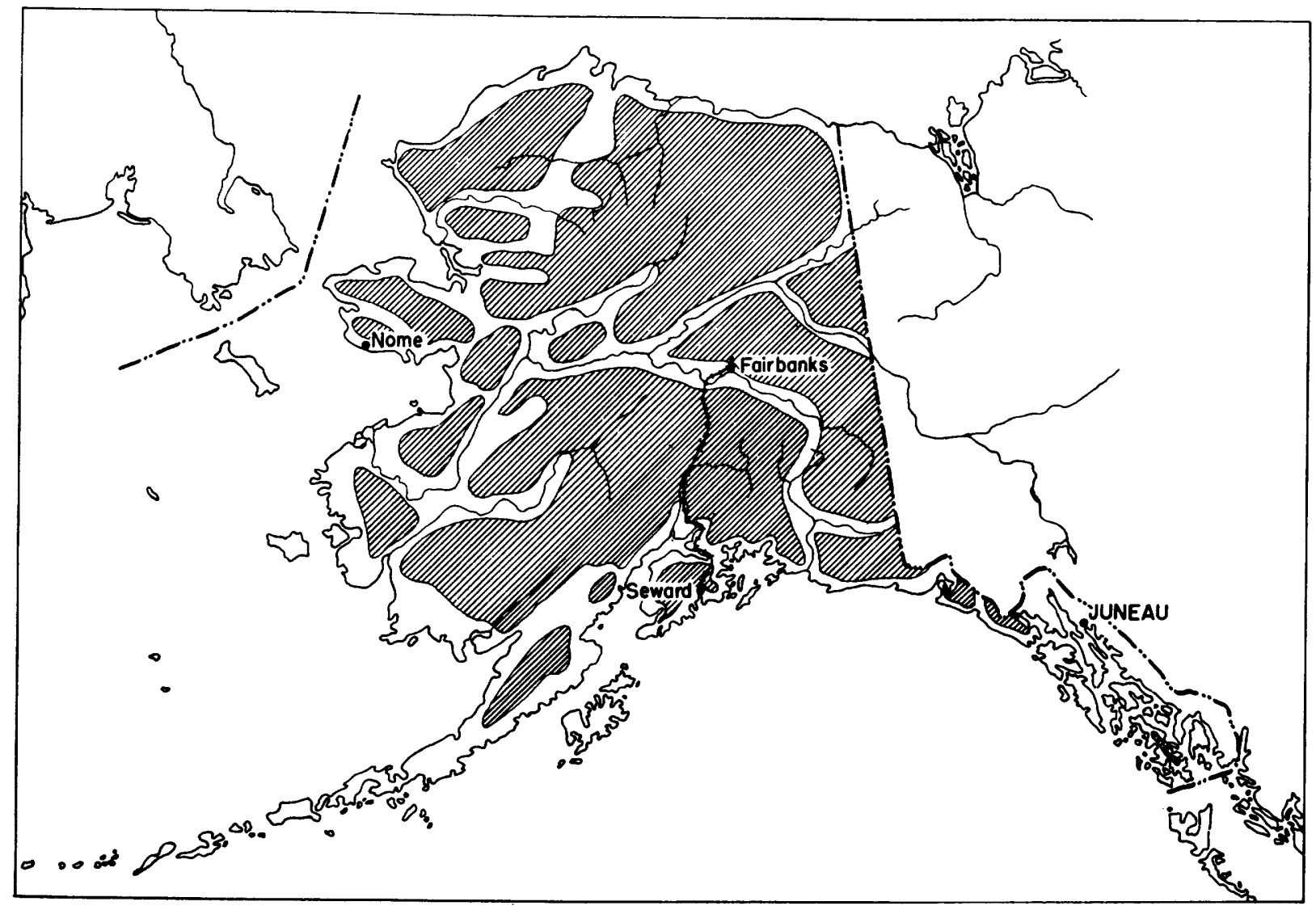

Figure 1. --Unexplored areas in 1895.

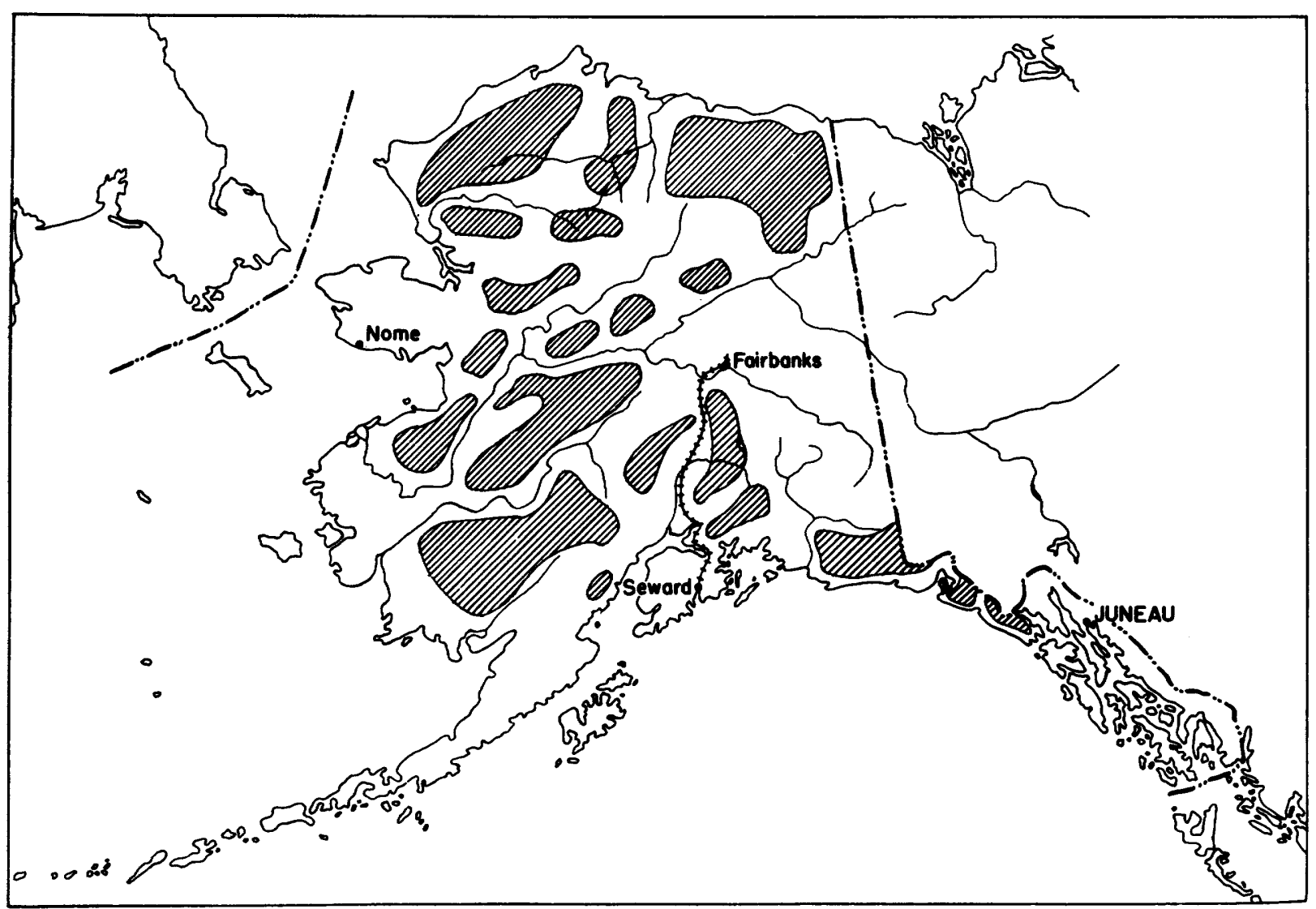

Figure 2. --Unexplored areas in 1905. 


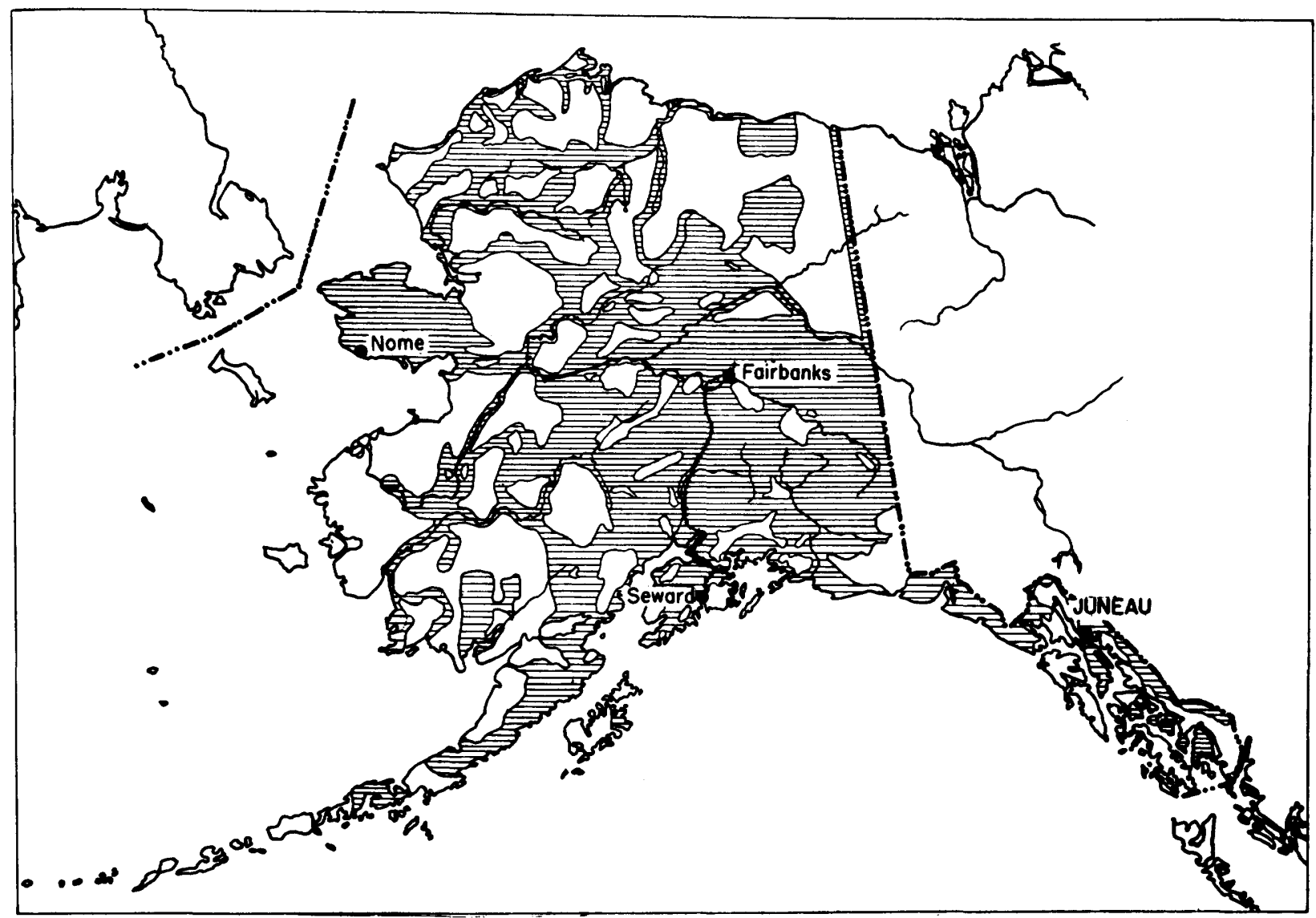

Figure 3. --Exploratory and reconnaissance mapping completed by 1940.

defense plans of the Nation, surveying and mapping activities have greatly increased since World War II.

In order to achieve simplicity of arrangement and to avoid overlapping of narrative, this sketch has been arbitrarily divided into four periods between 1728 and 1950. Each of these divisions represents a significant phase in the history of the exploration, surveying, and mapping of Alaska. (See figs. 1, 2, and 3.)

The Russian occupation was mainly a period of maritime exploration of Alaskan coastal areas by expeditions sent out by the principal nations of the world. Stimulated by the fabulously rich fur trade developed and controlled by the Russians for more than 100 years, expeditions from England, France, Spain, Italy, and Portugal explored and charted in some manner most of Alaska's 26,000-mile coast line before the purchase of Alaska by the United States in 1867.

The second period covers the American occupation from the date of transfer in 1867 to 1895 , and was marked by considerable activity in coastal charting and further exploration. The
U. S. Army sent several parties into the new territory to explore the great river basins and to determine at least an approximate position for the international boundary between Canada and Alaska. The Navy Department and the Coast Guard conducted several important exploratory expeditions along the coast of Alaska and into the Arctic. The Coast and Geodetic Survey began coastal surveying and charting operations immediately after the purchase of Alaska and undertook triangulation and the establishment of astronomical positions for the International Boundary Commission.

The third period marks the beginning of organized and systematic mapping and charting in the vast unfamiliar interior of the new Territory, and for the purpose of this report, includes the 45 years between 1895 and 1940 . The increased activity in surveying and mapping during this period was due principally to the "gold rush" of 1898, which focused national attention on the almost-neglected Territory, and resulted in increased Congressional appropriations for Alaskan work. 
With this renewed interest and with additional funds, the Coast and Geodetic Survey expanded its triangulation arcs and its charting operations of hydrographic conditions along the coast. The Geological Survey was able to send geologic and topographic field parties into many of the remote areas of Alaska. The survey of the International Boundary Commission was completed from Dixon Entrance to Demarcation Point. The General Land Office began field work in Alaska in 1899 to establish a rectangular network of surveys necessary for the administration and disposal of public lands. Many private organizations and Federal agencies contributed materially to the geographic knowledge of the Territory. In this category should be included the work of the National Geographic Society, the Harriman Expedition, the Alaska Road Commission, the Army Air Corps, the Coast Guard, the Biological Survey, the Bureau of Fisheries, and many others.

The fourth period, while embracing only ten years, from 1940 to 1950 , has been the most important in the history of surveying and mapping in Alaska. Defense plans for Alaska and the Pacific coast required modern maps and charts. In order to provide a more accurate framework for detailed surveying and mapping, the Coast and Geodetic Survey greatly increased its geodetic survey operations, as well as its coastal charting program. During World War II the Aeronautical Chart Service of the Air Force prepared small scale aeronautical charts of the entire Territory. The Corps of Engineers mapped, by modern methods, a number of quadrangles in the vicinity of Anchorage, and part of Unalaska Island.

Postwar work involved the preparation of military maps of strategic areas in western Alaska. During this ten-year period the Geological Survey compiled trimetrogon photographs into maps and charts for the Aeronautical Chart Service, covering 80 percent of the area of the Territory, and expanded its own standard quadrangle-mapping program to include extensive areas in southeastern, central, and northern Alaska. To further the latter program the Department of the Navy cooperated by photographing all of southeastern Alaska, extensive areas in northern Alaska, Seward Peninsula, and
Kodiak Island. Photographic units of the Air Force, in addition to providing trimetrogon coverage of nearly all of Alaska, completed shoran-controlled photography for nearly 30,000 square miles in central Alaska. The Bureau of Land Management and the Forest Service each made some contribution to the surveying and mapping of Alaska's 589, 870 square miles.

The following account of these four periods, outlined briefly in the preceding pages, presents a fairly comprehensive picture of the major surveying and mapping activities in Alaska for the past 200 years.

\section{RUSSIAN OCCUPATION (1728-1867)}

Although little information was available with which to compile a map of Alaska at the time the United States purchased the Territory from Russia in 1867, a brief review of early explorations is necessary to evaluate properly the slow progress made in surveying and mapping following the American acquisition.

Beginning with the voyages of Vitus Bering in 1728 and 1729, Russian exploration of Alaska was principally from the west, across Siberia and the Bering Sea. Navigators and explorers of several nations approached Alaska from the south, across the Gulf of Alaska or through the meandering fiords of southeastern Alaska. These early navigators included the English, who also entered Alaska from the east through the Mackenzie River Valley.

Vitus Bering, a captain in the Russian Navy, was sent by Peter the Great to determine the extent of land east of Siberia. His voyages were made in the period between 1728 and 1741, and, while not greatly productive, they established beyond any doubt that a great land mass existed east of Siberia, connected or nearly connected with Russia by a long chain of islands. The reports of Bering's voyages stimulated the development of the fur trade on the Aleutian Islands. As the supply there became depleted, the fur trade spread gradually to the mainland of Alaska. One of the principal headquarters for this trade was established at Kodiak in 1783 
under Alexander Baranof, general manager of the Russian-American Company. A grant from the Russian Government placed Alaska in the hands of this company for a perlod of 60 years.

While the Russians were developing the valuable fur trade of the Aleutian Islands, the Alaska Peninsula, and western Alaska, the Spanish sent several expeditions to explore southeastern Alaska. During this same period, Captain James Cook and Captain George Vancouver also salled north to explore southern Alaska. Commander Jean Francois LaPerouse was sent by the French to explore southeastern Alaska in 1786, but he covered much of the area seen by earlier Spanish and English explorers. England, in search of the Northwest Passage, sent several wellequipped expeditions farther north. Captain Cook made his famous voyage' into the Arctic Ocean in 1778 and Captain F. W. Beechey charted the north coast of Alaska to Point Barrow in 1828. Vancouver, who had sailed with Cook in 1778, returned to Alaska in 1791 and spent much time preparing a chart of the complicated shorelines and fiords of southeastern Alaska.

In the meantime, the Russians under Baranof had expanded in western, southern, and southeastern Alaska where, in addition to the earlier posts in the Aleutian Islands, the Russians established settlements on Cook Inlet, Sitka Sound, and Prince William Sound. The whole of known Alaska was now in the hands of the Russians. This was formally recognized by England in a treaty signed with Russia in 1825. After this time, exploratory expeditions of other nations to Alaska were limited.

Baranof, who was not interested in exploration, was removed and Russian naval officers placed in charge of the Russian-American colony. Sc1entific work under the Navy was given more support and considerable progress was made in coastal exploration. Captain Michael Tebenkof of the Russian Navy prepared an atlas of the northwestern coast of America in which he compiled the results of all previous explorations. This atlas is considered the most important contribution to the geography of Alaska made during the Russian occupation.
Before 1826 the Russians had confined most of their activities to the coastal areas of Alaska, but as interest grew in the possibility of extending the fur trade into the interior, expeditions were authorized to continue surveys along the northern coast and as far inland as possible. The Bristol Bay and Kuskokwim River reglons were visited in 1818 and 1832, and the Susitna River Basin explored by a Russian group in 1834. The Yukon River was reached from the portage of St. Michael on Norton Bay by another smail party, which then portaged to the Kuskokwim River.

One of the most important of the Russian inland explorations was made by Lieutenant Zagoskin of the Imperial Navy in 1842-1843. This party ascended the Yukon River as far as the mouth of the Tanana River, and also explored the lower stretches of the Koyukuk River. On his return Zagoskin traversed the Innoko River, a tributary of the lower Yukon, and then portaged east to the Kuskokwim River.

While the Russian treaty of 1825 with England considerably curtalled foreign exploration, particularly of southeastern and southern Alaska, English navigators continued their explorations of the northwest coast. Alexander Mackenzie had explored the great river that now bears his name to the Arctic coast from the thouth of the Mackenzie westward. Captain Beechey, cooperating with Franklin, charted the southern coast of Seward Peninsula to Cape Prince of Wales and added much information to the earlier surveys of Kotzebue Sound. In 1834 the Hudson's Bay Company made several attempts to establish itself in southeastern Alaska, finally securing a 10-year lease from the Russians in 1837. In the meantime, this company had established posts on the upper Yukon River and was rapidly controlling the fur trade of that area.

In the period between 1843 and 1853, the British Government sent out several expeditions to bring relief to the 11 -fated expedition of Sir John Franklin on the Arctic coast. These expeditions resulted in maps and charts of the Arctic that have been superseded only by aerial photography taken during World War II. 
The Western Union Telegraph Company in 1863 undertook preliminary explorations to establish a telegraph route from the west coast of the United States through British Columbia and Alaska to the Bering Strait, where a cable connection with a trans-Siberian line was planned to establish communications between America and Europe. The exploration work in connection with the establishment of this telegraph line contributed much to the knowledge of the interior of Alaska. William H. Dall, one of the leaders of the scientific corps of the expedition, continued his work after the telegraph-survey party was disbanded, and published the results of his investigations in several of the best-known earlier reports on Alaska.

\section{AMERICAN OCCUPATION (1867-95)}

After several years of negotiations, Alaska was purchased from Russia in 1867 for $\$ 7,200,000$. However, for the next 30 years exploration and surveying work were carried on in a small way with little coordination.

During the Russian occupation much of the 26, 000-mile coast line of Alaska had been explored and charted by expeditions of several nations. The most important work, however, was done by the English expeditions under Captain James Cook and the relief expeditions sent to the aid of the Franklin party on the Arctic coast.

The Coast and Geodetic Survey, soon after the transfer of Alaska, began the first system.. atic survey work in the new Territory, and, between 1867 and 1882, compiled and published numerous charts of Alaskan waters. As these charts were based principally on the earlier surveys by English, Russian, French, and Portugese explorers and by the U. S. Navy, much of the early field work was done to control and piece together the fragmentary material already available. The Revenue Service, the Fishing Commission, and the Navy assisted in this work and each contributed in part to the charts and Coast Pilots published by the Coast and Geodetic Survey.

In the summer of 1867 , George Davidson and others made an extensive cruise of Alaskan waters in the Revenue Cutter Lincoln, and as a result prepared cruise charts of Sitka Harbor, Saint Paul Harbor, Kodiak Island, and Captain's Bay on Unalaska Island. The first two Coast Pilots of Alaska were published between 1869 and 1883, based on the work of George Davidson, William H. Dall, and Marcus Baker. A third was prepared by Lieutenant Commander H. E. Nichols, U.S.N. in 1891.

The first continuous survey work by the Coast Survey was started in 1882 when the Steamer Hassler was sent north under the command of Lieutenant Commander H. E. Nichols, U.S.N. and later under Lieutenant Commander A. S. Snow in 1884. The Steamer Patterson was assigned to Alaskan waters in $\overline{1885 \text { under }}$ the command of Lieutenant Commander Richard Clover, U.S.N., and for the next 15 years field work consisted mainly of charting only those channels and harbors used by the Navy and for the very limited commercial shipping.

One of the first inland explorations after the acquisition of Alaska was undertaken by a small party under Captain V. W. Raymond, sent by the Army to Fort Yukon in 1869 to determine the position of the international boundary between Canada and Alaska. As a result of Captain Raymond's astronomical observations at Fort Yukon, the Hudson's Bay Company was forced to move its important Fort Yukon post to a point more than 50 miles up the Porcupine River, where it remained for 15 years. In 1889 the post was relocated farther up the Porcupine, at Rampart House, which was located on the 141st meridian, or the Alaska-Canada boundary.

About 1880 prospectors began to enter Alaska and the Yukon Territories. This activity renewed interest in the geography of southeastern Alaska and the territory between the coast and the headwaters of the Yukon River. Glacier Bay, one of the outstanding scenic areas in Alaska, was explored vy John Muir and the Reverend S. Hall Young in 1879. Ivan Petrof, a census agent, in 1880 stated in his report that Alaska needed "a gradual but systematic exploration of the interior, and an immediate survey of the coast and harbors of the region now constantly frequented by trading and fishing vessels, in order to prevent the alarmingly 
frequent occurrences of wrecks upon unknown rocks and shoals." Petrof, a resident of Alaska, spent two years traveling along the southern coast of the Territory and on the lower Yukon and Kuskokwim Rivers. His map of Alaska, published with the Tenth Census report, was one of the best general maps of the Territory that had been compiled at that time.

In 1883 Lieutenant Frederick Schwatka, accompanied by Charles W. Homan, followed the prospectors' trail from the coast over Chilkoot Pass and descended the Lewes River through Lake Laberge down the main Yukon River through Canada and Alaska to its mouth at Norton Sound. Homan mapped the entire route by sketch traverses and latitude observations. This was the first actual survey of the Yukon River.

The U. S. Signal Service established a meteorological and magnetic station in 1881 at Point Barrow where observations were made for latitude and longitude. During this same year a German geographer, Dr. Arthur Krause visited southeastern Alaska and the headwaters of the Yukon River and prepared a map of the area.

During the period between 1883 and 1886 several exploratory expeditions of note were made in Alaska by officers of the Army and Navy. In 1883 Lieutenant George M. Stoney of the Navy Department explored parts of Kotzebue Sound at the mouth of the Kobuk River. As a result of this work the Department became more interested in northern exploration, and Lieutenant Stoney was returned to Alaska the next year to explore the Kobuk River. In 1886 he established headquarters on the upper Kobuk River and from this base explored the headwaters of the Noatak and Koyukuk Rivers. One of his officers, Ensign W. L. Howard, led a party of four men from the Noatak River northward through what now is known as Howard Pass, down the Etivuluk River to the Colville River, and to a point near the present site of Umiat. From this spot he portaged to the headwaters of the Chipp River, and arrived at Point Barrow in midsummer. He thus became the first white man to cross Arctic Alaska. The results of the Stoney expedition were sketch maps and some instrumental surveys of parts of the Kobuk Valley, Selawik Lake, the
Colville, the upper Noatak River, and the Alatna, a tributary of the Koyukuk River.

In 1884 a U. S. Army expedition, under the command of Lieutenant W. R. Abercrombie, was ordered to make an exploration of the Copper River area. This expedition was not entirely successful, and was undertaken again the following year by Lieutenant Henry T. Allen, who landed near the mouth of the Copper River in March 1885, and ascended that stream for several hundred miles. A portage was made through Suslota Pass to the Tanana River where he obtained a boat and finally reached the mouth of the river near the end of June. Allen then portaged to the Koyukuk River and reached a point near the mouth of the Melozi River. He next explored the Koyukuk River from its headwaters to its confluence with the Yukon River. Continuing down the Yukon River, he crossed the Kaltag portage to St. Michael on Norton Sound. Lieutenant Allen's journey is generally conceded to be one of the most outstanding exploratory trips ever made in the Territory of Alaska. Under extremely trying conditions, subsisting almost entirely on the country, he nevertheless made a careful record of his entire journey, and from his observations and sketches was able to compile an exploratory sketch map of the entire area traversed.

During 1884 and 1885 Lieutenant John C. Cantwell and S. B. McLenigan of the U. S. Revenue Cutter Service explored the headwaters of the Kobuk and the lower Noatak and made sketch maps of both these important northern rivers.

Surveys to locate and mark the international boundary between Alaska and Canada were begun in 1888 by the Canadian Government, which started work in southeastern Alaska. In the years 1891 and 1895 the Coast and Geodetic Survey completed triangulation and astronomical work for the geodetic control, and Canadian surveyors introduced photo-topographic surveying for the preparation of boundary maps. During 1889 J. H. Turner and J. E. McGrath had ascended the Yukon River to Fort Yukon where the party separated. Turner continued up the Porcupine to the Alaska-Canada boundary, where he established an astronomical observatory 
and then went north to the Arctlc coast by dog team. McGrath, accompanied by Professor I. C. Russel of the Geological Survey, continued up the Yukon River to a point near Eagle, where he also established an astronomical position for the boundary.

The discovery of gold was largely responsible for the greatly increased interest in Alaska and subsequent inauguration of the international boundary survey, and expansion of the Coast and Geodetic Survey's coastal charting program. In 1898 this increased interest resulted in appropriations to the Geological Survey that permitted the undertaking of a systematic program of geologic and topographic surveys of the interior of Alaska. Appropriations to the Geological Survey continued at a more or less uniform rate for the next 40 years.

\section{SYSTEMATIC MAPPING AND CHARTING IN ALASKA (1895-1940)}

The turn of the century was the beginning of a period in Alaska in which organized coastal surveys were continued at an accelerated pace to provide for water-borne navigation, and topographic maps of the interior at reconnaissance scales were made to keep pace with the development that followed the discovery of gold. Because of the climate and remoteness of Alaska, surveying and mapping were often carried on under extremely difficult conditions. Transportation and supplies, of course, presented the major problems and, owing to the shortness of the field season, the great variation in topography, and other factors, the surveyor and mapper were called upon to devise and develop new and ingenious methods for accomplishing their work. Terrestrial photogrammetry was employed on Alaskan surveys as early as 1893 . The necessity of mapping large areas rapidly on a reconnaissance scale stimulated interest which resulted in the designing of the first Americanmade multiple-lens camera by J. W. Bagley and his associates of the Geological Survey before World War I. It was only natural, therefore, that the Navy Department, under cooperative agreement with the Geological Survey, photographed 20,000 square miles in southeastern Alaska with the multiple-lens Bagley camera in 1926 and 1929.
New and advanced methods and equipment were developed and used by the Coast and Geodetic Survey to prepare both general and detailed navigation charts of the coastal waters and the principal harbors of Alaska. The hand lead was superseded by the wire drag and the sonic depth finder. The Radio Acoustic Ranging, or "R.A.R." permitted more accurate positioning of ships on deep-water offshore sounding, and permitted operations even with land points obscured. Alaska became an ideal proving ground for the development of reconnaissance mapping by photogrammetric methods and it was here, in 1940, that "trimetrogon mapping" was first used.

\section{Work of the Geological Survey (1895-1940)}

$$
\text { 1895-1902 }
$$

Annual appropriations by Congress for the work of the Geological Survey in Alaska, which included topographic mapping, fluctuated widely from $\$ 5,000$ in 1895 to a peak of $\$ 100,000$ during the years 1913 to 1917 . The appropriation for 1940 was $\$ 60,000$. This amount was for all of the Survey's operations in Alaska, and, consequently, less than half of it was available for topographic mapping.

The extent of areas mapped in Alaska by the Geological Survey to January 1940 is shown in the following table:

\begin{tabular}{|c|c|c|}
\hline & $\begin{array}{l}\text { Contour } \\
\text { interval }\end{array}$ & $\begin{array}{l}\text { Square } \\
\text { miles }\end{array}$ \\
\hline $\begin{array}{l}\text { Exploratory mapping on } \\
\text { scale of } 1: 500,000 . \ldots\end{array}$ & 200 feet & 8,952 \\
\hline $\begin{array}{l}\text { on scale of } 1: 250,000 . . \\
\text { Planimetric mapping on }\end{array}$ & 200 feet & 185,586 \\
\hline $\begin{array}{l}\text { reconnaissance scale .. } \\
\text { Detalled mapping, com- } \\
\text { monly on scale of }\end{array}$ & None & 10,894 \\
\hline $\begin{array}{r}1: 62,500 \ldots \ldots \ldots \\
\text { Total } \ldots \ldots\end{array}$ & 50 feet & $\frac{4,552}{09,984}$ \\
\hline
\end{tabular}

Members of the Geological Survey were sent to Alaska prior to 1895 in connection with scientific expeditions. Professor I. C. Russel was assigmed to a Coast and Geodetic Survey party 
in 1889 under J. E. McGrath who was ordered to the upper Yukon River to determine by astronomical observations the position of the boundary line between Alaska and Canada. In 1891, Dr. C. Willard Hayes of the Survey accompanied Lieutenant Frederick Schwatka to the headwaters of the Yukon River, via Taku River and Teslin Lake. This party portaged from Fort Selkirk on the Yukon to the White River which they ascended to Skolal Pass and, by portaging again to the Nizina River, they finally descended the Copper River. Dr. Hayes prepared an excellent exploratory map of the trip from his notes and observations.

Prospectors for gold who entered Alaska through southeastern Alaska and from the Yukon Territory during the early 90's demanded information about the interior, and Congress in 1895 appropriated $\$ 5,000$ to the Geological Survey for the "Investigation of the mineral resources of Alaska." Three Survey geologists, G. F. Becker, William H. Dall, and J. E. Spurr, were sent north to study the coal and gold deposits. Spurr returned to the Klondike in 1898 when gold was discovered there. New discoveries in the Yukon Territory and the great influx of prospectors to Alaska caused Congress to increase appropriations to the Geological Survey for work in Alaska in 1898. From this date organized and systematic topographlc mapping became an integral part of the Geological Survey's Alaskan mineral resources program.

An attempt was made during the first years of this survey work to explore the main river valleys of the interior of Alaska since these were then the principal routes of transportation. In planning the 1898 field season it was decided, therefore, to make exploratory surveys of the Kuskokwim, the Susitna, and the Copper Rivers. One of these expeditions, headed by J. E. Spurr, geologist, with W. S. Post, topographer, arrived at the upper end of Cook Inlet in the spring of 1898. The party ascended the Yentna River, a tributary of the Susitna River, portaged through the Alaska Range to the headwaters of the Kuskokwim River, and descended that great river to its mouth. They then turned eastward and, traveling inland parallel to the coast, finally reached Bristol Bay. Using native skin boats the party crossed the bay and reached Naknek on the Alaska
Peninsula. Continuing overland they at last reached Shelikof Strait and Kodiak Island. This was a remarkable trip considering the great distance traveled, the difficult portages, and the fact that almost the entire route was unexplored. Post prepared the map of the entire route which accompanled Spurr's report.

During this same year the Susitna River was mapped by George $H$. Eldredge and Robert Muldrow, who, with a small party traveling by boat and backpack, reached the Cantwell or Nenana River, a tributary of the Tanana River. They returned to the coast via the Susitna River. Exploratory topographic maps were made of the route of this expedition, which included the first determination of the position and height of the continent's highest mountain, Mt. McKinley, 20, 300 feet above sea level.

A third party in 1898 explored and mapped the Tanana and White Rivers, headwater tributarles of the Yukon. This party was under the charge of Alfred H. Brooks and W. J. Peters. It made exploratory surveys of about 10,000 square miles. In addition, E. C. Barnard made a survey of about 2,000 square mlles of the Forty-Mile River basin, a tributary of the Tanana.

The War Department sent two expeditions into Alaska during 1898. The first, under Captain Edwin F. Glenn, which left the coast at Cook Inlet, traversed the Matanuska Valley, crossed the Copper River Plateau, and drifted down the Delta River to the Tanana River. W. C. Mendenhall, of the Geological Survey, accompanied Captain Glenn and prepared an exploratory traverse map of the journey.

The second expedition, under Captain W. R. Abercrombie, landed at Valdez and with the aid of pack horses traveled inland to the Copper River valley by the Valdez Glacier route. F. C. Schrader of the Geological Survey was attached to this expedition and conducted both geologic and exploratory surveys of the lower Copper River basin. The result of the work of 1898 was exploratory surveys of about 3,000 square miles based on instrumental traverses and, in addition, more accurate reconnaissance maps of approximately 2,000 square miles. 
The experiences of the 1898 parties set a pattern that was to be followed for a great many years in the conducting of exploratory and reconnaissance surveys in Alaska by the Geological Survey. In the interest of economy most expeditions of the Survey consisted of a combined topographic and geologic party, with the man senior in length of experience generally in command. Additional members of the party were recorders, boatmen, cooks, horse packers, and dog-mushers.

For river work, Peterborough-type canoes were often used for transportation. These light cedar-strip canoes could carry a load of onehalf ton and were, without much difficulty, portaged many miles by the parties. Pack horses used for cross-country work were usually purchased in the western United States and shipped north with the field parties in the spring. "Wintering" a pack train in Alaska was often attempted in the interest of economy, but was not always successful. Dog teams were purchased in Alaska. On many of the expeditions dogs were used to haul sleds in winter and for packing during the summer months.

Camp equipment consisted of small, light mosquito-proof tents, sleeping bags, cooking utensils, axes, guns, and ammunition. The equipment and feed for a party of 6 men, for a period of 4 months, would generally weigh between 1,800 and 2,000 pounds. Great care was used in outfitting a survey party for work in Alaska, either for winter or summer work. In addition to food, tents, beds, and cooking gear, medical supplies and carefully selected personal clothing were of importance, since most of the parties were "on their own" during the fleld season. During recent years, however, the airplane, helicopter, and radio have greatly changed all this.

Topographic work was carried on by standard Geological Survey plane-table methods accepted for reconnaissance mapping. The equipment consisted of a plane table, telescopic alidade, and a light mountain-transit theodolite. A micrometer eyepiece attachment for the alidade was often used in determining traverse distances. Graphic plane-table triangulation, checked by latitude and azimuth observations, was generally used in conducting reconnaissance plane-table surveys, which in most cases originated from bases measured at the starting point of field work. (See fig. 4.) Elevations at the inttial point were sometimes determined by aneroid barometers and carried throughout the survey by vertical angles. Special insulation was used on instruments where work in sub-zero weather was required, and most of the plane-table work was done on sheets of celluloid or painted zinc to prevent damage by rain or snow.

Each of the early topographic parties was issued the following instructions: "An attempt will be made to carry a continuous instrumental survey line over the whole route traversed, starting from a position in latitude and longitude at sea level as nearly as may be determined and closing in the same way. The routes traversed will be critically inspected with a view to ascertaining the most practicable location for trails, wagon roads, or railroads; the character and extent of the timber will be noted and the rivers or streams will be examined as to the possibilities of navigation and the height of falls or rapids; and the rise and fall of tides will be reported." In general, the field scale for exploratory and reconnaissance surveys was $1: 180,000$ or about 3 miles to the inch, with a 200-foot contour interval.

In 1899 two major survey expeditions were outfitted for Alaska. Peters and Brooks continued their previous year's work by extending a survey westward from Lynn Canal along the northern base of the St. Ellas Range to the headwaters of the White and Tanana. Rlvers and thence northward to the Yukon at the FortyMile River. This was a pack-train expedition. During the same year F. C. Schrader, geologist, and T. G. Gerdine, topographer, started work at Fort Yukon. They ascended the very swift Chandalar River, and from its headwaters, portaged about 15 milles to the headwaters of the Koyukuk River, which they followed and mapped to its mouth. Eight thousand five hundred square miles were mapped during 1898.

In 1900, eleven thousand square miles were mapped on a reconnaissance scale in the Copper River basin and on Seward Peninsula by Gerdine, Barnard, and Peters. In 1901 Schrader and 


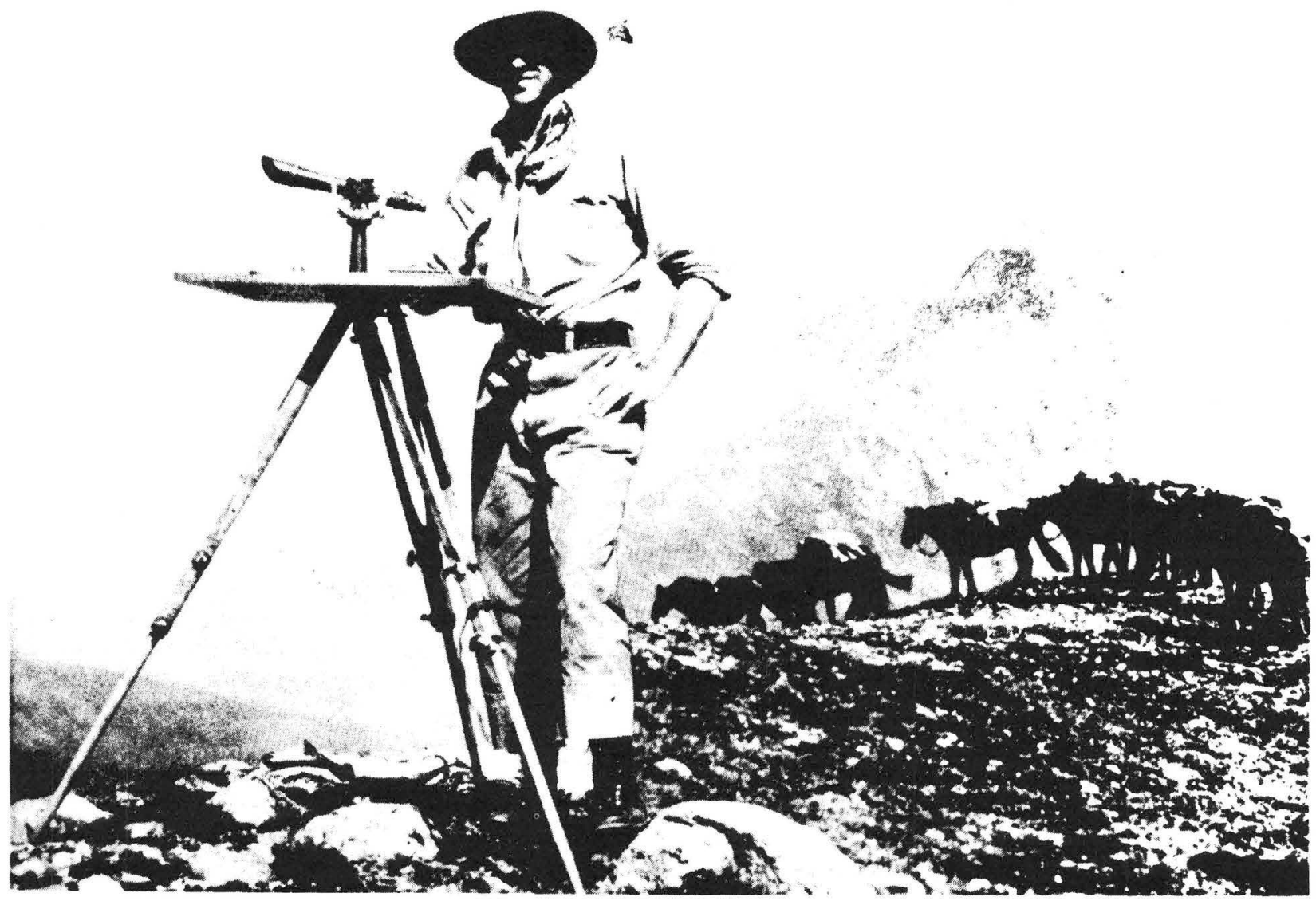

Figure 4. --The plane-table method was employed by the Geological Survey for many years for Alaskan mapping, both reconnaissance and large scale.

Peterș left White Horse in the early spring and arrived at Alatna on the Koyukuk River with dog teams. After the break-up of the ice, they ascended John River, crossed the Anaktuvuk Pass, and descended Anaktuvuk River to the Colville River, which they traversed to its mouth. Here they obtained native skin boats for the coastal trip west to Point Barrow and then south to Cape Lisburne. Alfred $\mathrm{H}$. Brooks considered this to be one of the most notable exploration trips by the Geological Survey to that date.

During this same year W. C. Mendenhall, geologist, and D. L. Rayburn, topographer, started work at the mouth of Dall River on the Yukon and, with the aid of canoes, ascended the Dall and portaged from its headwaters to a headwater tributary of the Koyukuk River. They descended the Koyukuk to the mouth of the Alatna River, which they ascended for nearly 100 miles, making another portage to the headwaters of the Kobuk River, which they followed to its mouth on Kotzebue Sound. Topographic mapping on this trip was started at Fort Yukon, where an elevation of 500 feet was assumed for the river. (This elevation is still used.) A continuous traverse was made down the Yukon River, up the Dall River, down a portion of the Koyukuk River, up the Alatna River, and down the Kobuk River to Kotzebue Sound. During the 1901 season T. G. Gerdine and D. C. Witherspoon made a topographic map of a large part of Seward Peninsula, which was then becoming of great importance because of the gold stampede to Nome, located on the southern side of the Peninsula.

The fleld work for the season of 1902 included an exploratory trip, led by Brooks and Ray. burn, from Cook Inlet through the Alaska Range and along its northwest flank through what is now Mount McKinley National Park to the Nenana River, and from there across the Tanana Rlver in a northwesterly direction to Rampart on the Yukon. During this same year Gerdine and Witherspoon continued topographic mapping in the Copper River basin area, while Peters began a detalled topographic survey of the mining district near Juneau. 


\section{$1902-1910$}

During this period there was a departure from exploratory surveys and a majority of the field parties were requested to prepare reconnaissance maps for publication at a scale of 1:250,000, with a contour interval of 200 feet. At this time a start was also made toward preparing more or less detailed topographic maps of the major mining districts. Although there was some refinement in the execution of field surveys for mapping during this period, the instruments used were not materially changed. J. W. Bagley began experimental work on a panoramic camera that was to be used successfully for many years in Alaska.

From 1902 until 1907, T. G. Gerdine was in general charge of topographic surveys in Alaska, under Alfred H. Brooks, Chief Alaskan Geologist. Gerdine was succeeded by R. H. Sargent in 1907. In addition to Gerdine and Sarcent the following topographers worked in Alaska between 1902 and 1910: J. W. Peters, D. L. Rayburn, D. C. Witherspoon, E. G. Hamilton, J. W. Bagley, C. E. Giffin, R. B. Oliver, G. C. Anderson, J. B. Leavitt, and W. R. Hill.

An exploratory survey covering more than 10,000 square miles was made along the westerm front of the Alaska Range from Cook Inlet to the Yukon. Reconnaissance mapping was carried on in the Yukon-Tanana regions, Seward Peninsula, Kenai Peninsula, Cape Lisburne, Copper River, and the Susitna River Basin. Another party mapped the north flank of the Alaska Range between the Delta River and the Nenana valley. Reconnaissance mapping was also undertaken in the Innoko-Iditarod region, the Koyukuk-Kobuk River valley and the Yakutat-Alsek region. More than 100,000 square miles were mapped for publication at a scale of 1:250,000 during this period. It is estimated that this work cost about $\$ 3$ per square mile.

The detailed mapping of mining districts included the Juneau district, the Kasaan Peninsula in southeastern Alaska, the Kotsina-Chitina on the Copper River, Seward Peninsula near Nome, the Matanuska Coal Fields, the fairbanks special, and The Rampart quadrangle in the interior. These maps were prepared for pubiication at a scale of $1: 62,500$ with contour intervals of 25 , 50 , or 100 feet, and cost about $\$ 30$ per square mile. Between 1902 and 1910 nearly 3,000 square miles were mapped at this scale, which is approximately one mile to the inch.

In 1910 Congress appropriated $\$ 100,000$ for the survey of public lands in Alaska. This subdivision work was carried on in the vicinity of Fairbanks during the field season of 1910 by the Geological Survey under the direction of R. H. Sargent, in cooperation with the General Land Office.

$$
1911-1920
$$

R. H. Sargent supervised the topographic mapping operations of the Geological Survey in Alaska during this 10-year perlod. Other topographers assigned to the work included D. C. Witherspoon, J. W. Bagley, C. E. Giffin, T. P. Pendleton, and C. P. McKinley.

Exploratory surveys for $1: 500,000$ scale publication were continued in northern Alaska on the Alatna and Noatak Rivers and on the Koyukuk River. They covered a total area of 16,500 square miles.

Reconnaissance maps were made on a scale of 1:250,000 of areas in the Copper River valley, Kenai Peninsula, the south flank of the Alaska Range near Broad Pass, along the Richardson Highway from Valdez to Thompson Pass, from Lake Clark across the Kuskowim valley to Iditarod, Tanana valley-White River, the Susitna River, from Ruby on the Yukon south to Iditarod, Prince William Sound, Kantishna district, Goodnews Bay area, and Tuxedni Bay. Twenty different field parties, or an average of two parties a year, carried on this reconnaissance mapping program between 1911 and 1920 , covering a total of 51,000 square miles.

Detalled mapping at a scale of $1: 62,500$ was undertaken for the following areas: Kotsina, Matanuska Coal Field, Willow Creek, Juneau, and Prince William Sound. The total area surveyed on this detailed scale was 1,275 square miles, which included 350 square miles in the vicinity of Juneau mapped for publication on a scale of $1: 24,000$. 
Between 1898 and 1920 the Geological Survey completed the following mapping in Alaska: exploratory surveys at 1:500,000 scale, 51,000 square miles; reconnaissance mapping at 1:250,000 scale, 152,000 square miles; detailed mapping at $1: 24,000$ or $1: 62,500$ scale, 3,700 square miles. Seventy-flve permanent bench marks were established during 500 miles of spirit leveling.

War activity during 1817 and 1918 sharply curtailed mapping operations in Alaska since a majority of the Geological Survey staff were either commisstoned in the Army or assigned to more important war work outside of Alaska.

$$
1921-1930
$$

Alfred H. Brooks died in 1823 and Phillp S. Smith became Chief Alaskan Geologist directing both geologic and topographic work in Alaska.

R. H. Sargent continued to supervise the topographic mapping in Alaska. Other topographers assigned to the work were C. P. McKinley, Gerald FitzGerald, Richard K. Lynt, E. C. Guerin, H. A. Whitaker, O. Lee Wix, K. W. Trimble, J. O. Kilmartin, and R. M. Wilson. In this decade 4,000 square miles of exploratory surveys were made in Arctic Alaska. Reconnalssance mapping of more than 60,000 square miles was completed for such areas as Naval Petroleum Reserve No. 4 in northwestern Alaska, the Alaska Peninsula, Nixon Fork of the Kuskokwim, the Skwentna River, the Porcupine River, the Mount Spurr region of the Alaska Range, Lake Clark-Mulchatna, Goodnews Bay, and southeastern Alaska.

Two hundred and seventy miles of detalled mapping were completed for several widely-separated areas, including Juneau, Wrangell Narrows, the Hyder district, Iniskin Peninsula, and the lower Matanuska valley.

Mapping of Naval Petroleum Reserve No. 4 was started in 1923 in cooperation with the Navy Department and continued through the 1926 field season. Because of the remoteness of the area and the short summer, fleld parties were outfitted at Nenana on the Alaska Railroad during the winter months and used dog teams to transport food and equipment across the Brooks Range to the Colville River drainage on the Arctic slope. From 1924 to 1926 a considerable amount of geologic and topographic mapping was done during the winter and early spring months using dog team transportation. After the "break-up" about the first of June, Peterborough canoes were used on the principal rivers of the region and along the Arctic Coast.

In 1928 an airplane was used for the first time by Geological Survey parties in Alaska to transport personnel and equipment to remote field assignments, thus better utilizing the short fleld season.

In 1926 the Navy Department, in cocperation with and at the request of the Interior Department (Geological Survey), started aerial photographic work in southeastern Alaska. A detail of three amphiblan planes, an airplane tender, a housed-over 110-foot barge, photographic persomel and equipment, and five photographic pilots under the command of Lieutenant Ben H. Wyatt were assigned to the project. The results of this expedition were so successful that the work was continued in 1929 with a second outfit, under the command of Lieutenant Commander A. W. Radford.

This project is considered an important milestone since it marked the first attempt to use aerial photography in Alaska as an aid to mapping. Approxdmately 20,000 square miles were photographed with multiple-lens cameras, covering most of southeastern Alaska. The photographs were used by the Geological Survey to complle planimetric maps of the area. They were also used by the Forest Service, Coast Guard, Coast and Geodetic Survey, and other Federal agencies for special studies and reconnaissance work.

$$
1931-1940
$$

R. H. Sargent continued in charge of Alaskan mapping unt1l 1935 when he became editor of topographic maps for the Geological Survey. Responsibllity for the Alaskan work was turned over to Gerald FitzGerald. John Collins, 
Philip Erickson, C. F. Fuechsel, J. Mark Holmes, George Jensen, R. H. Lyddan, J. E. Mundine, T. W. Ranta, and Vernon Seward were assigned to Alaskan mapping during this 10-year period.

Reconnaissance mapping was continued in southeastern Alaska, and included areas on Admiralty, Chichagof, Baranof, Kupreanof, Kuiu, Prince of Wales, and Revillagigedo Islands. New projects were undertaken in the Copper River valley near the Nabesna district, Slana, Mentasta Pass, and Copper Center, using pack trains for transportation. River boats were used by survey parties in mapping the Goodnews Bay area, Nushagak River, Porcupine River, and the Holitna River. A pack train was used by a party mapping the north base of the Alaska Range east of the Richardson Highway to the Tok River.

Detailed surveys were made of Adak Island in the Aleutians, Chichagof, and Annette Islands in southeastern Alaska, the area near Yakutat on the Gulf of Alaska, and the Goodnews Mining District in western Alaska. Most of this largescale mapping was done by the Geological Survey for the War and Navy Departments, for use in locating sites for possible air bases.

In addition, trilens aerial photography was obtained for the area between Nenana, Lake Minchumina, and a section of the upper Tanana valley in the Tetlin Lake area.

After completion of the 1940 field season the Geological Survey had mapped a total of 210,000 square miles, or about 46 percent of the total area of Alaska. Most of this work was published at a scale of 1:250,000 since much of the exploratory mapping, as well as all of the reconnalssance mapping, was published at this scale. The older exploratory surveys were published at a scale of 1:500,000 in Survey bulletins with the exceptions of the Seward Peninsula sheet and the northwestern Alaska map, which were published as separate maps at the scale of $1: 500,000$.

The detailed maps were at scales of $1: 12,000$, $1: 24,000$, and $1: 31,680$ for special mining maps and $1: 62,500$ for coverage of most of the important mining districts. By 1940 , about 50 separate maps at the above scales had been published by the Geological Survey for general distribution, in addition to several small scale maps which had been complled of the entire Territory. The best known and most popular of these general-purpose maps are Map A, at 1:5,000,000; Map E, at 1:250,000; and Map B (in 2 sheets) at 1:500,000.

\section{Work of the Coast and Geodetic Survey (1895-1940)}

As outlined in a preceding section, the work of the Coast and Geodetic Survey for the first twenty-odd years of the American occupation consisted chlefly of revising and completing much earlier surveys of Alaska in order to prcvide coastal charts so urgently needed during this period of development. However, with the preliminary work on the international boundary undertaken in cooperation with Canada, and with increased charting and geodetic control activity as a result of the discovery of gold, the work of the Coast Survey was greatly accelerated during the nineties. From that time on, increased congressional appropriations made possible a continued program of new charting and refinement of earlier charts and coast Pilots, as well as the expansion of a control network.

Among the early vessels used to perform this new work was the Steamer Patterson which saw service in Alaska from Dixon's Entrance to Norton Sound between 1885 and 1904, and was commanded by Lieutenant Commanders H. E. Nichols, C. M. Thomas, W. S. Moore, E. K. Moore, and Mr. J. F. Pratt. Under the command of Pratt, the Patterson (see fig. 5) was used in making surveys between 1899 and 1904 , in Norton Sound off Nunivak and St. Lawrence Islands, and at other points in the Bering Sea and in the Aleutian Islands. During this period, Pratt also conducted triangulation and hydrographic and topographic surveys in southeastern Alaska and along the north shore of the Gulf of Alaska.

In 1897, triangulation and topographic and astronomical surveys were made of the Pribilof Islands by W. W. Diffield. As a result of these detailed surveys, the Coast Survey published charts at a scale of $1: 20,000$, with a 
contour interval of 20 feet, and at a scale of $1: 2,000$, with a contour interval of 10 feet.

The Survey Ship Pathfinder was built in 1898 for Alaskan duty and was assigned to survey work in western Alaska during 1900 and 1901 under the command of J. J. Gilbert. In 1940, the name of this vessel was changed to the Research and should not be confused with the new Pathfinder.

Hydrographic surveys of Prince William Sound, areas in the Aleutian Islands, and southeastern Alaska were made by Ferdinand Wesdahl, in command of the Coast Survey Steamer McArthur during the field seasons of 1900, 1901, and 1902 .

H. P. Ritter was in charge of a triangulation and hydrographic survey party which worked in the Copper River delta area and in the eastern portion of Prince William Sound during the field seasons from 1898 to 1903.

From 1899 to 1905 the Steamer Gedney, under the command of E. F. Dickins, was engaged in various surveying operations in southeastern Alaskan waters. This work included triangulation, hydrography, and topography.

The discovery of gold in Alaska and the rush to the Klondike region in 1897 created new interest in the long-neglected Territory of Alaska, and the Coast Survey, like the Geological Survey, was given increased appropriations with which to carry on and expand its Alaskan work.

From 1900 until 1940 the Coast and Geodetic Survey continued operations in Alaska to provide navigation charts of the Territory's 26,000 miles of coastline. The survey fleet operating during the early part of this period usually numbered six or more vessels, including the Taku, commanded by R. B. Derickson, and later G. T. Rude, operating in Prince William Sound; the Yukon, commanded by C.G. Quillian, and later F.H. Hardy, operating in the vicinity of Kodiak and in Cook Inlet; the old Explorer, commanded by W. C. Dibrell and others, operating in Bristol Bay; and the vessels previously mentioned.

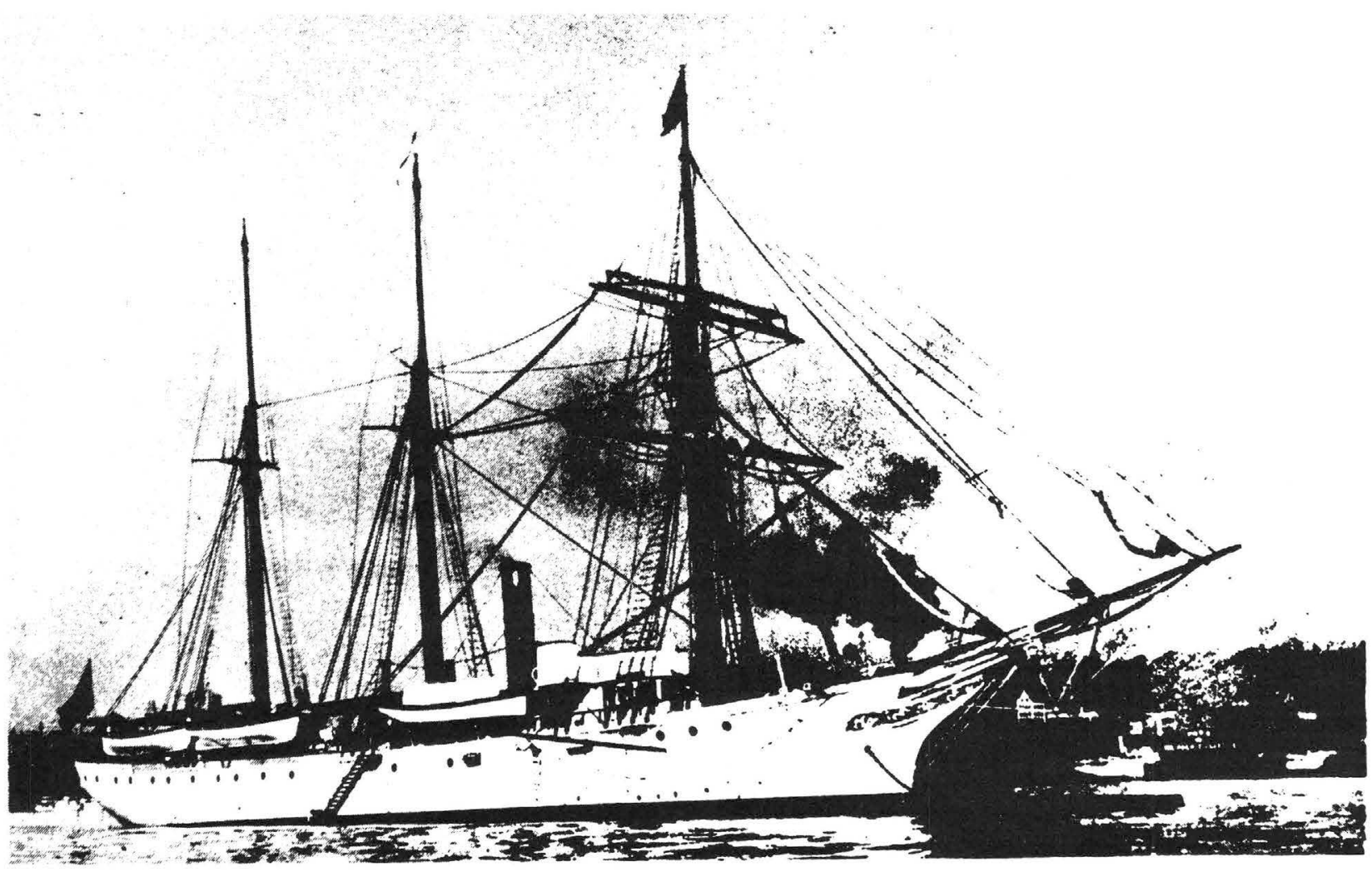

\section{Figure 5. --United States Coast and Geodetic Survey ship Patterson, Seattle, Wash. 1915.}


General small scale charts were prepared for practically all of Alaska's coast line, with special attention given to the complicated channels and small bays of southeastern Alaska from Dixon Entrance to Cape Fairweather. Nautical charts were produced from the surveys of Prince William Sound, Cook Inlet, Bristol Bay, and Norton Sound. Both triangulation and hydrographic surveying were undertaken on Kodiak Island and on the south shore of the Alaska Peninsula.

As travel to Alaska increased, surveys by wire drag were made of the main waterways of southeastern Alaska, and of the principal harbors used by ocean-borne shipping. From these surveys, large scale nautical charts were prepared and published for the rapidly expanding maritime traffic in Alaskan waters. Triangulation was extended in a continuous, unbroken line from Dixon Entrance through southeastern Alaska around the north shore of the Gulf of Alaska into Cook Inlet, Shelikof Strait, and around the south shore of the Alaska Peninsula to Unimak.

Modern survey ships were specially designed and built for the Coast and Geodetic Survey fleet. The new ships included the Surveyor, Explorer, and Pathfinder. Echo-sounding equip ment, developed by the Coast and Geodetic Survey, revolutionized hydrographic surveying, and became standard equipment for all survey ships and launches. To factlitate position fixing of survey ships engaged in offshore hydrography, Radio Acoustic Ranging was developed for use beyond the limit of visibility of shore objects, and for work where the use of buoys for three-point fix control was impracticable or unwarranted.

Following World War I, combined operations were accelerated in Alaska with the survey fleet consisting of the following vessels: the Surveyor, commanded by F. H. Hardy; the Explorer, commanded by $\mathrm{N}$ H. Heck; the Wenonah, commanded by T. J. Maher and J. H. Hawley; the Lydonia, commanded by E. H. Pagenhart; the Discoverer, commanded by H. A. Seran; and the ploneer, commanded by R. R. Lukens. Surveys were extended along the southeast coast, supplementary examinations were made in various parts of the main ship channels, and, in 1926, the preliminary reconnaissance of the Alaska Peninsula was completed.

Before World War II there was little opportunity for the Coast and Geodetic Survey to extend its geodetic operations into the interior of Alaska. Precise levels were now run from the coast to Fairbanks along the Alaska Rallroad and the Richardson Highway. An arc of secondorder triangulation was carried from the head of Cook Inlet along the Alaska Rallroad to the vicinity of Broad Pass. Although reconnaissance work was completed to tie this line to Fairbanks, and eventually to the international boundary, work was not undertaken until after World War II.

The new Explorer and the motor vessel Lester Jones were commissioned in the spring of 1940 and assigned to Aleutian Island surveys. Surveys in the Aleutians by the ships Gulde, Discoverer, and Pioneer were interrupted when the vessels were transferred to the Navy early in World War II.

The early published charts of the Coast and Geodetic Survey, like the topographic maps of the Geological Survey, were rapidly compiled to meet urgent demands for maps and charts required in the development of the new Territory. Most of these exploratory reconnaissance charts either have been replaced or are to be replaced by modern up-to-date charts based on more accurate survey work. The strategic position of Alaska during the last war strongly emphasized the need for better maps and charts.

\section{The International Boundary Survey}

The generalized boundary definitions used in the Convention of 1825 between Great Britain and Russia had resulted in much confusion, and finally caused a serious controversy between Great Britain and the United States after the purchase of the Territory from Russia. At the time of the "gold rush" the location of the boundary line between southeastern Alaska and Canada became the subject of an international dispute that was finally settled by a Tribunal in London in 1903. In accordance with the 
decision of this Tribunal the boundary was to be surveyed and monumented between Dixon Entrance and Mount St. Elias. A large amount of preliminary work had been accomplished along this portion of the boundary in the years 1891 to 1895 by both the Canadian and the United States Governments. Field parties of the Coast and Geodetic Survey did triangulation and astronomical work along the inlets and up the rivers, and the Canadian Survey used terrestrial photogrammetry in the preparation of preliminary maps of the area between the coast and the vicinity of the boundary.

The demarcation of this part of the boundary called for by the Tribunal of 1903 was undertaken during the years from 1904 to 1914, and was under the direction of two commissioners, Dr. O. H. Tittmann, Superintendent of the Coast and Geodetic Survey, for the United States, and Dr. W. H. King, Chief Astronomer of Canada, for the Canadian Government.

During the period of actual survey each country had an average of two field parties working independently to determine the geographic positions of principal peaks along the boundary, and to complete topographic maps along the boundary line. A 20-foot vista was cleared through all timber across the river valleys and on the mountain sides; this slash is still visible along the greater part of the line. Permanent monuments were established to mark the line in the valleys and on those mountain tops that were accessible. The total length of the boundary line was approximately 900 miles, of which about 700 miles was surveyed on land and approximately 200 miles across the water.

The Boundary Commission published 11 topographic maps, Nos. 3 to 13 , covering the section of the boundary from Portland Canal to Mount St. Elias. Sheets Nos. 1 and 2, which cover the area of Dixon Entrance and most of Portland Canal, have finally been completed, and are ready for printing. All the topographic maps are on a scale of 1:250,000, with a contour interval of 250 feet.

The engineers in charge of field work on the southeastern Alaska boundary were: for the
United States, J. A. Flemer and Fremont Morse of the Coast and Geodetic Survey, and $O$. M. Leland, formerly of the Coast and Geodetic Survey, and later Dean of Engineering of the University of Minnesota; for Canada, C. A. Bigger, D. L.S., and N. J. Ogilvie, D. L.S., later Director of the Geodetic Survey of Canada, and Boundary Commissioner.

The boundary line from Mount St. Elias to the Arctic Ocean, along the 141st meridian, became the subject of considerable interest after the Klondike gold rush in 1898, although positions had been established for the $l$ ine at the Yukon River crossing and on the Porcupine River ten years earlier. In 1887 William Ogilvie of the Canadian Survey carried a micrometer traverse from the head of Lynn Canal in southeastern Alaska down the Yukon to the vicinity of the boundary. There he built an observatory and made astronomical observations for a determination of the 141st meridian. This work was started in September 1887 and completed in March 1888, and the line was marked across the river.

In 1889, J. H. Turner and J. E. McGrath, of the U. S. Coast and Geodetic Survey, arrived at Fort Yukon from St. Michael. Turner ascended the Porcupine to Rampart House on the boundary and established an astronomical station to determine the position of the boundary at that point. During the winter he made a dogteam trip from the Porcupine River to the Arctic Ocean along the 141st meridian. McGrath went to the boundary crossing of the Yukon River and made astronomical observations for the determination of the location of the boundary. The final location of the 141st meridian at the Yukon River was made in 1906 by the use of telegraphic time determination for the differences of longitude, and this result differed but little from those previously made. The observers participating in this work were Edwin Smith and J. E. MCGrath of the U. S. Coast and Geodetic Survey, and Dr. Otto J. Klotz and F. A. McDiarmid of the Dominion of Canada Observatory.

In 1907 field parties started work on the actual surveying and monumenting of the boundary 
along the 141st meridian. During this survey the United States and Canada conducted joint survey operations and, in the six years between 1907 and 1913, the combined parties accomplished 750 linear miles of triangulation covering an area of nearly 8,000 square miles. The parties also ran 500 miles of leveling and mapped topographically, on a scale of approximately 1 mile to the inch, 3, 700 square miles along the boundary limits. In addition, 2,500 square miles of rugged, mountainous terrain was mapped by phototopographic methods. Two hundred permanent monuments were on the boundary line between Mount St. Elias and Demarcation Point on the Arctic Ocean. Topographic maps of this part of the boundary were published in atlas form, on sheets 1 to 38 , at a scale of $1: 62,500$, with a contour interval of 100 feet.

The engineers in charge of the work on the 141st meridian were Thomas Riggs, later Governor of Alaska and Boundary Commissioner, for the United States; and J. D. Craig, D. L.S., who was later Surveyor General of Canada and Boundary Commissioner.

The General Land Office in Alaska (1899-1940)

The office of Surveyor General for the District of Alaska was created by the Act of July 24, 1897. The first man appointed to this post was Wm. L. Distin. His office was first located at Sitka, but was moved to Juneau in 1907.

An Act of March 3, 1899, made provision for the beginning of a rectangular system of surveys in Alaska. The first contract, for the survey of the Copper River base line and meridian, was dated March 22, 1904, but not executed until 1905. On August 11, 1914 John P. Walker was appointed to take charge of surveys in Alaska and directed this work until 1924, except for military service during the first World War. He was succeeded by George A. Parks who remained in charge until his retirement in 1948, except for his period of service as Governor of Alaska from June 15, 1925 to April 19, 1933.

In 1910 Congress appropriated $\$ 100,000$ for subdivision surveys of public lands in Alaska, and the Geological Survey was requested to cooperate in carrying out the program called for under this special appropriation. Work was started on subdivision surveys in the vicinity of Fairbanks during the field season of 1910 by four parties, under the direction of R. H. Sargent of the Geological Survey. Precise astronomical observations for latitude, longitude, and azimuth were made by a member of the Coast and Geodetic Survey at Fairbanks, Tanana, and Copper Center.

Following the passage of the Act of October 20,1914 , to provide for the leasing of coal lands in Alaska, the extension of the rectangular system of cadastral surveys to the Bering River, Matanuska and Nenana coal fields was undertaken. Fifteen field parties were organized for these surveys in 1915. The Bering River surveys near Katalla were based on the Copper River meridian; the Matanuska fields near Knik Arm were surveyed under the Seward base line and meridian; and the Nenana surveys were surveyed under the Falibanks base line and meridian.

In 1916 and subsequent years, the rectangular surveys were extended to include agricultural lands in the Cook Inlet district, the Susitna valley, and other areas adjacent to the Alaska Railroad, Kachemak Bay on the Kenai Peninsula, and the Chilkat valley near Haines.

In this period the townsites of Haines, Douglas, Fairbanks, Eska, and Sitka, as well as additions to the townsites of Seward, Nenana, Fairbanks, Anchorage, and Juneau were surveyed.

By $1922,1,550,000$ acres had been surveyed under the rectangular system. In 1923 and subsequent years these surveys were extended to additional areas on the Kenai Peninsula, the Chulitna coal fields, and the Chignik oil fields on the Alaska Peninsula. During this period, the survey of Mount McKinley National Park was also completed. In all, nearly two and one-half million acres have been surveyed in Alaska by the General Land Office (Bureau of Land Management). 
Other Contributions (1895-1940)

Although most of the mapping, charting, and surveying in Alaska during the period 1885-1840 was accomplished by the U. S. Geological Survey, the Coast and Geodetic Survey, the International Boundary Commission, and the General Land Office, important contributions were made to geographic knowledge of the Territory by other organizations, both governmental and private.

The National Geographic Soclety sponsored a number of expeditions to Alaska during the past 40 years. Among the most important were the Alaska Glacier Investigations, carried out in $1909,1910,1911$, and 1913. Also, several parties were sent to the Alaska Peninsula to study volcanoes. Some mapping was accomplished on each of these expeditions. The Soclety also published the results of a number of expeditions to Alaska sponsored by various other organizations, as well as work prepared by individuals on the subjects of exploration, mountain climbing, archeology, botany, geology, and ethnology.

During the early 1930's the Hydrographic Office of the Navy Department made systematic hydrographic surveys and carried on geodetic work in the Aleutian Islands. These expeditions were organized for the purpose of determining the feasibility of establishing air bases on the various islands, and the locating of adequate ship anchorages at various points along the Aleutian chain. The resulting surveys, maps, and reports were of great value in preparing for the military occupation and defense of Alaska after Pearl Harbor.

The Alaska Road Commission carried on many surveying activities in Alaska, principally in connection with road location. One of the largest expeditions of this kind undertaken by the Commission was a survey of a land route for a mall and pack trall from Fairbanks to Council City and Seward Peninsula. Field work on this project was accomplished during the summer of 1906 by civil engineers working under direction of the president of the Alaska Road Commission, Major W. P. Richardson. Reconnaissance surveys were prepared for this route, and furnished valuable information for map compilation.
The Revenue Cutter Service and the Coast Guard each made contributions to geographic Information of Alaska which were utillzed by the Coast and Geodetic Survey in compiling nautical charts, and by the Geological Survey in preparing reconnaissance topographic maps.

Numerous newspaper men, adventurers, explorers, and mountain climbers, have made trips into various parts of the Territory of Alaska. Many of these expeditions were widely publicized and conveyed the impression to the public that a large amount of mapping was accomplished in this manner. Actually, the combined result of most of these so-called exploring expeditions was insignificant as far as usable map information was concerned.

One exception to the unimportance of individual exploration in Alaska was the work of Robert Marshall during the summers of 1929 , 1930 , and 1931, in the headwaters of the Koyukuk River. He prepared drainage maps of the Koyukuk River basin north of the Arctic Circle, from 10,000 to 15,000 square milles in area. Many geographic features were discovered and named on these expeditions. The results were published in report and map form by the Geological Survey in 1934.

$$
\text { RECENT MAPPING (1940-50) }
$$

From 1940 to 1950 more progress was made in surveying and mapping in Alaska than in any other period in the history of the Territory.

Even before our entry into World War II it became increasingly apparent that the strategic position of Alaska would make the area important in a global war. Mapping and charting of the Territory, therefore, received attention by those responsible for national defense as early as 1940. Both reconnaissance and detailed surveys were necessary to determine suitable locations for military airports, as well as to determine problems connected with their construction. The Army Air Forces required navigation charts at different scales to facilitate air travel across the Territory. The Army, concerned with the defense of strateglc areas in Alaska, particularly the land transportation routes, needed maps of both coastal and interior areas, 
and the Navy could not operate effectively in Alaskan waters without hydrographic charts.

Surveying and mapping operations were continued by the Coast and Geodetic Survey and the Geological Survey throughout the war, principally to assist the military services which were at that time rapidly expanding their own facilities for producing military maps and charts. Much was accomplished during this war-time period, particularly in control and mapping at reconnaissance scales. Post-war defense plans, combined with a large scale program designed to develop the economy of Alaska, called for continued surveying and mapping. This work has been continued in a coordinated effort by the U. S. Geological Survey, the Coast and Geodetic Survey, the Corps of Engineers, the Bureau of Land Management, and the Aeronautical Chart Service.

\section{Work of the Coast and Geodetic Survey $(1940-50)$}

Most of the normal operations of the Coast and Geodetic Survey in Alaska were sharply curtailed during the war. Survey ships were assigned to naval operations and personnel were either transferred to the armed services or were used directly on war mapping and charting activities.

One of the first postwar operations undertaken by the Coast and Geodetic Survey was the connection by triangulation of control surveys of the Pacific Coast with those of Alaska, thus establishing a coordinated network of continental triangulation based on the North American Datum for 1927. This work required continuous ares of triangulation from Puget Sound through British Columbia and southeastern Alaska, and thence along the Alaska Highway through the Yukon Territory and the Tanana valley to Fairbanks. From there a connection was made with the earlier arc that extended from Cook Inlet to Broad Pass along the Alaska Railroad. A new arc was established along the Richardson Highway between Big Delta and Valdez, with a crosstie between Gulkana on the highway to Tok Junction on the Tanana River. Another major arc was run from Nenana down the Tanana and Yukon
Rivers to Norton Sound, via the Kaltag-Unalakleet portage. A tie was made to Little Diomede Island in Bering Strait by an arc along the south coast of Seward Peninsula. This work is now being extended north and east along the Arctic Coast to Demarcation Point, the north end of the Alaska-Canada boundary on the 141st meridian.

In southern Alaska another major arc was extended along the south side of the Alaska Peninsula through the Aleutian Islands to Attu Island. This arc is, in turn, connected with the northern work by a network from Iliamna Bay across the base of the Alaska Peninsula to Bristol Bay, thence northward along the coast and up the Kuskokwim River, where a tie is made between Aniak and Holy Cross.

Concurrent with the expanded postwar geodetic work, the Coast and Geodetic Survey also increased hydrographic survey operations, particularly in the Aleutian Islands, Prince William Sound, along the south shore of the Alaska Peninsula, in Bristol Bay, and in the Bering Sea. Modern survey ships assigned to the Alaskan work since the war include the Explorer, Pathfinder, Lester Jones, Pioneer, Patton, Derickson, and the Westdahl. Offshore hydrographic work has been greatly expedited by the use of the electronic position indicator, an adaptation of the war-developed shoran.

Coast and Geodetic Survey operations include the maintenance of existing stations and the establishment of many new tidal stations in the coastal waters of Alaska. Magnetic surveys, which were begun by Professor Davidson in 1867, are being expanded to provide isogonic information for use on aeronautical charts.

Under a joint agreement among the Department of the Army, the Geological Survey, and the Coast and Geodetic Survey, topographic mapping of the Aleutian Islands west of 165 degrees, will be carried on by the Coast and Geodetic Survey in conjunction with nautical charting and geodetic work. These maps are required for military use, and will be published first by the Army Map Service at a scale of 
$1: 25,000$, and later by the Geological Survey for civil use at a scale of $1: 63,360$, as an integral part of the National Topographic Map Series.

Work of the Corps of Engineers (1940-50)

After the early explorations carried on by field parties under the sponsorship of the War Department between 1895 and 1902, little surveying or mapping was accomplished in Alaska by that Department before 1940. The Corps of Engineers requested the Geological Survey to make several detailed surveys in Alaska in connection with the location of proposed Army Air Bases. These included Annette and Yakutat. Early in World War II, the 29th Engineer Battalion, with headquarters in Portland, Oregon, dispatched field parties to Cook Inlet where control surveys were made as part of a training program. These covered several quadrangles which were later compiled by multiplex method from aerial photographs into maps published at a scale of 1:50,000. Several quadrangles were also compiled from photographs of part of Unalaska Island. Numerous other isolated surveying and mapping jobs were performed by the Corps of Engineers during the war, principally in training programs or to assist in construction work.

After the cessation of hostilities plans were formulated for an expanded mapping program in connection with hemispheric defense. Such a program obviously called for greatly expanded activity in Alaska. Although the mapping of Alaska for more than 50 years had been primarily a civilian responsibility under the Geological Survey, priorities established by the General Staff under the postwar defense program required an expansion beyond the capabilities of the Geological Survey. Mapping of extensive areas in western Alaska, including Seward Peninsula, was assigned to the Army Map Service, and work was undertaken during the field season of 1949 to establish control in Seward Peninsula for multiplex mapping of the area at relatively large scales. Upon completion of the Seward Peninsula work Army mapping will be extended to include coastal areas from Norton Sound to Bristol Bay. When completed, this work will be published in a military edition by the Army Map Service, and, as is required, in civilian edition by the Geological Survey at civilian scales.

$\frac{\text { Work of the Aeronautical Chart Service }}{\text { of the Air Force (1941-50) }}$

The Aeronautical Chart Service, or the Map Chart Division as it was originally called, was organized in 1941 and almost immediately began the preparation of several series of charts for planning and operational use. These charts followed the general outline and specifications recommended by the Federal Board of Surveys and Maps in 1929, when a special committee of the Board had studied the subject of aeronautical charting. However, the United States had declared war before the airlanes through the Northwest Territory of Canada and across Alaska were charted. In order to provide the minimum information necessary to compile aeronautical charts, the Aeronautical Chart Service, the First Photographic Group of the Army Air Forces, and the Alaskan Branch of the Geological Survey began work in 1941 on reconnaissance mapping. A new and then-untested method using aerial photographs was employed. This new method was destined to become one of the most important contributions to mapping and charting developed during World War II. Because of the urgent need for pilotage charts covering northwest Canada and Alaska, it was natural that these vast unmapped areas should be the proving ground for the trimetrogon mapping system. The work carried on in Alaska by the Air Forces and the Geological Survey to develop trimetrogon mapping served not only to perfect a new technique in rapid mapping, but also to supply a vast amount of new geographic information covering the unmapped areas in the Territory.

Between 1941, when the first experimental photographic flights were made in Alaska, and 1946, most of Alaska was covered by trimetrogon photography, and charts had been compiled and published. The Aeronautical Chart Service prepared specifications and edited and published the final charts. The First Photographic Group and its successor, the 311th Wing, accomplished the photography and established astronomical positions for control in remote areas throughout 
the Territory. The Geological Survey compiled the base topographic information for the charts, using special techniques and instruments developed for mass production of trimetrogon mapping. Most of the charts of Alaska prepared and published by the Aeronautical Chart Service were at scales of $1: 500,000$ and $1: 1,000,000$. The millionth scale series was completed during the war and the half-million series is still being compiled for the lower priority areas. All existing information from earlier surveys by the Geological Survey, the Coast Survey, and others, supplemented by trimetrogon compllation, was used in the preparation of the aeronautical charts. A maintenance program provides for revision of individual charts as new control and topographic information become available.

Much of the original information compiled from aerial photography for the aeronautical charts of Alaska has been used by the Geological Survey to prepare a revised 1:250,000 scale series covering the entire Territory, which will, when completed, become a part of the National Topographic Map Series. The joint cooperative effort of the Aeronautical Chart Service, photographic units of the Air Force, and the Geological Survey has produced the greatest contribution to the surveying and mapping of Alaska made during the 200 years covered by this report. Alaska's strategic position for the effective use of air power in national defense requires accurate maps and charts. It appears certain, therefore, that the Department of the Air Force will continue to take an active part in photographing Alaska from the air, as an indispensable aid to the preparation of topographic maps and aeronautical charts.

\section{Mapping Activities of the Geological Survey $(1940-50)$}

For 45 years the work of the Geological Survey in Alaska has necessarily been connected with the development of the mining industry, and much of the topographic mapping has been undertaken in areas of potential mineral value. By 1940, nearly one-half of the Territory had been mapped in some manner. A large part of this mapping could be classified as "exploratory reconnaissance", at scales ranging from 4 miles to the inch to 8 miles to the inch. Mapping at larger scales, principally $1: 62,500$, had been accomplished for more than twenty widely separated areas. Most of these surveys covered established mining districts. A considerable portion of the area north of the Brooks Range and east of the Colville River remained unexplored at the beginning of World War II.

In 1941 the Alaskan Branch of the Survey was requested by the Army Air Forces to develop a method for rapid exploratory reconnaissance mapping, for use in compiling aeronautical charts. Alaska, therefore, became a testing laboratory for trimetrogon mapping and a program was started by the Geological Survey, under the auspices of the Army Air Forces (Aeronautical Chart Service), that was ultimately to have a far-reaching effect on the mapping of Alaska and many other unmapped or poorlymapped areas throughout the world.

After the war the Survey continued to use the trimetrogon photography of Alaska, with some refinement of wartime methods, to produce reconnaissance maps of many areas, but because of a growing demand for maps at large scales, ways and means of obtaining singlelens mapping photography were studied. A relatively small amount of this type of photography had been obtained by units of the Air Force and the Navy in Alaska, and no program covering extensive areas was undertaken until 1948. At that time the Navy Department in cooperation with the Geological Survey and other Federal bureaus returned to southeastern Alaska and, with war-trained photographic squadrons, using the most modern equipment available, photographed more than 20,000 square miles, obtaining high-quality aerial photographs suitable for large scale topographic mapping. During the same summer other photographic units of the Navy covered large areas in the Naval Petroleum Reserve No. 4 in northern Alaska. This coverage was required principally by geologists and geophysicists in the exploration for oil within the Reserve.

One squadron, before returning to its Callfornia base in the fall, photographed an area covering the new highway between Anchorage and Tok Junction. 
During the war years the Geological Survey sent few topographic fleld parties to Alaska. Most of the available equipment and personnel were used to prepare maps and aeronautical charts from trimetrogon photography by officecompilation methods. Although this compilation eventually covered most of Alaska, the personnel of the Survey ordinarily engaged in Alaskan mapping devoted much of their effort during the war to preparing charts of foreign areas. After the war the trimetrogon mapping of Alaska was used to compile for republication the standard base map of Alaska, known as "Map E". This map was published in 1947 at a scale of $1: 2,500,000$ and a comparison with the edition of 1939 reveals the great amount of work accomplished in Alaskan reconnaissance mapping during the war.

For some areas in Alaska the "trimet" coverage is also used to complle and revise maps at a scale of $1: 250,000$. A program is planned to cover the entire Territory at that scale, with an estimated completion date for the entire series by the end of 1953 . Immediately after the war, and before single-lens photography became available for photogrammetric mapping, field parties returned to Alaska and carried on mapping work for both civil and military use. Much of this new work was prepared for publication at a scale of 1:62,500, and photo-topographic methods and trimetrogon photography were used to supplement the plane-table surveys made in the field. The area between Anchorage and Fairbanks was given a high priority because it covered the Territory's principal transportation routes. Therefore, several parties were sent to this area to establish horizontal and vertical control for use in aerial photographic mapping. These parties used helicopters to speed up the field work. This was the first time this unique aircraft had been used for surveying operations and its use by the Geological Survey in Alaska has demonstrated its usefulness in transporting surveyors and equipment to remote stations on hlgh mountains. The rate of progress has been increased to such an extent that a crew of six men and two helicopters can control one quadrangle per day (approximately 200 square miles), and a single engineer has established as many as fifty supplemental control points in one day.
Prior to the use of helicopters it took an engineer an entire season to control a quadrangle for standard mile-to-the-inch mapping. Many other surveying organizations throughout the world have followed the Survey's lead and are now using hellcopters to expedite survey operations.

During the summer of 1949 photographic units of the Army Air Forces and the Navy continued photographic mapping operations in Alaska. Navy Squadron VP61, based at Nome, photographed additional areas in Naval Petroleum Reserve No. 4, as well as a large part of Seward Peninsula. Air Force Reconnaissance Group 55, of the 311th Air Division based at Fairbanks, in spite of adverse weather conditions during that summer, photographed more than 30,000 square miles, covering much of the area between Anchorage and Fairbanks, including the Richardson Highway and the Alaska Railroad. This coverage was accomplished to rigid mapping specifications and, in addition, was controlled by shoran, an electronic method of measuring distances accurately from fixed ground stations to the aircraft in flight. Signals from ground stations are recelved in the plane and converted to distance measured in microseconds of time. They can be adjusted and synchronized with vertical mapping photography to compute a geographic position for the opt1cal center of each aerial photograph. If final accuracy tests prove this method satisfactory, it will not only expedite mapping of many areas in Alaska, but will also eliminate the necessity of the very costly arcs of triangulation now being planned for mapping control in Alaska. The Geological Survey has requested the Department of the Air Force to continue this shoran-controlled photography of Alaska in order that standard quadrangle mapping of high priority areas may be completed. In response to this request photographic units of the Air Force covered an additional 20,000 square miles in south central Alaska during the summer season of 1950. A request has also been made for complete photographic coverage of all unmapped areas of Alaska at high altitudes (above 35,000 feet), for use in the preparation and revision of the 1:250,000 scale map series. 
In order to provide elevations for topographic mapping the Geological Survey has investigated several methods being developed by private companies and the military services to provide airborne control. A contract was entered into with a Canadian company with specialized equipment to establish spot elevations over a large area during the summer of 1950. Radar altimetry has been used successfully in Canada to provide spot elevations for the control of aeronautical charts and it is believed if this method is successful it can be used effectively with shoran to provide both horizontal and vertical control for mapping at medium $(1: 63,360)$ and small $(1: 250,000)$ scales. This combination of airborne control methods should be ideal for reconnaissance mapping over large areas in Alaska, particularly north of the Arctic Circle.

The contract radar altimetry project covering an area of approximately 60,000 square miles in central Alaska was completed late in the summer
Preliminary computations indicate that this experimental coverage will provide vertical control of sufficient accuracy for the compilation of medium scale maps with a contour interval of about 100 feet.

Topographic mapping in Alaska accomplished prior to World War $\Pi$ was published in sheets of varying sizes, generally to accomodate the work of one or two seasons or a specific mining area. More than 50 such sheets had been published without an attempt to provide a serles of standard-sized quadrangles. After the war a new map-sheet layout was designed for Alaska, including scales of $1: 24,000,1: 63,360$, and 1:250,000. Alaskan maps now belng published are on standard format and are considered part of the National Topographic Map Series. Sheets originally prepared by the military services will later be published by the U. S. Geological Survey as part of this National Series.

\section{SELECTED BIBLIOGRAPHY}

Abercrombie, W. R., Copper River Exploring Expedition: 56th Cong., 1st sess., S. Doc. $306,1899$.

Baker, Marcus, Geographic Dictionary of Alaska (2d edition, prepared by James McCormick): U. S. Geol. Survey Bull. 299, pp. 7-77, 1906.

Bancroft, H. H., History of Alaska, 1730-1885, pp. 194-220, 510-530, San Francisco, 1886.

Brooks, A. H. , The Geography and Geology of Alaska: U. S. Geol. Survey Prof. Paper 45, pp. 104132, 1906.

Colbert, L. O., Programming Field Operations in Alaska: Coast and Geodetic Survey Jour., vol. 2, pp. 3-7, 1949.

General Land Office, Annual Reports of the Director.

McPherson, J. L., Reconnaissance and Survey for a Land Route from Fairbanks to Council City, Alaska: 59th Cong., 2d sess., S. Doc. 214, 1907.

U. S. Coast and Geodetic Survey, Annual Reports of the Director.

U. S. Geological Survey, Annual Reports of the Director, for 1905 to 1949.

Wickersham, James, A Bibliography of Alaskan Literature 1724 to 1924; Cordova Dally Times Print, pp. 1-37, Cordova, Alaska, 1927. 